\title{
Title:
}

\section{THE PERCEPTION OF WORK IN TOKUGAWA JAPAN: \\ A STUDY OF ISHIDA BAIGAN \\ AND NINOMIYA SONTOKU}

\author{
Eiji Takemura \\ School of Oriental and \\ African Studies, \\ University of London
}

This dissertation is submitted for the degree of Ph.D. 
ProQuest Number: 10731587

All rights reserved

INFORMATION TO ALL USERS

The quality of this reproduction is dependent upon the quality of the copy submitted.

In the unlikely event that the author did not send a complete manuscript and there are missing pages, these will be noted. Also, if material had to be removed, a note will indicate the deletion.

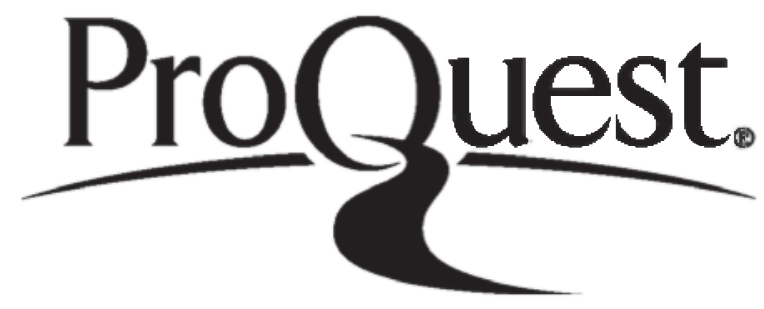

ProQuest 10731587

Published by ProQuest LLC (2017). Copyright of the Dissertation is held by the Author.

All rights reserved.

This work is protected against unauthorized copying under Title 17, United States Code Microform Edition (C) ProQuest LLC.

ProQuest LLC.

789 East Eisenhower Parkway

P.O. Box 1346

Ann Arbor, Ml $48106-1346$ 


\section{Abstract}

The study of work in the Tokugawa period by intellectual historians has revealed the linguistic and ritual ways in which work was ideologically represented during that time. Work, however, is not an activity which belongs only to the realm of ideology; the actual 'form' of work is dictated by economic and technological factors. This study focuses on Ishida Baigan and Ninomiya Sontoku, who both acted as key channels through which ideology and economy were amalgamated, the meaning of work identified and intellectual expression given to it.

Ishida and Ninomiya are often cited as role models used by the late-Meiji and prewar governments to impose self-sacrifice and blind submission onto the people, rather than as media for the social construction of work in the Tokugawa years. Few Japanese scholars specialising in Ishida and Ninomiya are familiar with the theoretical, empirical and anthropological studies of work developing in Western scholarship; attempts have yet to be made to approach the thought of Ishida and Ninomiya from such perspectives, and, as a result, their importance in the social construction of work in the Tokugawa era has not been fully acknowledged.

Neither of the two thinkers advocated passive adaptation to a portional role in society, nor submission to a particular role given by a superior: Ishida argued for a worker's active participation in decision-making in business affairs and for skills to maintain efficiency in the implementation of collective tasks (inter-personal and managerial skills). Ninomiya advocated the management of time, technology and the labour force in pursuing agricultural work. Ishida spoke of work for the benefit of the long-term prosperity of the household; Ninomiya viewed work not only as the means to secure the material prosperity of an individual but as a 'cumulative agency' for the successive betterment of the household for generations to come. In contrast to the accepted view of them as thinkers exclusively in favour of submission and hard labour, they acted as intermediaries through which elements of management and long-term vision were incorporated into the concept of work. 


\section{Contents}

\section{Part I Work in Tokugawa Japan: An overview}

\section{CHAPTER ONE}

Introduction

Objectives

Historiography

Structure

\section{CHAPTER TWO}

The concept of 'work' in Tokugawa Japan

Occupational division and role assignment

The household and role assignment

Economic background to the multi-task concept of work

Work as role-play in Tokugawa Japan

\section{Part II Ishida Baigan}

Introduction to Part II

CHAPTER THREE

Ishida's thought on work and the economy

Ideological background

Ishida's thought: Work as the process of self-cultivation

Ishida's thought: The justification of trading

\section{CHAPTER FOUR}

Skill, management, and workers' initiatives in Ishida's thought

The concept of 'skill' in Ishida's work thought

Retainers' initiatives and subjectivity in work

Religion, political values and socio-economic values in

Ishida's thought

\section{CHAPTER FIVE}

The spread of Ishida's thought on work

The nationwide spread of Shingaku 
The teaching strategy in the later Shingaku movement Alienation from secularity in the later Shingaku movement Shingaku thought in the family precepts of trading houses

\section{Part III Ninomiya Sontoku}

Introduction to Part III

\section{CHAPTER SIX}

The idea of work in the thought of Ninomiya Sontoku

The philosophy of work (1): Virtues of industry and planning

The philosophy of work (2): Concepts of Tendō and Jindō

The philosophy of work (3): Production as shinden kaihatsu

\section{CHAPTER SEVEN}

The shiho programme

The economic setting and the programme

Capital investment, the mobilisation of capital, land, and labour resources

The organisation and training of labour

Technological assistance and transfer

Social welfare and village solidarity

A short summary

\section{CHAPTER EIGHT}

Ninomiya's work thought and the peasants' perception of work:

An analysis

The scope of the perception of work

The ideological interpretation and its impact

Competitive cooperatism

\section{Conclusion}

The idea of work as a force of socio-economic change

The interaction of ideology and economic betterment

The Hōtoku movement from Bakumatsu to Meiji 


\section{Acknowledgements}

During the years spent researching and writing this thesis, I have run up a long list of debts, intellectual and otherwise, to many scholars and friends both here in England and in Japan. At the School of Oriental and African Studies, London, Professors Timothy Barrett, Martina Deuchler and Andrew Gerstle, and Drs. Sugihara Kaoru and John Breen were kind enough to read and comment on various parts of the manuscript in different stages of completion. To Dr. Sugihara Kaoru, my supervisor, go additional thanks for his informed instruction, without which it would have taken much longer for this thesis to take shape.

I benefited also from the comments of numerous scholars at various seminars and conferences at which parts of this thesis were aired. Professors Nakaoka Tetsurō and Nagano Hiroko, and Dr. Frank Dikottor have made invaluable comments at an unofficial postgraduate seminar held at SOAS at a very early stage of the PhD course. Professors Sugihara Shirō and Fujita Teiichirō have kindly read and commented on my early Japanese scripts. I should also mention Drs. Richard Sims and Timothy Screech and other participants in the Centre Seminar of Japan Research Centre (SOAS) in December, 1993, and Professors Sakasai Takahito, Fujii Takashi, and Shoda Kenichirō who attended Nihon Keizai Shisoshi Kenkyukai Seminar held at Rikkyō University in Tokyo in March, 1993, for their useful comments.

During my study leave in Japan for the period 1992-3, I was fortunate to have Professor Saito Osamu of the Institute of Economic Research, Hitotsubashi University, as my advisor. I benefited from his wise counsel, as well as from consultations with Professors Odaka Kōnosuke, Yasumaru Yoshio, Wakita Osamu, 
Ōtō Osamu, Denda Isao, Minamoto Ryōen, Sawai Tōru and Komuro Masamichi, all of whom gave me opportunities for fruitful discussions. Special thanks go to Professor Odaka for his great kindness in sparing countless hours of his precious time for reading and commenting on more than two-thirds of this thesis.

No student's research can proceed far without decent support from good librarians and archivists. Thanks go particularly to Mr. Matsuo Kiminari of Hōtoku Hakubutsukan in Odawara who provided me with access to the huge archives concerning Ninomiya Sontoku held by the institute, and Mr. Niki Yoshikazu who helped me in the reading of the kuzushiji manuscripts of Ninomiya. Miss Kay Tipper copy-edited superbly the entire manuscript, despite the substantial involvement in the text the Japanese words and phrases unfamiliar to her.

I must also record my gratitude to another group of people, without whose varied assistance this thesis would never have been completed. Sanwa Bank Foundation offered research grant at the early stage of this project. Enduring financial support from Takemura Kenichi, my father, is very much appreciated. Finally, the most profound thanks go to my wife, Nobuko, for her support particularly in moments of great crisis. 
Special notes:

Japanese names are listed in native order; surname first, given name second. Japanese names and places are written in roman letters (except 'Ishida Baigan' and 'Ninomiya Sontoku' at their very first appearance). Apart from names and places, Japanese words are written in italics; but the terms in familiar use in this field of study are written in italics only at their first appearance in each chapter. Japanese words are transcribed according to the standard modified Hepburn romanisation.

Square brackets are used in quoted extracts to denote comments and interjections which do not appear in the original text, and also surround original Japanese words in the quotations. 
PART I WORK IN TOKUGAWA JAPAN:

AN OVERVIEW

$-7-$ 


\section{Chapter 1: Introduction}

\section{Objectives}

Recent studies on work in industrial societies have shown that economic activity - even 'work' itself - is not just a matter of the objective character of jobs, pay, market forces or security, but is fundamentally related to people's perception of them. Influential factors here are the values placed on work by society and the identity which people hold in relation to them. [1] These values are, in Patrick Joyce's words, often socially constructed through their intercourse with such elements of society as politics, kinship, and religion, the development of which started well before the industrialising process itself. [2] Such 'cultural values' form shared conceptions about work beliefs and behaviour that are considered desirable within a group or society. Members aspire to these beliefs, and their behaviour at work is influenced by them. This fact directs our attention to the origins of worker's attitude in the industrial age, or, more specifically, to the ways in which the perception of work developed in pre-industrial times.

To understand how people respond to industrial change, it is important to examine what kind of people they were at the beginning of the process, and to take account of continuities as well as new ways of thinking. It is the subtle interplay between 
culture and society, between the social and institutional factors that existed during the pre-industrial period and those that predominated during the industrialising process that decisively affect the way industrial work emerges. [3] Of the former factors, the politico-administerial framework and ethical teachings at the popular level contribute considerably to the construction of work as a concept. While the actual 'form' of work (how people pursue productive and other economic activities) is dictated by the technological changes the production process necessitated, political and ethical frameworks determine the way work comes to be perceived. Because these perceptions are important in determining the standard of discipline and incentive in an industrialising society, they also affect actual economic performance.

This dissertation is concerned with this process of the development of work as a social construct with particular reference to pre-industrial Japan. It explores how work was perceived, conceptualised and diffused in the mid-to-late Edo period (1600-1868), through the examination of the thought of Ishida Baigan (1685-1744) and Ninomiya Sontoku (1787-1856), two of the preeminent thinkers of that era. Both men are worthy of investigation, for they acted as a medium for the social construction of work at that time: neither being alienated from 
the Tokugawa commoners and their form of economic activities. The two thinkers interwove the prevalent ideology and the 'form' of work in the economic reality of Tokugawa society, and identified the 'meaning' of work. [4] Their thought was not confined to the realm of 'intellectual discourse' but was applied to the daily activities of the populace, and had important practical influences on their economic activities.

Ishida was a thinker of agrarian origin who served two merchant houses in Kyōto for nearly three decades. His thought not only expressed the popular ethic in a language originally derived from Neo-Confucianism but also clearly reflected the predominant mode of task implementation, or 'way' of working, in the trading houses of Kyōto. The theoretical importance of his thought lies in its synthesis of Neo-Confucian beliefs and the economic values of thrift, diligence, and frugality. At a more specific level, it amalgamates a crucial element of Confucian teaching - coming to know one's nature (sei) through cultivation - and the everyday work of the populace in the secular world. The idea of viewing work as a process of cultivation was thus conceived, and an ideological foundation established. He was the founder of Sekimon Shingaku, or 'Ishida's school for the learning of the heart', a movement that emerged in 1729 and flourished during the second half of the eighteenth and the early nineteenth 
centuries. The movement prevailed through the establishment of organisational centres called $b \overline{o s h} a$ throughout Japan, as well as through its involvement in the foundation of the family precepts (kakun) of trading houses. Shingaku attracted a considerable popular attendance, and became the largest single ideological group of the time, in terms of practical influence.

Ninomiya's thought reflects the popular ethic in the late Edo period, which emphasised self-development and self-reflection through diligence, economy, and piety. [5] Although he was not affiliated with the Shingaku movement, his philosophy shared its tenor; he argued that work was not just a materialwise activity of production, but an act through which one's spiritual self would be cultivated. Shinden kaihatsu, which he advocated, literally meant the 'development and cultivation of one's heart'. The term suggests a conscious projection of the image of agricultural cultivation into the inner-cultivation of self. Unlike Ishida and other successive Shingaku teachers, Ninomiya did not hold frequent lecture sessions to teach his work thought; nor did he run schools. Instead, he put his thought into practice through 'shiho', the village rehabilitation programme. Shihō comprises economic measures designed to fully activate labour, land, and capital resources in order to realise radical development projects. More importantly, the programme incentivised idling peasant 
producers, and nurtured them as entities capable of work process management and long-term production planning. Elements of management were incorporated into Ninomiya's concept of work, behind which was the idea that such productive activity was not an end in itself but an instrument for one's shinden kaihatsu. Ninomiya's philosophical discourse was thus interwoven with practical advice on village rehabilitation. The Bakumatsu (1854-1867) and the early Meiji (1868-1911) periods saw a rapid spread of Ninomiya's thought in the form of the Hōtoku movement. [6] In short, Ishida and Ninomiya were the channel through which the predominant ideological constructs and forms of work came together, and their views were accepted by people, not merely as an 'ethic' to be observed but as an 'idea of work' that would activate and intensify economic activities, and serve as a means of self-cultivation and fulfilment.

\section{Historiography}

Much research had already been done on both Ishida and Ninomiya by the 1930s, most of which was published in Japanese. In postwar scholarship, however, both thinkers appear as negligible at best, and, at worst, denounceable, for they quickly bring to mind the governmental admonition of hard work in the late Meiji and the prewar periods. The Meiji leaders, realising 
the need for civic edification in their pursuit of modernisation, sought to construct an ideology which compelled people to serve the national cause. [7] Ninomiya, a common man who started out penniless and established himself as an agrarian leader, was a familiar figure to the populace, and thus was ideal for the government to use as a paragon of hard work. He appeared in elementary school textbooks in 1893 and thereafter, and stood in every elementary school playground in the form of a stone statue. The concept of work expressed in the thought of Ninomiya, and in that of Ishida, was integrated into the government ideology where it tended to be degraded into a mere admonitory discourse which functioned as internal psychological constriction for diligence and loyalty.

The increasingly repressive prewar military government of the 1930s set out media restrictions that extended to academic works, but, on the other hand, vigorously encouraged the publication of works on such subjects as loyalty and submission. Ninomiya and Ishida appeared as role models in these prewar academic works where their thought on diligence was translated into selfless devotion, on thrift into self-sacrifice, and piety into blind submission. [8] Such misapplications helped dogmatise their thought and form a one-sided image of them as thinkers advocating sacrifice and submission virtually exclusively; an 
image that this study will prove to be highly misleading.

Despite these biased depictions and the subsequent disregard of the two thinkers, reliable research works do exist, including some published in the restrictive prewar period. Among the most important on Ishida are Ishikawa Ken's Sekimon Shingakushi no Kenky $\bar{u}$ or 'A Study of the History of Sekimon Heart-Learning', and the works of Shibata Minoru, including his edition of Ishida Baigan Zensh $\bar{u}$ or 'The Complete Works of Ishida Baigan'. [9] A chapter by R.N. Bellah, 'Shingaku and its founder, Ishida Baigan' in his Tokugawa Religion (first published in 1957), has been the most influential work in English to date. [10] Bellah argues that Shingaku viewed hard work as an expression of loyalty to one's superiors; the spread of such a valuation of work within society eventually contributing to the development of achievement orientation. Japanese scholars such as Takenaka Yasukazu have also argued for the emergence of work ethic in Ishida's thought in the same vein. [11]

Sasai Shintarō is the editor of the thirty-six volume Ninomiya Sontoku Zensh $\ddot{u}$ (The Complete Works of Ninomiya Sontoku), which consists of Ninomiya's philosophical writings, memoirs, the shihō programme of all the villages in which it was implemented, and records of correspondence during its implementation. [12] With his immense empirical knowledge of 
Ninomiya, Sasai published a substantial essay on Ninomiya in 1935 in which he reconstructed Ninomiya's life and experiences, and dealt with his philosophical discourse on the universe and man's everyday life and work. [13] Sasai was, on the other hand, a leading member of the Hōtoku movement in the prewar period. His written works on Ninomiya are preoccupied. with his discourse on diligence and loyalty. However, his editorial works - including Ninomiya Sontoku Zensh $\bar{u}$ - do not manifest such a tendency, and provide the basis for the study of Ninomiya.

It was not until 1959 when Naramoto Tatsuya published his study on Ninomiya that the prewar image of him was ameliorated at least in part. His study focuses on the centrality of the concept of planning in Ninomiya's thought on the economy. Naramoto paid special attention to the credit system in the shihō programme, and noted that the programme was designed to loan capital, unused or reserved, in accordance with the different needs of individual households and included long-term plans for accumulation. [14] In the meantime, economic historians such as Ōtō, Fukaya and Ōtsuka studied specific shihō programmes with the knowledge of local history. Unpublished materials related to the shihō programme have been collected in Hōtoku Museum in Odawara, although the cataloging of these materials is still in progress. 
So far, few Japanese research works on Ishida and Ninomiya have made their way into English. Works with important historiographical contributions exist in Japanese literature, but they have been made largely inaccessible to non-Japanese speakers. On the other hand, few Japanese scholars specialising in Ishida and Ninomiya, even present day ones, are sensitive to the theoretical, empirical, and anthropological studies of work that have recently developed in Western scholarship; no attempt has been made so far to approach the thought of Ishida and Ninomiya in the light of these recent methodological development, and the importance of the two thinkers in the social construction of work in the Edo period has not been fully acknowledged for this reason.

Furthermore, most of the studies on the two thinkers, including the ones mentioned above, presuppose that the concept of hard work and its justification are central to their thought, as well as to the Japanese concept of work generally. This study will show, instead, that the essence of the thought of Ishida and Ninomiya was to regard work as a process of self-refinement, or, as a means for the cultivation of the worker. Although this has been referred to in the works of Ishikawa Ken, Sakasai Takahito, and in a comment on Ninomiya by Yasumaru Yoshio in their respective studies, it has not been considered as fundamental to 
the emergence of the Japanese perception of work. [15] Hard work alone would not necessarily lead to self-cultivation. In the thought of Ishida and Ninomiya, a wider range of ideas and economic forms was identified as relevant to the meaning of work, including the practice of inter-personal and managerial skills. Self-cultivation acted as a central concept which would motivate workers to enrich the meaning of their work, and would enhance their capacity to handle their social relations.

Significantly, this last point implies the fundamental importance of social relations in the meaning of work. In existing scholarship, work has been understood in terms of an individual worker's action towards a physical object, and cultivation has been assumed to be sought through the interaction between the worker and the object. Work, however, is not merely an act of individuals; nor is it a unitary act. Typically it is an aspect of social relations which involves a division of labour of some kind. As such, it calls for the serious consideration of the effects of the social relations of the Edo period on the development of the perception of work at the most fundamental level of conceptualisation. Ishida was concerned with this aspect of work, and argued for the importance of inter-personal as well as managerial skills in striving for the maximum activation of human resources. Co-ordination and management of labour were 
complementary elements in Ninomiya's organisation of work in his shihō programme. Moreover, human resource management was not his sole concern; the management of such resources as capital, technology, time, and land was emphasised and identified as an intrinsic element of work.

Equally important was Ishida and Ninomiya's valuation of work in relation to the household (ie); the corporate transgenerational entity, seat of the highest moral values in Tokugawa Japan. Ishida was concerned with smooth communication and consensus formation between household members, for these were vital in maintaining the stability of and succession in the trading houses. Skills in consolidating personnel affairs and facilitating information exchange between workers were valued even more than highly specialised individual skills in trading. Ninomiya for his part viewed work not only as the means to secure the material prosperity of an individual but also as a 'cumulative agency' for the successive betterment of the household for generations to come. In his thought, the prosperity of the present members of a household was directly brought about by the industry of their ancestors. Similarly, the descendants' quality of life depended on the work of the present members. Effort was accumulated over generations in order to improve the prosperity of the household. In the thought of Ishida and 
Ninomiya, work was not an individual's act for the benefit of that individual, but an act which upheld the transgenerational merit of the household. In turn, the household members' valuation of work stemmed from this aspiration. Both thinkers regarded work as a process of cultivation, not, however, as a process of attaining individualistic aspirations and goals set by the worker himself; rather, it served to fulfil a 'role' in social and diachronic contexts that cultivated people.

Moreover, virtually no study has taken on board the task of relating the notional construction of work to socio-economic development in the Edo period, and of exploring how the work thought of Ishida and Ninomiya merged with the prevalent form of work. Both the narrow focus on 'hard work' and the understanding of work as an individual's act made it difficult for scholars to relate the thought of Ishida and Ninomiya to the economic and social realities of Tokugawa Japan. This dissertation attempts to fill this gap by relating the thought of Ishida and Ninomiya to the then predominant form of work on the one hand, and by tracing the process of the diffusion of their thought through the populace on the other.

It may be helpful, at this juncture, to comment on the two existing academic approaches related to the study of work in 
Tokugawa Japan - intellectual history and people's history (minshīshi) respectively - in order to locate our approach and level of analysis within the general context of Japanese historiography.

Intellectual historians have largely focused on the development of the most sublime discourses of intellectual elites. For them, Ishida and Ninomiya may not be the figures of prime importance. However, they assimilated, interpreted and amplified the work consciousness of the people; as thinkers with 'active experience' of work in real life, they represented popular work culture, which was deeply embedded in language, consciousness, and behaviour, and gave an intellectual expression to it. In this regard, they are even more important than the great figures of the Tokugawa intelligentsia. In the words of Nakai Nobuhiko, a social and economic historian profoundly versed in popular thought in the Tokugawa period, there are certain 'strata' (soii) in thought; there is 'intellectual thought', which is by nature highly abstract, and there is also thought that is more akin to a representation of popular consciousness. The latter may be alien to sublime discourses of intellectualism, but is of prime importance if one wishes to understand the substructive consciousness of the common people [16], including its implications for work. The thought of Ishida and Ninomiya is, as 
we shall see in this study, preeminently representative of this type of thought.

H.D. Harootunian's work on kokugaku (the nativist school) has dealt extensively with the notion of work (and/or labour) developed within this school. Harootunian argues that the collective pursuit of agricultural cultivation, coupled with practices of economy and thrift, were viewed in kokugaku as a primal act through which the 'founding fathers' of the nation were worshipped and the principle of creation continuously reproduced. [17] While Harootunian's study has made an important contribution to the assessment of kokugaku's ideological origins and its essence, and discusses how the valuation of work as an expression of worship is developed in that context, it views work only as an ideological construct, not as the product of an interplay between social, politico-administerial, and economic factors in Tokugawa society. The study is not primarily concerned with the actual impact of the kokugaku notion of work upon the people's perception of work. Najita Tetsuo's Visions of Virtue in Tokugawa Japan explores the thought of the Kaitokudō scholars. The Kaitokudō, a merchant academy in Ōsaka established by wealthy merchants of the city, consisted of scholars of chonin origin, and stood as the medium through which their 'virtuous' thought and morality were 
expressed. Najita discusses the attempts by the Kaitokudo scholars to formulate an ideological justification of trading and of the merchants' 'public' role as economic management specialists. The focus of his study, however, lies in the merchants' ability to grasp the form and substance of moral and political norms, which was, in Najita's view, on a par with that of the ruling class (samurai). [18] The core of Najita's discussion is 'morality' and the capacity of the merchants to understand and manoeuvre the political economy of Tokugawa society. On the other hand, the prevalent form of work in economic reality was not primarily his concern. It thus remains unclear how popular morality and attitudes towards work were developed among the common people in actual terms. As is the case with Harootunian's work, the actual influence of the thought of Kaitokudo thinkers cannot be ascertained. Both Harootunian and Najita deal with thought that developed close to the people, but they deal with it as sublime 'intellectual thought' of a highly abstract kind developed by sublime thinkers, rather than as thought developed through an interactive process between commoners and popular thinkers, or as the representation of a socially constructed popular consciousness and an expression of the popular attitude towards work.

The term 'popular consciousness' might remind readers of 
the literature on peasant uprisings and disputes in Tokugawa Japan, and of the people's history (minshüshi) approach, which gained currency in the discussion of the history of socio-political consciousness during the Bakumatsu and Meiji periods. Indeed, minsh $\bar{u} s h i$ studies have provided us with significant insights into the customs and mores of the populace. [19] Some researchers were concerned with the emergence of political consciousness among the common people, and traced their socio-political interactions with other people in different status groups. Most of the minshüshi studies of the Edo period concentrate on this element, and are based primarily upon records and manuscripts dealing with village turmoil (murakata sōdō), legal action against domains (kokuso), and peasant uprisings (hyakushō ikki). [20] The primary focus of these studies has been the fusion of popular consciousness and political action at the level of specific events. However, one cannot construct an idea of work prevalent in the everyday life of the people using as a basis particular political steps taken by them on extreme occasions. Studies on customs and mores inform us about the life of the people, but it is necessary to adopt a different approach if one's primary interest is in their thoughts and attitudes towards work. This study will attempt to identify these very thoughts and attitudes, in the hope of widening the horizon of the history of popular consciousness. 


\section{Structure}

This thesis is divided into four parts. Part I (the first two chapters) provides an overview of the Tokugawa concept of work which serves as a general background of the subsequent studies; Part II (Chapters 3 to 5) deals with Ishida, and Part III (Chapters 6 to 8) deals with Ninomiya. These are followed by a conclusion. Altogether this thesis consists of a group of historical studies related to a single topic - work - rather than a genuinely historiographical, consecutive narrative.

Chapter 2 discusses the main intellectual and economic apparatus within which work developed as a conceptual construct. It suggests that work in Tokugawa Japan was perceived in terms of 'role-play' within a particular collective entity such as the household, the village, or the state. It was not an individual activity based on a single skill speciality. With the exception of a few highly specialised artisanal tasks, work was seen as an activity that involved plural tasks.

Part II is a study of Ishida Baigan. Chapter 3 describes the ideological background of Ishida's thought, and discusses his idea of cultivation and the means of attaining it. A distinct feature of the 'method' of cultivation in Ishida's thought lies in his emphasis on commitment to or 'immersion' in work, rather than in the 
pursuit of sublime Neo-Confucian practices for attainment. One's intensive pursuit of a daily task, rather than investigation or meditation, constituted the main means of cultivation.

Chapter 4 explores particular elements of Ishida's discourse as economic thought. Referring to such economic concepts as 'skill', 'management', and 'work initiative', it clarifies the sort of skill referred to in his thought, and the way in which this affected the concept of work. Ishida did not perceive work merely as an act of the individual but as an act which involved social relations, and he argued for the indispensability of managerial and inter-personal skills in the carrying out of collective work in merchant household businesses. Individuals in the household were not only to supply labour but to join in the managerial and business decision-making processes. Accordingly, 'cultivation' in his thought was not to be sought only through individual labour the interactive process between worker and object - but also through one's participation in business management, and the practice of skills which could enhance the performance of other workers.

As stated earlier, Ishida's students set up Shingaku academic centres throughout Japan. They were also involved in the formation of family precepts of trading houses. Shingaku did not remain in the realm of intellectual discourse but spread through 
the actual work processes of the populace. Chapter 5 examines the process of diffusion of Ishida's thought and the extent of its practical influence.

Part III is a study of Ninomiya Sontoku. After a brief introduction sketching his background, Chapter 6 investigates the idea of work expressed in his philosophical writings. Ninomiya viewed agricultural work as a means through which a peasant could contribute to the succession of his household, and cumulatively raise this ideological entity to the highest moral and economic level. Moreover, one's intensive involvement in agricultural activities was directly related to the cultivation of humanity: the cultivation of land brought about the cultivation of the human heart, and vice versa. It was, however, not merely the investment of manpower that cultivated human beings. Ninomiya was concerned with management of time, labour, and other resources. Cultivation was sought through work, but this was accompanied by careful planning and management.

The study of work thought expressed in practical work programme may sometimes enhance a fuller understanding of the idea of work. The shihō programme was a comprehensive package of economic measures for village rehabilitation, designed and organised by Ninomiya. It contained measures which provided peasants with a specific framework of economic 
activities which had the effect of reshaping and institutionalising the structure of peasant work.

Chapter 8 consolidates the main elements found in the studies of both Ninomiya's thought and his shihō programme. Resource management and planning were integral parts of Ninomiya's idea of work. The notion of a continuous and cumulative amelioration through future generations was also vigorously encouraged. The idea of the stable succession of the household and the village was at the core of his thought.

Collective efficiency was of great importance to Ninomiya, but he encouraged neither a 'selfless devotion' to collectivity nor an individualistic approach to work. Rather, he nurtured the idea of individual initiative within the framework of the household or cooperative entity (i.e., the village), and this initiative was to involve those qualities of planning and coordination by which he set such store. Ninomiya's thought should be seen as evidence of the growing recognition in Tokugawa Japan of the importance of individual drive of the promotion of efficient coordination and production management.

The conclusion brings together the main findings of the thought of Ishida and Ninomiya, and locates them in the general context of the development of the Japanese perception of work. Both thinkers succeeded in gathering the undercurrents of the 
attitude to work of a largely inarticulate populace in the mid-to-late Edo period, cross-fertilising them with the prevalent ideology, and passing a concrete idea of work back to that populace. In other words, they acted as key channels of interaction between ideology and society.

Neither thinker solely advocated hard work; nor did they simply teach moral and ethical virtues. Commoners were nurtured by them as able entities in efficiently managing the economic activities of their own, perceiving the long-term benefits for the individual, the household, and society, and identifying the meaning of work for the enrichment of their social and economic life. The two thinkers widened the people's perception of work, and, at the same time, cultivated their attitude towards and capacity for work. The impact made by Ishida and Ninomiya, and the responses engendered by their thinking, on socio-economic change in Tokugawa Japan can thus scarcely be overestimated. 


\section{Chapter 2: The concept of 'work' in Tokugawa Japan}

Recent historiographical and quantitative studies of the Tokugawa economy have revealed the centrality of market forces in society, the growth of market-oriented institutions in urban areas, and their penetration into the rural economy in the second half of the Tokugawa period. The growth of the market in cities and the flourishing of proto-industry in rural areas made economic factors, as distinct from political, social, and cultural ones, a dominant element of Tokugawa society. By this time, society had become a predominantly 'economic' one, where most members of society behaved largely in accordance with economic rationale. [1] Such pre-industrial economic development that occurred in this era helped Japan's relatively smooth industrial transformation in the subsequent period of economic modernisation.

Surprisingly little, however, has so far been done on the understanding of work in pre-industrial Japan, in spite of the existence of a sizeable amount of literature on the labour history of modern Japan. [2] Several studies by intellectual historians have revealed the linguistic and ritual ways in which work was represented at the time [3], but few have been successful in accounting for how the intellectual notion of work was developed 
in relation to the actual form that work took (how people pursued work) in Tokugawa society.

What was actually considered 'work', conceptually or otherwise, in Tokugawa Japan? This chapter seeks to provide a general picture of the concept of work in this period, by looking at linguistic representations of work, and by examining relevant secondary literature on linguistic, economic and social history. In the next section we examine the impact of political and institutional foundations and the dominant social relations within Tokugawa society on the construction of work as a concept; each status group - samurai, peasants, artisans, and merchants - had a certain assigned role, which was largely responsible for defining the nature and scope of the perception of work. This will be followed by a discussion of the influence of the strengthening of household ties - which took place in this period - on work, and argues that the household and the village further strengthened the importance of role assignment. The third section argues that this role assignment was reinforced, rather than checked, by economic development. It discusses the relationships between the system of role-playing and economic development in more general terms, and suggests that the concept of role-playing acted as a powerful tool which shaped the perception of work under economic change. 
Occupational division and role assignment

Social anthropology of work reminds us that work takes its organisation and meaning from other non-economic social institutions, and its meanings vary according to the predominant societal values, beliefs, and institutions of the time. [4] Patrick Joyce, the author of The Historical Meanings of Work, argues that work is a 'cultural' activity, in the social construction of which 'non-economic' elements play a critical role. In contrast to the development of the idea of 'work in general' in the late nineteenth century which constituted a clear demarcation of work from other social activities and institutions, recent studies of work have helped reveal the links between productive activity and other social spheres (social structures) such as kinship, religion, and the politics, in the context of Western historical experience. [5] How does work in Tokugawa Japan look in this light?

In the contemporary Japanese language, the term shigoto (仕事) is generally used to translate the English term 'work', while rōdo (労樹) corresponds to 'labour'. Work and labour were both translated as shigoto for a noun, and hataraku (働<) for a verb in Hepburn's Japanese-English and English-Japanese dictionaries of 1867 and 1872. [6] Neither of these translations, however, satisfactorily represents the concept of work in the Edo period. In fact, work was conveyed by such words as shokubun (職分), 
tenshoku (天睵), and kagyo (家業).Sugiwai (すぎわひ、生業), and nariwai (なりわひ、産業) were also in frequent use. Among the second group of words, sugiwai appears in the JapanesePortuguese dictionary of 1603 , and translated into Portuguese as the word representing productive and other activities to gain the means of living. [7] The word seems to have been used without major change in its meaning during the early part of the Tokugawa period. [8] From the second-half of the seventeenth century onwards, however, the word also began to represent also the activities not directly linked with the economy, such as priestly orders. [9] The word nariwai appeared at a much earlier time than sugiwai and was already in use in the eighth century, mainly representing agricultural production as well as the crops produced. [10] In the Edo period, however, nariwai began to represent the various activities carried out to gain a living, and was often used almost synonymously with the word sugiwai. In fact, the distinction between these two words became obscure, and they were used interchangeably; in Hodō Tsūkan, a series volume of popular literature (dangibon) in the mid-Edo period, for instance, 産業 was read as nariwai, while the same word was read as sugiwai in a "learning text" compiled by the Sugawara family, a Jorruri school. "生活" was read as nariwai in Nansō Satomi Hakkenden, a work written by Takizawa Bakin in the late Edo period. [11] 産業 
- read as sangyo - became a word in common use in contemporary Japan, usually referring to industry as, for example, the automobile industry (jidōsha sangyō) or the distribution industry (ryūtsü sangyō). [12]

The words examined above represent work as the means through which the individual or the household to which that individual belongs gains economic benefit. On the other hand, the first group of words introduced earlier were far less clearly 'economic' than those in the second group, and were closely related to the politico-administerial and institutional frameworks and the ethical teachings prevalent in the Tokugawa period. Words such as shokubun and tenshoku, for instance, were sanctioned in part by shi nō kō shō, the Tokugawa social status groupings stratified according to the nature of the occupations of samurai, peasants, artisans, and merchants. Shokubun was the term in frequent use in the Edo period, literally meaning one's occupation or trade (shoku) fulfilling an allotted part (bun) in society. [13] According to Kaibara Gakken (1625-1702), the pursuit of 'shokubun means, for instance, a bow craftsman crafting bow and arrow, $\ldots$ an artist painting pictures, ... (and) an emperor as a deligate of Heaven blessing people, administering justice, and offering comfort to people .. Samurai, peasants, artisans, and merchants shall be concerned with this principle, and 
be diligent in fulfilling one's own shokubun'. [14] Shokubun meant, in other words, a portion of social role assigned to each. [15] In the words of Muro Kyüsō (1658-1734), a Neo-Confucian thinker, the pursuit of the occupational assignments of $n \bar{o} k \bar{o}$ sho (peasants, artisans, and merchants) was to meet the necessities and shortcomings of society (tenka no fusoku o oginai, tenka no yo o totonou). [16] Miyauchi Yoshinaga (1798-1843), a pupil of Hirata kokugaku in the late Edo period, compares the status groups and the occupations assigned to each of them to the parts of the body and their functions. The ideological springboards of individual thinkers varied, but they share a similar view of the functional indispensability of work to each status group. [17] Samurai, peasants, artisans, and merchants were ranked in this order in Tokugawa society, but the assigned work of each was considered as important a role to each other.

Tenshoku also referred to a role in society, but one that was laid down and guided by tendō (天道), the Heavenly Way. All tasks were sanctioned in Heaven to be fulfilled by people in each status group, in order that social relations should be formed according to 'Heaven's intention'. [18] Thus, work in Tokugawa Japan constituted a role assigned to a particular status group in a varied social context; the constituent parts of this role, or the tasks actually involved, were not specific. 
Although this discussion has only referred to linguistic representations of work in the Edo period, it nevertheless gives an idea of how work as a conceptual construct existed in Tokugawa Japan. Work was seen not only as productive action, but as an act whereby workers formed social relations. An important linguistic feature of work in the Edo period lies - as represented in the second group of words - in the obscure distinction between the productive activity of the individual and the notion of 'role-playing'. Both shokubun and tenshoku assumed that all existing occupations were complementary activities in the formation of social relations, and were, at least in theory, activities of equal importance.

Arguably, the demarcation of shi $n \bar{o} k \bar{o}$ sho has contributed to the development of the notion of work as 'social role'. But this broad definition of role assignment was refined and further strengthened by the prevalence of the concept of yaku (役), as demonstrated by, among others, Bitō Masahide, an historian specialising in the politico-intellectual history of Tokugawa Japan. [19] The term yaku originally referred to the use of a person's labour, although it began to be used to mean various forms of 'service' to the domainal lord by the sixteenth century. [20] Bito argues that in the Edo period it came to represent one's 'role' in society and the assumption of responsibility attached to that role; 
its meaning was no longer confined to the taking on of a particular task or labour. [21] A samurai's yaku was not confined to his commitment to possible military service. As Ogyū Sorai points out, '[a samurai's] nature is a military man, but he must be a master of people to rule the state; to be an administrative officer means to be a man of court rank [who is entitled to rule]'. [22] The samurai's yaku included, in other words, various political and administrative duties. A samurai's service to his lord was called $h \bar{o} k \bar{o}$, and he received a salary ( $g o^{\prime} o n$ ) in return; the feudal lord-vassal relationship of the medieval age remained in Tokugawa Japan, but service was pursued as a national 'public' duty rather than as a service in a private lord-vassal context. [23] Peasants' yaku often included various types of labour needed for the development of infrastructures such as roads and river banks, and their maintenance and improvement. The direct contribution of a labour force was regarded as corresponding to the payment of annual dues (nengu), usually in the form of rice, and such a contribution was often rewarded by a reduction in these dues. [24] In other words, peasants' yaku could be met through various means (tasks); it was not an activity specific to a particular task or skill. The transformation in the use of the term yaku, as pointed out by Bitō, was a product of the nature of Tokugawa work as described above, in which the tasks involved were plural; in turn, 
this transformation was propitious for accommodating and further legitimising work as role-play in its own line of conception. Shi $n \bar{o} k \bar{o} s h \bar{o}$, the status groupings - stratified according to the nature of the occupation of each - would not have sufficiently justified work which was multi-task in nature. The concept of yaku could justify work as role-play without task specificity, as a 'unit of responsibility' which included varied tasks.

Asao Naohiro, an intellectual historian of Tokugawa Japan, criticised Bitō's definition of yaku for regarding it as a social role nonetheless considering that role as the one to be fulfilled by individual members of society; yaku was, in Asao's view, the public role to be pursued by the people in each status group collectively; yaku existed as a public or social role, running through the entire spectrum of social relations, and that the individual workers (or 'labouring subjects') did not exist in the theory of yaku. [25] Whichever stance one takes, this debate on yaku defines work not as a particular task but as a social responsibility. The strong socio-political formation of collective social entities (which effectively corresponded to the Edo status groups of shi $n \bar{o} k \bar{o} s h \bar{o}$ ) ensured that each group would meet that responsibility. [26]

Mizumoto Kunihiko reveals that the concept of yaku was 'transplanted' into village work; the term for 'public 
responsibility' (kōgi no yaku) was used almost synonymously with the term for 'tasks and duties of the village' (mura yaku kinshi), which suggests the merging of the social (or public) responsibility of yaku with village tasks. [27] Furthermore, this study provides us with historiographical evidence of the prevalence of the $y a k u$ concept and the notion of role-play in Tokugawa villages; which also gives authenticity to conceptual studies of yaku by Bitō, Asao, and other intellectual historians.

What happened to the concept of yaku in the eighteenth and nineteenth centuries when the household (ie) became the dominant unit of agricultural production as well as socio-political organisation? No study has explicitly pointed out the possibility that the concept of yaku was transplanted into ie, but there are works which effectively suggest this. Ōtō Osamu's argument on the Tokugawa social strata and the concept of $i e$, for instance, actually shows that the concept of social role was injected into the concept of $i e$; the role was, in his words, institutionally 'attached' to the household. From the late seventeenth century on, this amalgamated concept spread within the emerging small-scale peasant economy. [28]

The household and role assignment

The household and the village both acted as the basic 
economic, social and administrative units of the Tokugawa social order. The notion of role assignment was further strengthened also by these two key social institutions of the Tokugawa period; the household in particular was responsible for linking the idea of role assignment to actual tasks.

Nakane Chie's classic study on the Japanese household concisely describes that entity and the concept attached to it. The Japanese household was a social institution which aimed at its own successive continuation. Economically, the household formed the productive and managerial unit for agricultural and other activities in the eighteenth and nineteenth centuries. Conceptually, it was recognised as the perpetual entity of lineal continuity from the ancestors to the unborn members of the household. It was the medium through which the household members identified themselves with this lineage. The succession of the household was often more important than the welfare maximisation of the present members of the entity. Evidence suggests that the household was a social institution capable of picking a talented heir. Adoption was commonly practised to find the best successor; and a close kinship tie could be dissolved if one's performance of duties and obligations were found to be unsatisfactory. [29]

Nakane perceives the Japanese household as an entity embracing families even outside the kinship relations, a large 
family system that includes "quasi-kin" families within certain territorial boundaries, namely, the villages. Recent socioeconomic historiography, however, shows that each family unit possessed a clearer demarcation within the context of the household than Nakane had suggested. Saitō Osamu, for instance, argues that the Japanese household followed neither the simple household system nor the joint household system. It may best be termed a "stem" system in which the constituent families and their members joined and parted elastically according to, for instance, changes in economic demand. [30] An important feature of the Japanese household has been brought to light here through economic historiographical and demographic research work; it was the smaller-scale family units, not the joint families, that emerged in Tokugawa villages as 'households'.

The meaning of kagyo, another key word which represented work in Tokugawa Japan, needs to be examined here. It literally means 'household work', but it originally referred to speciality occupations pursued by families in possession of a particular skill, i.e., medical and legal skills, in the eighth and ninth centuries. [31] The word also represented the 'property of the household' in the era of Heian, as it appears in Shoku Nihongi of 967. [32] In the Kamakura (1185 or 1192-1333) and Muromachi (1338-1568) eras, kagyō began to represent specific skills to be inherited by the 
members of the household, particularly the skills and techniques inherent in artistic, artisanal, and samurai professions. [33] In the Edo period, however, the use of kagyo was no longer confined to the description of a certain skill or profession; work of the household in any occupational group, including agriculture and trading, had come to be identified as kagyō. Hiraishi Naoaki argues that the concept of kagy $\bar{o}$ developed in Tokugawa society was a product of the 'inter-permeation' of the concepts of sugiwai and shokubun. As we saw, sugiwai meant economic activity, while shokubun referred to an assigned role. According to Hiraishi, these two notions were incorporated into the context of $i e$ (the household), and formed the concept of kagyo, in that work was recognised as role-play as well as economic production for the sake of the prosperity of the household. [34]

Further examination is necessary to ascertain whether the two concepts have in fact 'permeated' to each other. Evidence shows, however, that the word kagyo was used almost synonymously with such words as shokubun and tenshoku, as is apparent in the following words from Ishida Baigan:

'Hasn't one's stable life been actualised by one's own diligence in pursuing kagyō? Those who are not aware of their own shokubun are inferior even to beasts . . . Merchants not being aware of their own shokubun will ruin the household which they are delegated by their ancestors to succeed.' [35] 
The use of the word kagyo is interchangeable here with shokubun, and demonstrates the equal importance of role-play designed to preserve the well-being of the household to shokubun which constitutes the social process. One could assert that this was due to the influence of the ideology developed in the early Edo period, the ideology - as manifested in such words as shokubun and tenshoku - that recognised the work of each status group as complementary to one another in constituting the social process; the contribution of each member of the household was viewed as being just as indispensable in preserving and continuing the household as was the pursuit of shokubun in fulfilling the necessities of social welfare. The use of the word kagyo was 'universalised' for this reason, regardless of the type of skill or skill-level inherent in household work. The concept of $i e$ suited this notional development of role-play.

The 'core' of the household consisted of kach $\bar{o}$ (the household head) and his wife. It would be wrong to assume that kacho, as the leader of the household, was a patriarchal, omnipotent figure:

'Succession of the headship of the household means that he is entitled to pursue a care-taking duty of the ancestral paddies and fields, household belongings, and mountains. He shall invest every effort to maintain these ancestral holdings, shall always be keen to care ...' [36] 
Here he is recognised as 'delegated personnel' with responsibility for the successive continuation of the household. $\mathrm{He}$ was a person who 'temporarily occupied' the position or role of leading the household's lineal continuation. If he was found to be incompetent in that role, he was often pressed to resign by the village yoriai (the highest decision-making body of a village), kin group, and the main house (honke). [37] Thus, the headship was more a household role than one of patriarchal leadership. The village social order monitored the efficiency of the household head in carrying out household duties, and saw that appropriate practical considerations were taken into account.

In other societies, also, the household was often the basic economic unit within which work was carried out in the pre-industrial era. Studies on the English rural economy in the sixteenth and seventeenth centuries, for instance, suggest that most of the tasks - including wage-earning activities - were organised and carried out by individual households. Members of the household were allocated various tasks from garden digging, hoeing, harvesting to so-called domestic work. [38] However, such economic activities do not appear to have helped develop the notion of an assigned role. The household does not appear to have played a critical role in the conceptual construction of work in English society of the pre-industrial period. 
Economic background to the multi-task concept of work

One of the most important factors which gave rise to this emphasis on role-playing in Tokugawa Japan was in fact an economic one. In Tokugawa society, the agricultural household was supposed to be primarily concerned with rice production. In reality, however, the household often could not maintain its subsistence through rice production alone. Its involvement in additional activities such as cotton and tobacco growing, charcoal and paper making was indispensable. [39] The pursuit of these extra tasks $(y \circ g y \bar{o})$ began to appear in the seventeenth century, and became widespread in the eighteenth century. [40] One of the Bakufu surveys, conducted in 1819 in a village of the Province of Shimotsuke, shows that only fourteen households out of eighty-six were not involved in any yogyo; that is to say, 84 per cent of households were engaged in non-rice production. [41] Both central and domainal governments attempted to restrict extra activities through written orders. But, at the same time, they often gave tacit approval of them. Eventually, domainal governments came to encourage these activities in the name of tokusan (special local production), for both revenue and 'foreign' exchange earning purposes. [42] Peasants thus became officially involved in various economic activities, and this situation was responsible, in Fukaya's 
view, for the multi-task nature of work in rural households in the mid-to-late Edo period. [43]

Japanese farming methods and technology continued to develop within the framework of the peasant household economy. The household mainly used family labour, and retained its dependence on the less task-specific, labour-intensive form of work with an emphasis on coordination and management, even in the nineteenth century. There was little evidence of proletarianisation, hence the dependence on skill-specific day labourers.

The development of these additional activities $(y \circ g y \bar{o})$ in rural settings increasingly encouraged the development of cottage industry, or proto-industry, in the second half of the eighteenth century. Unlike pre-industrial England, the Japanese economy did not become rapidly urbanised. Instead, it went through a transformation from urban-based to rural-based industrial development. [44] While the urban population declined, some rural areas developed into centres of handicraft production. Industries ranged from cotton spinning and weaving to saké brewing and paper making, although only a few regions were engaged in such skilled crafts as silk production. The Japanese case was clearly different from that of the English; while rural industries grew, this did not involve a departure from agricultural 
- more particularly, rice - production. Instead, industrial work was carried out in the form of by-employment by the members of the agricultural household, as part of the pursuit of yogyō. Thus the distinction between agricultural work and industrial work became blurred. [45] Such commercialised agriculture as cocoon production was closely linked to silk-reeling, and both of these were classified as 'extra-agricultural work pursued during slack seasons' (nōkan yogyō). Some commercial and transport activities were also classified as nōkan yogyō, and it was this type of proto-industrial work, rather than the work by skilled artisans, that supported Japan's proto-industrialisation in the second half of the eighteenth and the first half of the nineteenth centuries. [46]

Of course, much of these proto-industrial developments were initially dependent on the superior technology and artisanal skill available in large cities such as Ōsaka and Edo. From the second half of the eighteenth century on, however, traditional centres of production and commerce, particularly the Kinai region (centred around Kyōto and Ōsaka), lost their competitiveness due largely to the wage increases of urban skilled workers. As a result, merchants and artisans went back to rural areas to build their businesses, taking advantage of the availability of cheap labour and the more reliable food supply. These rural areas gradually accumulated capital as well as technology, and formed 
proto-industrial areas. [47] Agricultural and proto-industrial tasks thus co-existed in one production unit (the household).

The implications of this kind of economic development are obvious. First, the rural household took on various types of work. Members of the household were engaged in more than one line of business, and often each member was involved in plural tasks. In this work environment, it was not appropriate to attribute the essential constituent of work to one line of business or its specificity. A concept of work which could accommodate the diversity of tasks - similar to kagyo (household business) - was needed. Second, once the conceptualisation of work of this nature emerged, it necessarily affected the perception of work; the activity had come to be perceived as multi-task, rather than as single-task. Whether or not workers with multi-tasks could perform better than those with a single-task would depend on specific economic circumstances. In the case of Tokugawa economic development, a multi-task pattern of work was better suited to the prevailing economic conditions. Third, the multi-task pattern of work helped emphasise the point of role-playing; without task specificity, emphasis on role was an effective way of making the members of the household understand what was expected when work was required. They simply had to identify and play a role, taking into account both the assigned role and the 
specific economic circumstances. Finally, this requirement implied that the content of the role in question was actually not assigned. Rather, it varied according to demand, which differed from one season to another; it also varied according to the type of extra tasks pursued. It was expected that the role would be 'played', regardless of the content of it. Role-playing without task specificity characterised the nature of work in Tokugawa Japan, and also formed the basis for the conceptual development of work.

\section{Work as role-play in Tokugawa Japan}

The lack of specificity in task and function is, according to Herbert Applebaum, one of the features of work in non-market societies. He argues that the presence of division of labour based on the breakdown of tasks and functions is the characteristic of industrial and market societies, whereas there is only a simple division of labour in non-market societies, involving basic cooperation and obligations of family units. [48] Work is intimately linked to all other social institutions such as kinship, politics, and religion in non-market societies, and is thoroughly embedded in the total cultural fabric. Work is directed to fulfil subsistence requirements, and is carried out for the sole purpose of meeting the needs of one's family or kinship group. A sense of competition in work is rare. Work relations are based on kinship, 
and the exchange of work or goods is based on reciprocity. There is little evidence of the existence of a distinct linguistic representation of work, because the productive activity is not separated from, or a dominant phase of, the social process. [49]

Work in Tokugawa Japan appears to correspond to Applebaum's description of work in a non-market society in at least two respects. First, task specificity has often been blurred by the multi-task nature of work, which may allude to the lack of task specificity. Second, the concept of role-playing rejects the clear-cut separation of economic activities from social relations; instead, it incorporates them into social relations.

There are, however, good grounds for arguing that the case of Tokugawa Japan does not fit into Applebaum's scheme. First, there is no doubt that task specificity was well recognised, notwithstanding the fact that people were engaged in plural tasks. Commodity production was widespread, and competition was present. Economic activities were integrated into the national, or at least provincial, economic fabric. Family labour was allocated in response to market demand, and additional labour, often from outside the kin-relation, was hired whenever necessary. [50]

But, in spite of these market developments, it was often advantageous in the Tokugawa economic environment to possess plural skills and take on plural tasks to produce economic results, 
as the peasants have demonstrated through the pursuit of extra tasks $(y o g y \bar{o})$. The nature of work in Tokugawa Japan, and the concept which developed concurrently with it, was a product of the presence of a combination of various tasks, not of the lack of task specificity.

Second, economic activities were clearly separated from activities in other spheres of society. Although festivals affiliated with religion were linked with seasonal regularities in the agricultural cycle, and agricultural work was interspersed with religious breaks [51], this does not imply that work was inseparable from them. Moreover, work was conceptually discernible, as was shown through linguistic representation, and was not embedded in the total social and institutional fabric, unlike productive activity in most of non-market cultures.

Third, the concept of role-play should be seen as an attempt to promote, rather than to hinder, the understanding of the importance of economic rationale for the meaning of work. Under the framework of the Tokugawa social order, considerations of economic rationale had to be incorporated into the more general and strongly socio-political terms of role-playing. But this concept allowed the members of the peasant (or merchant) household to identify their economic activities with their role in society. The clear-cut separation of economic 
activities from social relations would have denied them this opportunity: and it would have limited the range of incentives and justifications of work to a narrowly defined economic gain. Instead, the concept of role-play underpinned the idea that the greater one's economic performance, the greater role one was considered to have played in society.

It is possible to view society in the second half of the Edo period as a 'transitional' or 'mixed' one, as moving from a non-market to a market society. Applebaum employs such terms to define the nature of the closing stage of pre-industrial society, in order to understand the nature of work in such a society. The 'mixed' society typifies, in his view, an uneven and discontinuous social process which is frequently accompanied by resistance to changes affecting the social relations of non-market societies; it is often a painful adjustment and adaptation to a new way. Workers feel that they have no control over the tools and technology needed to perform work, and find that the only way to participate in the production process is to earn the means of living through selling their ability to others as a commodity. [52]

This was hardly the case in Tokugawa Japan. While Tokugawa society did go through "a painful adjustment and adaptation to a new way", particularly in the years of Bakumatsu, peasants were by and large willing to accept changes in their lines 
of business, their tasks and the technology of a specific task. They were far more concerned about the growing socio-economic stratification within the village, and, to some extent, the apparent inability of the Tokugawa regime to cope with forces of economic change. [53] Although people in Tokugawa society knew little about the impact of mechanisation, the society in which the concept of work was developed was undoubtedly the one where economic competition and market-orientation were prevailing.

An inquiry has been made in this chapter into linguistic representations of work, and the social, politico-administerial, and economic factors which contributed to the conceptualisation of work as it appeared in linguistic representations. It may be argued that work was constructed in the mid-to-late Edo period as a role to be played by individuals in such contexts as the household, the village, and society, where the tasks involved were variable. Work takes its meaning from economic as well as non-economic factors, but it clearly was a separate activity, discernible from other spheres of society.

Such findings are intended to serve as a general background for the more detailed study of work to be conducted in the following chapters. The thought of Ishida Baigan and Ninomiya Sontoku, which, arguably, was influential in shaping and 
institutionalising the idea of work of the populace in the mid-to-late Edo period, was in part a product of the socially constructed concept of work; they turned to the social and ideological teachings of the day to identify the meaning of work, and their ideas were expressed in a language derived from the religious teachings of the time, particularly Confucianism. In turn, their thought was not preoccupied with ethical and religious teachings but involved profound consideration of the elements of economics.

The thought of Ishida, as a representative of the eighteenth century Tokugawa merchants in the Kinai region, will be examined in the next three chapters. The thought of Ninomiya will be studied as an example of the agrarian work thought that had developed in the Kantō region by the first half of the nineteenth century; thought which not only reflected the prevailing form of agrarian work but intensified and conceptualised it. 


\section{PART II ISHIDA BAIGAN}

$-54-$ 


\section{Introduction to Part II}

Ishida Baigan was born in a small farming village in the Province of Tanba, north of Kyōto. He was the second son of the Ishida family, a peasant household in the village of Higashi Agata, and spent most of his childhood, up to the age of eleven, in a rural environment. He was in no way highborn or rich, and, as is quite usual for a man of low birth, very little is known about his youth. Yet the outline of his early days and subsequent life course can be traced from retrospective accounts made by Ishida himself in his Tohi-Mondō ('City and Country Dialogue'), the master account, and the memoirs later compiled by his pupil. Ishida was the son of a farming family, but he spent most of his lifetime in urban surroundings. It was not uncommon for the second and third sons of Tokugawa village families to be sent as apprentices (detchi) to the cities, to make some provision for their lives. Ishida, following this custom, was sent to a trading house in Kyōto when he was eleven. Although he was forced back to his family when he was fifteen because of the bankruptcy of the trading house he served, he was sent to another one in Kyōto, the Kuroyanagi family, when he was twenty-three, where he served for more than twenty years. In total, he spent twenty-eight years as a merchant in Kyôto, and he continued to live in the city until his death in 1744. 
Neither of the two trading houses Ishida served was related to, or had close ties with, his family. But, even for an apprentice from an unknown family outside the kinship network, one could expect a gradual promotion in Tokugawa trading houses.

Recruited at the age of ten or so, one usually served an apprenticeship of ten years or thereabouts. If one's performance was deemed sufficiently sound, then one was promoted to 'clerk' or 'retainer' (tedai) in one's late teens. A clerk could occupy an important position in the house, and could eventually establish himself as an independent manager of a branch house if he was sufficiently gifted and his services were well recognised in the household. [1] Ishida was expected to follow this path, but the unfortunate experience of his early days prevented him from establishing himself as a merchant. The bankruptcy of the trading house he served in his youth left an 'indelible stain' on his career, although the incident could hardly be seen as attributable to the services performed by Ishida himself. He became a chief clerk (bantō) of the Kuroyanagi family in his late thirties, but the head of the household neglected to confer the headship of a branch house (noren wake) on him, a crucial step if a shop clerk were to set up in business on his own.

Thus, one could hardly argue that Ishida was hugely successful in trading. On the other hand, his career as a merchant 
was contributory in establishing him as a popular thinker: He was never removed from the economic and social realities of the Tokugawa trading houses, and with his knowledge and experience of trading, he had a far better understanding of the life of the townsmen than thinkers who had spent most of their lives in predominantly 'academic' environments. With the daily practices of merchants in mind, Ishida articulated the idea of work prevalent among the Kyōto merchants, and diffused it through lectures and the writing of family precepts of trading houses. At the same time, he fused the idea of 'learning of the mind', which originally derived from the Neo-Confucian ideology of the pursuit of 'true' mind, with the practicalities of trading; he laid down a system of cultivation that commoners could practise in everyday life. In short, he played a crucial role as a medium through which the tacit idea of work as embraced by merchants was conceived and fertilised with ideology, and was thus imbued with intellectual expression.

Tokugawa trading houses trained their men in reading, writing and calculating, and Ishida, like other apprentices, received such an education during the course of his service. He, however, did not confine his learning to the acquisition of such basic skills; although he did not receive any formal education in classical learning, he gradually but steadily accumulated 
knowledge of the Chinese classics, including such Confucian writings as the Analects, Mencius, and the Mean. Ishida did not have an affiliation with any particular school of the Tokugawa intelligentsia; nor did he pursue a prolonged scholarship under the direct instruction of any distinguished scholar of the time. He was a common man who was self-educated throughout. Although his teaching was later called by his pupil 'Sekimon Shingaku', or 'Ishida's school for the learning of the heart', he did not have sustained contact with scholarly representatives of any shingaku school in Japan. [2]

Ishida gave his first lecture in Kyōto in 1729, when he was forty-five. His lectures involved the so-called 'Four Chinese Classics' (Shisho); the Analects of Confucius, Mencius, the Great Learning, and the Mean. Lao tzu and Chuang tzu were also used in his lectures. These difficult texts were rarely accessible to the common people of that time, but through referring to everyday occurrences in his discussion of sublime texts, and giving question and answer sessions in lectures, Ishida made the content of the texts relatively understandable, and in fact drew a large popular attendance. No tuition was required to attend lectures by Shingaku scholars. No references of any kind were necessary either. Those factors all contributed to the popularity of Shingaku.

Ishida's leadership ended at his death in 1744 , fifteen years 
after he first began lecturing. His disciples however continued to spread the teaching of their founder. Its popularity grew steadily in the first fifty years, and grew with more rapidity in the Tenmei period (1781-88). At its zenith, Ishida's teaching prevailed among more than thirty-six thousand pupils in over sixty domains. In later years, however, the Shingaku movement tended to be downgraded into a common morality movement, particularly after the proclamation of the Kansei Prohibition of Heterodox Learning in 1790 . 


\section{Chapter 3: Ishida's thought on work and the economy}

\section{Ideological background}

Ishida was not a thinker who produced numerous ideological works. Tohi-Mondo and Seikaron ('Discourse on the Wise Government of the Household') are virtually the only accounts written by Ishida himself with the assistance of his pupils. Another source of Ishida's thought is the twenty-four-volume Ishida Sensei Goroku or 'Memoirs of our teacher, Ishida', a retrospective collection of Ishida's lectures and questionand-answer sessions made by his pupils. Tohi-Mondō is perhaps Ishida's chief ideological discourse, for it includes not only moral and behavioural teachings for everyday life, but a metaphysical assessment of the origins of the universe, man, and all other beings.

Research by Shibata Minoru has shown that Tohi-Mondō draws on a total of seventy-eight different sources, with references being mostly to the Analects of Confucius (referred to 133 times and quoted 75 times) and to Mencius (referred to 116 times and quoted 54 times). The Great Learning and the Mean are referred to twenty times each; other sources of Confucian, Buddhist, and Shintō thought appear much less frequently (twenty-one accounts are used only once each). [1] Thirty-one volumes of Buddhist 
accounts are either used or referred to (as against thirty-eight Confucian accounts), however only once in most cases.

What, then, is the ideological content of Tohi-Mondō? Ishida argues in Tohi-Mondo that the ultimate aim of both Buddhism and Confucianism is the same - to attain unity with one's nature (ten or sei). But diversity looms, he argues, when it comes to the means of attainment. Buddhism, in Ishida's view, requires the adherent to follow a specific path to attainment in an environment dissociated from secularity [2], while Confucianism recognises one's pursuit of moral practices in the secular context as the path to fulfilment:

'Confucianism equates the practice of the ways of Gojō and Gorin [3] in a secular context with the 'Way of Heaven' [as the ways to attain unity with one's nature], while Buddhism does not have such ways' [4] '... Buddhism and Confucianism share their ideas concerning the concept of man's nature [ri or sei], while they differ greatly from each other in terms of the means of attaining it.' [5]

As shall be shown later in this chapter, Ishida argues that the means of cultivation lies in secular activities, particularly in one's everyday work. He dissociates himself from Buddhist thought in this respect. Ishida's view of Buddhism may need some qualification, however. Japanese Zen popularisers, Suzuki Shōsan (1579-1655), for instance, regarded secular pursuits in everyday life as the means to attainment. [6] On the other hand, Confucian 
scholars of Sung China (960-1279) and thereafter developed articulated methods of cultivation marked by scholasticism and sublimity. From then on, the Neo-Confucian concept of cultivation emphasised the practice of formalised methods of self-refinement alien to the everyday life of the people. The only exception was a sect of the Wang Yang-ming school of Neo-Confucianism, which did identify moral action in a secular context with the means of cultivation. [7] It seems that Ishida was not profoundly concerned with these differences in ideas that existed between the sects and schools within Buddhism or Confucianism. He expressed his concept of cultivation in Confucian language, but he did not propound the elements of the scholastic method of cultivation advocated in Neo-Confucianism.

Ishida Sensei Jiseki or 'The Vestige of Our Teacher, Ishida' suggests his association with Shintoism at an early stage in his life; it shows that he intended to become a private Shintō preacher when he went to serve at a second merchant house in Kyōto at the age of twenty-three, and was consistently pursuing an orthodox 'morning Shintō practice'. [8] His references to Shintō texts, however, appear much less frequently in both Tohi-Mondō and Seikaron, compared with the intensity of reference to Confucian sources. The influence of Shinto upon Ishida's later thought may ultimately have been marginal, despite his early acquaintance with 
the religion.

Studies conducted up to the present time show that Ishida's thought reflected the ideas of all the major East Asian teachings Confucian, Buddhist, and Shintō. No scholar has so far been successful in determining which of these formed the chief ingredient of Ishida's thought. [9] However, it could be argued that his thought has a stronger association with the Confucian mode of thought, particularly with that of Mencius, than with the other two; Mencius was extensively referred to by Ishida, particularly when composing his core argument. On the other hand, his idea of the cosmos reflects the metaphysics of Chou Tun-yi (1017-73) and Chu Hsi (1130-1200), two of the preeminent Neo-Confucians in Sung China who composed a concrete and structural mode of metaphysics encompassing both the universe and man. Uekawa Kisui (1748-1817), a Shingaku disciple, stated that Ishida's thought followed on directly from the ideas of Chu Hsi, while Kamada Ryuo (1754-1821) argued that it had a direct affiliation with the thought of Chu and Chou. [10] In fact, Chou's Diagram of the Supreme Ultimate (Taikyoku Zusetsu) was frequently referred to by Ishida in his discussions of the cosmos in Tohi-Mondo, as were the works of Chu Hsi. [11]

The ultimate aim of a Neo-Confucian was to become a sage, the state in which one attained moral purity and was unified with 
the cosmos. Neo-Confucians stressed moral cultivation and signified intellectual investigation as essential activities in preserving self from evil impulses and human desires and maintaining unity with one's own nature (sei). [12] Cultivation was also sought in order to unify oneself with the pattern of change in the cosmos, thereby affecting the transformation of things in society and the cosmos. [13] Specific methods advocated by Neo-Confucians to achieve these ends were the investigation of things and the extension of knowledge (kakubutsu-chichi), adherence to seriousness (kyokei), and exploring or 'fathoming' principle (kyüri). [14] For Ishida, being at one with one's own nature was also of prime importance, as was the necessity of refining and spiritually disciplining self. However, although for the Neo-Confucians the orthodox means to this end were study and meditation, for Ishida the answer lay in the everyday world, namely, in one's intensive devotion to work.

Ishida's thought: Work as the process of self-cultivation

'One shall be aware that one's standing is the actualised state of Heaven's will [tenmei]. This is duly what Confucius teaches us also. If one were aware of this, how could one be negligent of one's shokubun?' [15] [In other words,] 'one's being is the nature [ten-sei] itself . . samurai are samurai, peasants are peasants, and merchants are merchants ... if one is loyal to Heaven's assignment, and is devoted to it, one shall certainly reach the state of fulfilment. [16] 
Ishida argues here that each man born in this world is the actualisation of Heaven's will; those belonging to each occupational group have assigned tasks to pursue. His ideas thus look almost identical to the Neo-Confucian conception of man and his duty. However, what distinguishes Ishida from the Neo-Confucians is that he recognised immersion in assigned tasks as the means to fulfilment. And, through it, he advocated that people could become active entities in the process of self-cultivation, as this excerpt from Tohi-Mondō shows:

'While the assignment might differ from one person to another, one's nature is the same [ri wa ichi nari] . . all people, from the Sage to commoners, are entitled to cultivate themselves; how can the people of each status group - samurai, peasants, artisans, and merchants be different from one another in cultivating self?' [17]

Ishida draws on the classic Confucian tradition to argue for self-cultivation as the universal right, which is not the case in the later Neo-Confucianism. This thesis of Ishida is noteworthy, for it has at least two important implications. First, it suggests that cultivation could be sought not only by a particular sector of the population (the ruling class) through sublime means but equally by people in all status groups. As has been pointed out by Watanabe Hiroshi, Neo-Confucianism aimed to cultivate the ruling class or 'upper strata' of the population. The elite was entitled to 
self-cultivation, and thereby to influence and transform society and the cosmos. On the other hand, Neo-Confucianism does not designate any means of cultivation for the masses. [18] Indeed, such accepted methods of cultivation in Neo-Confucianism as kakubutsu, chichi, and kyūri required a lengthy and intensive commitment to particular formalities, which could in practice be pursued only by a certain elite population. The masses were the indirect recipients of this influence, passive entities to be transformed by the force of the cultivated elites. H.D. Harootunian states that 'in Neo-Confucianism, the fundamental division was between the sage who possessed a certain kind of knowledge and the people who did not, between ruler and ruled. Knowledge entitled some to rule; it also required the acquiescence of those who had not attained knowledge.' [19] In this statement, Harootunian simply intends to suggest the role and significance of moral knowledge in regulating society in the Neo-Confucian mode of thought; he does not intend to clarify which entities were subjected to cultivation and which were not. One could point out, however, that an important division is assumed here between ruler and ruled; between those who were entitled to cultivate themselves and those who remained mere passive recipients of influence from the cultivated population. Although the issue may still be debated, conventional Neo-Confucian methods of cultivation were designed 
exclusively for the upper strata of the population.

Ishida identified the work of each status group with cultivating action, thereby breaking away from the conventional assumption regarding cultivation in the Neo-Confucian mode of thought. Thus Neo-Confucianism, with its emphasis on the scholarly and the contemplative, was pushed to the background and everyday work was promoted as a means to fulfilment. Refinement of self was at last no longer solely within the reach of the learned.

The second implication is that it was not only the practice of 'moral constants' in the secular context that Ishida emphasised as the means of cultivation. That he strongly argued that selfcultivation could be attained through devotion to one's 'work' is clear from the following:

'A man asked Ishida: Is it the practice of Thirty-three hundred acts of rei [courtesy] and gi [righteousness]' which you are referring to as 'practical action'? If it is so, peasants like us are not entitled to pursue that action; unlike the academicians, we cannot [afford to] practise such an action.

Ishida replied: The 'action' I am talking about is not thus. The learning of rei and gi which you mentioned might enhance the learning of dignity, but it might foster, as Confucius says, 'partial learning'. I shall explain the 'practical action' which I meant to advocate: If you are a peasant, you shall work from dawn to dusk. You shall devote yourself [to agricultural work] extensively; cultivate in spring, weed in summer, harvest and stock in the autumn. You shall always think of the way to produce more, even down to a single grain of rice ... What I shall stress 
here is that if one is aware of one's own nature [kokoro], and work extensively, one shall be blessed with a great feeling of pleasure despite physical exhaustion.' [20]

Here Ishida identifies the pursuit of agricultural tasks with cultivative action. The means of cultivation is not confined only to such 'moral practices' as the pursuit of the five moral constants and five social relationships; an intensive devotion to one's occupation preserves heart and cultivates self.

Researchers on East Asian religions have pointed out that Shingaku teaching emphasises the profound reflective contemplation and other contemplative means, which were the commonly advocated methods of self-cultivation in the orthodox Ch'eng-Chu teaching in China. R.N. Bellah argues that Shingaku teaching stressed the pursuit of 'quiet-sitting' so as to "exhaust the heart" (kufū or seiza) [21], while William T. de Bary, following Bellah, propounds that Shingaku's concept of self-cultivation followed on from Ch'eng-Chu teaching and practice, which emphasised more on the exercise of spiritual and moral discipline in order to 'fathom' self than on 'investigation'. [22]

It is true that the pursuit of such sublime practices - alien to the life of ordinary people - were increasingly emphasised in the later Shingaku movement in the post-Ishida era, particularly in the early nineteenth century. However, the vital element of Shingaku 
teaching in Ishida's time lay, as we have seen, in its emphasis on devotion to work. He stressed no sublime practice, such as quietistic detachment ('quiet sitting') or scholarship, as the primary means of practice, although he did recommend $k u f \bar{u}$ as a secondary practice to be carried out in one's 'spare time'. [23] The following observation by Ishikawa Ken supports this view:

'Few thinkers were more enthusiastic than Baigan in discoursing the way of household work $[k a s h o k u / k a g y \bar{o}]$... He revealed the origin of kashoku, the importance of it, and explained it in detail with numerous examples. He was not an example of the ordinary [Japanese] Neo-Confucians who tend to advocate only ethical discourse of a general kind; he explained moral actions along with the idea of kashoku.' [24]

Indeed, Ishida himself experienced his first enlightenment (satori) when he was totally absorbed in caring for his sick mother, while the conscious efforts he had made for reflection before that did not get him anywhere. [25] In other words, he was enlightened through an intensive involvement in secular action, not through "quiet" reflective effort or study of any kind.

Neo-Confucian advocacies of the investigation of things and the extention of knowledge may both be considered as 'active' elements of the means of cultivation, while adhering to seriousness and the 'fathoming' of principle may be categorised as 'quietistic' elements of the means. 'Active' as well as 'quietistic' means may 
both be needed in an ultimate sense to cultivate self. In Ishida's

thought, it was the 'active' means - one's devotion to assigned

work - that was emphasised, while quiet-sitting was recognised as a secondary means to attain self-cultivation.

Ishida's theories on cultivation invariably had major implications for his views of the Tokugawa social structure. As the following passage from Tohi-Mondo suggests, people - the 'cultivated entities' - are all active entities in forming a part of the social process and its betterment:

'Samurai are retainers as they stand; not only samurai, peasants are also the retainers of the nation on the rice field; merchants and artisans are the retainers in the town; ... merchants serve society with trade ... society cannot stand without the contribution of all people in the form of the pursuit of their own assignments. [26]

The people in each status group were the retainers of the nation, and the assignment of each was a task which invariably involved the enhancement of social well-being. In Ishida's thought, commoners were to fulfil the assigned tasks for social good as the great figures of the past did:

'Yao devoted himself to fulfilling the way rulers are supposed to; Shun devoted himself to fulfilling the way pious men are supposed to; Duke of Chou devoted himself to fulfilling the way bureaucrats are supposed to; and Confucius devoted himself to fulfilling the way scholars are supposed to. They are, in Mencius's words, following the intention of their nature [sei] ...' [27] 
It thus became possible, at least in theory, for the masses to cultivate themselves so as to attain unity with nature, and actively participate in social betterment, which had until then been possible for the small number who could afford to go through particular processes of investigation and meditation. Furthermore, economic activities such as production, distribution and exchange had ideologically come to be recognised as a cultivating activity.

A school of thought that emphasised learning, selfdevelopment or self-cultivation through secular means had already developed in seventeenth century Japan. According to Kojima Yasunori, an intellectual historian of Tokugawa Japan, thinkers in the 'Classical School' (Kogakuha), Yamaga Sokō and Itō Jinsai in particular, advocated a practical and 'action-oriented' method of training in attaining cultivation, while casting doubt over what they perceived as the 'static' method of training such as contemplation, adherence to seriousness, and fathoming principle, the accepted methods of cultivation in Neo-Confucianism. [28] Yamaga refrained from any reflective or contemplative means of cultivation, which he believed to be as elusive a means as trying to make a mark on water (mizu ni shirushi wo nasu ni hitoshi), and advocated instead the deployment of a more tangible, specific 
method of training as a way of refining one's being from the exterior, that being the practice of decorum and civility in everyday occasions. [29] Itō Jinsai argued, in the words of Najita, that 'metaphysical absolutes could not be known by the limited human mind, so the "observation" of nature should not be thought of as a reliable epistemology that would lead the human mind to such grandiose discoveries . . "Observation" cannot serve as an approach to reach conclusions as to transcendent and timeless norms of goodness that Neo-Confucian cosmologists have claimed.' [30] Both Itō and Yamaga expressed a strong inclination toward practical, tangible means of learning to be practised in a secular context, although the 'secular action' they refer to has more to do with 'moral' action than to one's assigned work.

The practical learning (jitsugaku) school, as it is generally termed, emerged not only among the Tokugawa intelligentsia but in the intellectual schools of other East Asian states. In fact, it developed in China much earlier than it did in Japan. According to Yu Ying-shi, a sect of Wang Yang-Ming's school of Neo-Confucianism which emerged in the sixteenth century, identified the secular deeds of peasants, artisans and merchants as the 'way' of cultivation, and emphasised learning through daily pursuits. [31] The emergence of the schools of keisei chiyo and riy $\bar{o} \vec{o} s e i$, two of the preeminent practical learning schools in 
Korea, was a major intellectual sprout in the nation, particularly after the seventeenth century. [32] But Yu's study does not sufficiently describe the overall impact of the thought of Wang's school upon the common people of China. Some studies even claim the contrary point of view; Minamoto Ryōen, for instance, argues that the growth of practical learning schools stagnated in the late Ming (1368-1644) and early Ch'ing (1616-1912) China, and did not prevail over the orthodox Neo-Confucianism which was in favour of meditation and scholarship. [33] According to Pak, practical learning schools emerged in the second half of the seventeenth century in Korea and flourished in the early nineteenth century. [34] But one can hardly claim that this thought system infiltrated beyond the realm of the intelligentsia and into the masses as a popular, practical means of cultivation in everyday life. [35] Japanese jitsugaku, in contrast, not only exhibited a major intellectual élan from the early stage of the Edo period but also spread through to samurai, merchants, and peasant leaders both as thought and as a practical means of self-development. [36]

De Bary argues that the peculiarity of jitsugaku lies in the 'shift in the center of gravity from an early emphasis on moral substantiality and metaphysical truth to the pursuit of objective, empirical investigations serving utilitarian ends'. [37] It served to construct the 'preconditions' for the development of 
proto-scientific empirical rationalism as well as a radical moral activism. [38] The thought of Ishida differs itself from the jitsugaku of de Bary's description in that it does emphasise the quest for 'metaphysical truth' and the refinement of self, and it is not designed so much to serve utilitarian ends. One might argue, however, that the predominance of jitsugaku as a substantial intellectual trend in Tokugawa Japan certainly encouraged Ishida to improvise a powerful and widely acceptable method of cultivation. As a thought system which advocated 'work' as the means of cultivation, Ishida's method gained considerable support among the common people in the mid-Edo period.

Ishida's thought: The justification of trading

The second half of the seventeenth century saw a rapid expansion of transport systems on both the land and sea throughout the whole of Japan, thanks to the massive extension of road systems and other communication infrastructures. Great trading houses such as Mitsui, Kōnoike, and Sumitomo extended their businesses not only in the Kinai region but in Edo and its environs, diversified their businesses, and founded large shops in the cities. The era was marked by trade expansionism, however, increase in trading house bankruptcy followed shortly; trade growth had begun to slow down by the beginning of the Genroku era 
(1688-1703), due largely to the saturation of the domestic market and the unavailability of foreign trade occasioned by the seclusion policy. Some succeeded in stabilising and laying down solid business foundations after the era of rapid expansion, while a substantial number of trading houses, particularly those run by second or third generation shop owners and managers, faced difficulties; in fact, memoirs and diaries of the Genroku and Kyōho (1716-1736) eras show that numerous shops closed down; traders in these eras were demoralised through the loss of the unlimited business opportunities for expansion which their predecessors had fully enjoyed. Many became indulgent $(h \bar{o} t \bar{o})$ and lazy, and lost business incentive. [39]

Samurai also began to face economic difficulties in the Kyōho era, and from then on were often in a state of constant poverty. The prosperous state of some rich merchants provoked, notwithstanding the fact that numerous trading houses were closing down, no little antagonism, as this account by Ogyū Sorai shows:

'Merchants' accumulation of wealth was never so enormous as it has been for the last one hundred years ... All stipends are absorbed by the hands of merchants, and samurai have become poorer every day.' [40]

Ogyū attributed the impecunious state of the samurai to excessive exploitation by the merchants. Their "sleight of hand" in 
circulating goods whilst absorbing profit for their own ends and at the expense of others was condemned. [41] In fact, the Kyōho period of the mid-Edo could be seen as the time when antagonism towards the activities of merchants first became apparent. And it was exactly at this time that Ishida began his career as a Shingaku master. With the prevailing atmosphere as it was, what Ishida needed to do as a popular thinker was twofold: he needed to formulate a new meaning for trading not based on mercantile expansionism, in order to provide demoralised merchants with renewed incentives in an era of limited economic growth. On the other hand, he had to establish the legitimacy of trading and a raison d'etre for the merchants so as to eschew fierce criticism of them from others, particularly, the samurai. With these aims in mind, he argued the following:

'If all the merchants were involved in peasantry or artisanship, there would exist no function for the exchange or circulation of money or goods. That would, without any question, bring about a paralysis in society. Samurai, peasants, artisans, and merchants are all mutually interdependent entities in the machinery of society. If society did not have any one of them, there would be serious difficulties in the functioning of society.' [42]

Here Ishida spoke of the functional indispensability of all occupational groups in Tokugawa society, including merchants, without whose undertakings such as trade and distribution society 
would not be run. He also remarked:

'... samurai, peasants, artisans, and merchants all have their own ways. Not only the people in those classes, even a beggar has his own way.' [43] 'How can the way of the merchants differ from that of the people in other status groups? As Mencius said, there is only one way for the people of each status group; how could there be two ways?' [44]

Ogyū condemned merchants for unfair profit-making designed to benefit only their own group. In contrast, Ishida was supportive of mercantile activity, for it functioned as a medium through which shortcomings and oversupply in society were met. A merchant's devotion to his task was the righteous 'way' in the secular context which not only served to increase the merchants' profit but also benefited the people in other status groups. Ishida even went so far as to legitimise mercantile profit-making in the following way:

'Artisans' earning from their crafts is equivalent to the stipend. Peasants' making their living through agrarian work is also equivalent to the stipend.' [45] 'Accumulation of the profit from sales is the 'way' of merchants ... the profit from trading is also equivalent to the stipend.' [46] 'Without profit, it is impossible to sustain a merchant's household business.' [47]

He thus compared merchants' profits through trading to the samurai's stipend. He argued that both were the product of 
devoted action to one's occupation, and thus it was neither legitimate nor fair to castigate merchants for their profit-making. On the other hand, Ishida was aware of the existence of merchants who practised unfair trading for the sake of one-sided benefit. To clarify the 'righteous' way of trading, he pronounced the following cautious words:

The way of the merchant is based upon a mutually beneficial way of trading. A ruffian trader tries to cheat his customers, in order to make a profit on that one occasion only. A merchant of this sort should not be considered as equal [to righteous merchants].' [48]

Here Ishida denounces traders who are out for short-term profitability at the expense of their customers, and do not care about a long-term partnership with their clients leading to a prolonged beneficial mutuality. Such traders received no respect from the rest of the population; nor did they develop a solid basis of trading with which to continue their assigned task. Ishida did not support such traders.

On one occasion, he pointed out that the 'paddy which merchants have to cultivate exists in people's mind'. [49] Every act of trading or other assigned task should be conducted - as a peasant would cultivate his soil - with the greatest care. Here then is the bedrock of Ishida's perception of commerce and the social role to be played by merchants: trading was, in his view, not a 
matter of merely circulating goods, but also of cultivation. It was the prerogative of merchants to provide their customers with invaluable information and those goods and services best suited to them. Merchants, as specialists familiar with both the customer's needs and the products available, were entitled to act as mediators between the two sides, in order to enrich their customers with goods and services and to provide the producers with information regarding the customer's requirements. The activation and betterment of this interactive process was the merchants' mission: through it the customer's mind was enriched, as was that of the merchants with the practical knowledge of trading they acquired, and, ultimately, with insight into human society. Thus, 'careful cultivation' and 'mutual benefit' appear at the heart of righteous trading in Ishida's thought. He also said the following:

'Customers are the 'providers' of your income. If you take the best care of your customers with sincerity, most of the commodities you intend to sell will suit the customer's mind, and will be sold. If you make your best effort to provide customers with the best suited goods, you will have nothing to worry about in your career as a merchant.' [50]

Customers were to be treated with integrity by traders whose good intentions became objectivised in the form of suitable goods and services. In turn, traders received their income, profit or 'stipend', as a reward for the caring effort they made. Mutual 
beneficiality continues thus.

One might wonder how Ishida assessed profit in the case of an economic force majeure. He remarked:

'A commodity which is worth 100 me may be sold at 90 me at times due to market fluctuations. You will suffer a loss when the market fluctuates thus. Then there are times you could sell it at 120 to 130 me ... Such a rise and fall in price constitutes a force majeure caused by the 'manoeuvre' of Heaven; it has nothing to do with the merchants' will.' [51]

It is arguable that there was a degree of market manoeuvring at the hands of mercantile giants in the mid-Edo period. It would not be appropriate to conclude from the above statement that Ishida, after serving trading houses for three decades, was not aware of the existence of this. However, neither in Tohi-Mondo nor in Seikaron is the market itself discussed to a great extent; Ishida seems to have concentrated more on the justification of the merchants' place in society, their assigned tasks, and their necessary attitude in daily life.

By focusing on these subjects, however, Ishida successfully set out a thesis through which merchants could view themselves as not essentially inferior to other people in different status groups, and their deeds as legitimate compared to other tasks: trading was of mutual benefit to both producers and consumers. Profit making was justifiable as long as it was the result of one's fervent action 
aimed at the fulfilment of that objective. Ishida's thesis thus legitimised the then disregarded merchants and their economic activity.

On the other hand, Ishida argues that trading was an assigned role given to merchants, through which they should cultivate self. He formulated this system of cultivation with reference to both the Neo-Confucian concept of attainment and the work of merchants. The everyday work of the common people, even those in the lowest ranks of the Tokugawa social strata, was identified with the idea of self-cultivation in the thought of Ishida. As such, members of all status groups were empowered to become active participants in their own self-refinement. 


\section{Chapter 4: Skill, management, and workers' initiatives}

\section{in Ishida's thought}

In Ishida's view, the fulfilment of role assignment in the secular arena leads to the refinement of 'inner self'. It was not he alone, however, who related work to the inner cultivation of self. As we have already seen, Suzuki Shōsan in the late seventeenth century argued that agricultural work and trading were the process of shugyō itself, which enriched one's spirituality. However, Ishida's thought was considerably more specific and interrelated with actual business process in trading than Shōsan's; as a thinker with active experience of life in trading houses, he spoke of commerce, the skills necessary for the conduct of household business, and the importance of such 'economic' matters as management. This chapter examines selected elements of Ishida's discourse on work with reference to such economic concepts as 'skill', 'management', and 'work initiative'.

\section{The concept of 'skill' in Ishida's work thought}

The valuation of skill in the West

One of the essential elements consistently referred to by economic historians and sociologists in the discussion of work is 'skill'. In Paul Thompson's words, skill has been 'fundamental' to European cultures for centuries, and 'already had the double sense 
of mental reasoning and discrimination with practical ability in its medieval usage'. [1] Charles More defines skill as a combination of the ability to perform complex manual operations and the knowledge of materials and tools. [2] Braverman quotes in his Labor and Monopoly Capital the following description of 'skilled work':

'skill covers his ability to imagine how things would appear in final form if such and such tools and materials were used ... he can estimate accurately both aesthetic appeal and functional utility, organise his tools, his power and his materials in a way which accomplishes his task and gains him livelihood and recognition ...' [3]

Although the word 'skill' was not yet the preeminent linguistic representation of artisanal presence in the first half of the eighteenth century in Europe, and its solid conceptualisation did not occur until the early period of industrialisation, it had already been recognised by artisans of the age as an 'individual technical property', as a means of distinguishing themselves from 'ordinary' workers; it was 'deeply embedded in the culture and consciousness of the artisans, as was the assumption of the respect of others for it'. [4] Skilled workers retained, as Marx argued, considerable power to safeguard their interests in the 'period of manufacture', because, in those days, handicraft skills remained the technical basis of manufacture. [5] As industrialisation 
progressed, the combination of capital-intensive factory operations and cheap labour began to erode their 'property' [6]; the trend brought with it the gradual replacement of handicraft skill by another kind, and eventually culminated in the social phenomenon called 'degradation' and the 'deskilling' of work.

Deskilling is defined as the 'incorporation of the crafts, knowledgeable practices and elements of job control held by workers into the functions of management, or operation of machinery'. [7] In other words, it is the subordination of those skills and knowledge, which had long been possessed (supposedly) by the workers in pre-industrial times, to the capitalists. This has been regarded as a major ingredient in the alienation of work, and thus also in the deterioration of the sense of satisfaction in the practice of work.

H.A. Turner stated in his account of nineteenth-century English cotton spinning workers that those who belonged to a social group which was recognised as a 'skill group' did not need to be skilled in reality, as long as they belonged to the group; the sharp demarcation between skilled and unskilled, due largely to traditional apprenticeship, gave individual workers in the 'skilled' group recognition. [8] Turner's argument, however, needs to be viewed with some qualification; for a skill group is an 'economic' institution and the maintenance of a 'genuine' skill level among 
individual members is essential for its very existence (and for the construction of that skill). Nevertheless, it is important to recognise that skill is not an automatic consequence of any given technological advance. As has been emphasised by recent sociological studies of work, it is a social construct which is a product of various value-adding elements. These studies distinguish between 'genuine' (or technical) skill which arises from a technology, and the 'socially constructed' skill which results from the artificial distinction of a particular skill through the control of entry to the social group which possesses that particular skill, for example, by apprenticeship. [9] They stressed that it was this 'artificial' construction, rather than a worker's actual technical competence, that added (or generated) scarce value to a skill.

E.P. Thompson argued that 'when the people search for legitimations for protest (in industrial disputes), they often turn back to the paternalist regulations of a more authoritarian society, . . artisans appeal back to certain parts (e.g. apprenticeship regulation) of the Tudor labour code'. [10] That 'paternalist' regulation included apprenticeship regulation, through which a particular skill group could set up a demarcation line between skilled and unskilled, and thus make themselves 'exclusive' from the rest. They could preserve their skill and its social importance by that means, and this was presumably one of the primary reasons 
why protestors harked back to their past customs and regulations.

While this is not the place to examine the continuing debate on the term 'skill' in European history, it could be argued that skill represents the 'technological superiority' of individuals, and has been decisive in the economic and social career of the workers. For this reason, skill itself has continuously embraced recognition and social value.

In contrast, 'technology' of the 'individual' has not been manifestly posed as an important element of work in Japan, even in the modern period. The period after 1890 saw a rapid mechanisation of industries related to textile production. However, studies on industrial disputes show that neither workers nor industrial agitators vocally demanded the reinstatement of skill among individual workers during the disputes that occurred at that time. [11] The number of disputes increased sharply in the $1920 \mathrm{~s}$ following the end of the economic boom thanks to the Great War of 1914-1918. But the restoration of a 'household-like' system (kazokuteki keiei), which embraced the 'benevolent' employment relationship, was the dominant linguistic feature of the industrial disputes. [12]

In the Edo period, skill was linguistically represented in such terms as waza, giryo, and takumi [13], and was the mark of artisanal presence. Skill and technological superiority was 
regarded as an important asset in agrarian as well as artisanal society. The advancement of agricultural technology was marked by the emergence of such agrarian technologists as Ōkura Nagatsune. Ōkura, along with other technologists, produced numerous agricultural handbooks (nōsho). [14] These contained detailed explanations of advanced technologies. Peasants were keen to obtain these handbooks, and apply them in practice. However, most aimed to improve the economic welfare of the household, not to enhance an individual's potential to improve his economic status nor to raise the technological superiority of that individual over others.

Acumen in trading (shossai) and precision in calculation $\left(\operatorname{san}^{\prime} y \vec{o}\right)$ were seen as important assets in the Tokugawa mercantile environment. [15] But the recognition of those skills was not affiliated with individual recognition so much as with the succession of the business entity, the merchant's household (shoka). Ishida Baigan's thought on work recognised the importance of skill acquisition, but it was important as an 'instrumental' element to attain an end, which was the maintenance of the well-being of the household.

True, the occupational group which is most concerned with individual skill levels is the artisans. In the Edo period, artisans comprised only about five per cent of the population throughout 
the era. The percentage would be even smaller if one were solely concerned with those most skilled artisans who possessed a saleable skill. [16] One might argue that the absence of social valuation of skill in Tokugawa Japan was a logical outcome of this. But this is a common demographic feature of pre-industrial societies. A large proportion of the British population, for instance, remained agrarian even in the industrial period; a study shows that the bulk of the British population lived in an agrarian environment until the 1830 s, and that the largest single occupational group of the male population still worked on the land. [17] As far as the 'form' of employment is concerned, only five to six per cent of the working class were self-employed even in London, by far the largest centre of artisanal production, by the end of the eighteenth century. [18] The employment relations of most artisans retained a patriarchal tinge in the eighteenth century, although the relationship increasingly became freer throughout the period. [19] Skill was, however, taking on an intrinsic social value in British society. The praxis of the skilled artisan was one of the axes of industrial bargaining, despite the scarcity of a truly skilled population and its diversity. What then was the factor which made the individual technological property of 'skill' an important but less socially valued element of work in Edo Japan? What was the alternative notion of skill in Japanese social history? 
The work environment of the Japanese trading houses and skill

As we saw in Chapter 2, work in Tokugawa society was viewed as role-play, in which the tasks involved were plural. The succession of the household, the perpetual entity of lineal continuation, was the medium within which members identified themselves and maintained work motivation in agrarian households. Work in agrarian settings depended on skill of a less specialised but nonetheless plural kind, and was labour intensive both in agrarian and proto-industrial settings. The ability to work in consonance, to coordinate and allocate the existing labour force, were even more important than individual skill speciality.

The stable succession of the household business, and of the household itself in an ultimate sense, were of the highest priority in the trading houses of Kyōto in the second half of the eighteenth century, especially in large houses. Workers were recruited at an early age, and internalised job rotation was practised in order to enrich the workers with various types of job experience. A long-term employment system was already becoming an integral element of large trading firms. The labour market was internalised in these firms, and competition was enhanced within a certain demarcation (the household). [20] In short, workers were trained in-house from an early stage in their lives, and were 
expected to give a household a lifetime's service. They were trained to be 'skilful' in trading in the course of their service, but were expected to be adaptable to any tasks allocated to them. The skill of each worker needed to be of a plural nature in this job rotation system.

In such a work environment, single skill speciality was not a value in itself; value was attached to the secure continuation of the household, and the various skills which contributed directly to that continuation were considered of some importance. As the chart on the following page suggests, skill can be differentiated into three distinct kinds: first, there is 'genuine' skill which involves one's knowledge of materials and tools, and basic methods of carrying out complex material operations. Second, in addition to 'knowledge' and 'method', there is practical ability which embraces one's 'know-how' in utilising one's genuine skill in actual business, usually learned through on-the-job training. [21] Third, there is a skill of an even more general kind, namely, one's adaptability to varied tasks, one's capacity to facilitate consolidated task implementation such as communication between workers, and one's ability to organise an efficient workgroup and maintain good relations between workers and superiors. While these three aspects are inter-related in the actual implementation of tasks, they nonetheless constitute distinct kinds of skill. It was the 'genuine', 
individual skill, and the ability to practise it, which was generally recognised as 'skill'. The above discussion on skill in the West suggests that it was this type that was recognised as 'technological property' and imbued with social value. In contrast, it seems that skill of a general kind was considered of prime importance in Japanese trading houses in the mid-Edo period. Except in employment relations where highly specialised skills were prerequisite, i.e., in artisanal society, no skill of a technical kind embraced a predominant social value in itself in the Tokugawa work scene.

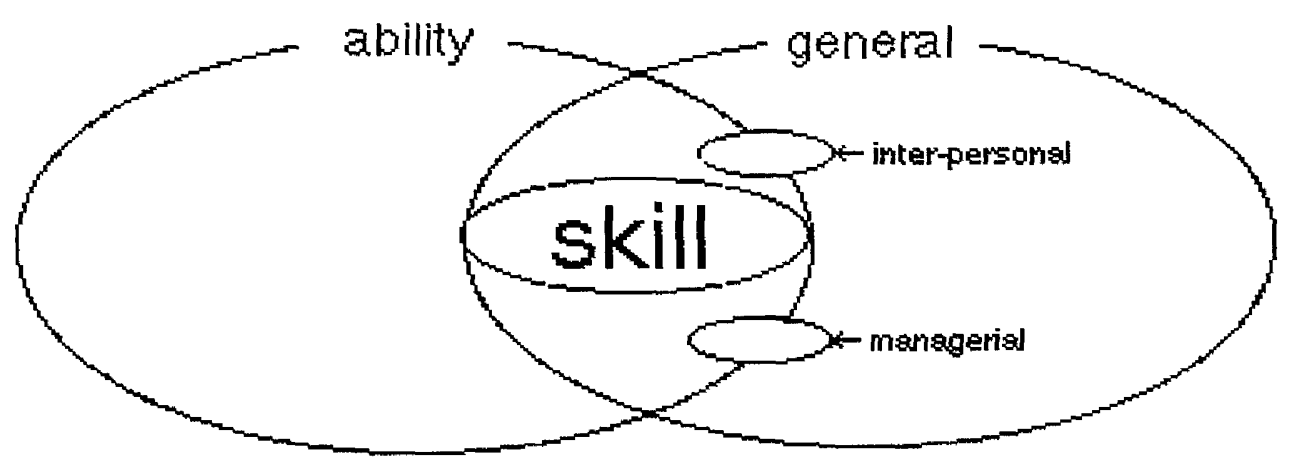

Ishida's thought: The justification of skill acquisition

Ishida served two trading houses in Kyōto. Based on his own work experiences in trading houses, Ishida stressed the importance of skill of the third type - 'general' skill - involving one's coordinative capacity to organise the workgroup, communication skill in sharing business information and work experience, and the 
ability to maintain good relationships with one's co-workers.

These skills may be termed 'managerial' and 'inter-personal' skills, calculated to enhance the efficiency of household business, and to avoid the disruption of the stable continuation of the household:

The master of a household shall be keen to form a consensus in every business decision that the household makes. Business matters shall be consulted first among the chief clerks [banto]. If no agreement is reached, then all the retainers [tedai] in the household must be summoned to discuss the matter. If retainers are hesitant to express their say, then employ a ballot [nyūsatsu] to settle the matter.' [22]

The above is an extract from Ishida's "Memorandum for the Well-Being of the Household", which was collected in his 'Memoirs', and was copied by his pupils when they formed their own family precepts (kakun). Here, Ishida refers to the importance of communication between workers and superiors. Communication, as he understood it, was not solely the expression of a superior's 'benevolent care' towards his retainers but a two-way information-exchange through which all - regardless of their position - were fully involved in the process of commercial decision-making. The memorandum even suggested a way in which the views of 'silent retainers' could be expressed - through a ballot system. Ishida also stated the following regarding the clerks (tedai) of the trading houses: 
'Tedai retainers of a household shall always be concerned with each other; they shall be keen to consult with each other, and even a tiny matter shall be discussed among them so that a consensus is reached.' [23]

An influential factor here is Neo-Confucian ideology which valued concern for others, the practice of mercy, loyalty, and so on. [24] However, these were taught not as 'moral' or 'ethical' practices but as necessary abilities in the running of a household business. Retainers were not merely to be ethically concerned with each other but were entitled to consult each other regarding business affairs, and to get involved in the mercantile decision-making process. In short, Ishida emphasised the practice of managerial and inter-personal skills, geared to activate information transmission among co-workers and improved the workers' sense of participation.

The following words collected in Ishida's Tohi-Mondō also illustrate the importance of the skills discussed above. Responding to a question concerning personnel affairs and promotion within a household business, he argued that

$\therefore$. . if there be no difference in kiry $\bar{o}$ [between the two retainers], the retainer who started his service to the house earlier shall be promoted sooner; . . . if there be a difference in kiry $\bar{o}$ between them, the superior shall be promoted to the higher position sooner; . . . the difference is caused by "Heaven's intention"; not attributable to individuals.' [25]

Here Ishida spoke of the meritocratic settlement of personnel 
affairs. Worthy of note here is his use of the term 'kiryo' (器量); it suggests his strong concern with abilities regarding inter-personal matters. Indeed, if he were concerned only with an individual's competence in trading, perhaps Ishida would have employed such terms as waza or giryo , the terms in existence in the Edo period that best correspond to the English word 'skill', and/or shōsai (acumen in trading) or $\operatorname{san}^{\prime} y \vec{o}$ (precision in calculation). Instead, he used the term ' $k i r y \bar{o}$ '. The word consists of two distinct

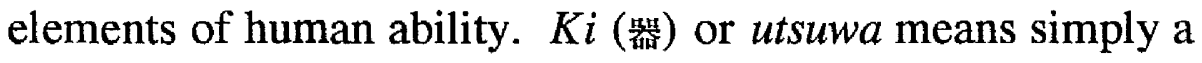
'receptacle', but it also means one's 'capacity'. $K i$ in the context of 'kiry $\bar{o}^{\prime}$ means the knowledge and power to carry out a task. The word $r y \bar{o}$ (量) also has two distinct meanings; it literally means 'quantity', but its secondary meaning is one's ability to 'read' another person's mind. The term ryō in the context of kiry $\bar{o}$ also means a place or a man fulfilled with virtue (toku no mitsuru tokoro). [26] The word kiryō therefore means not only individual technical competence in a speciality, but the ability and willingness to be concerned with others, through which good inter-personal relationships can be maintained. Ishida's use of the term kiryo, not giryo or waza, thus expresses the importance he places on managerial and inter-personal skills. 


\section{Retainers' initiatives and subjectivity in work}

The secure succession of the household was prioritised in trading houses, but the stability of the household was not sought through the enforced submissiveness of the household members; as we have seen, retainers were encouraged to have their say. Ishida spoke of retainers as subjective entities who were self-contained in thought, initiative, and judgment. He commented in this way in his 'Memoirs':

'. . A man should rise to his feet [ware wo tateyo!] when he conducts his household work [kagyō]; think of kagyo as if it were an inseparable part of the body [teashi no gotoku hanarezaru] . . Be firm of will, hold onto your principles; one should be concerned to act upon the will; one's willingness and effort to be self-reliant constitute an expression of loyalty.' [27]

Modern Japanese scholars have long focused on Ishida's emphasis on retainers' devotion to a lord, and failed to account for his discourse on the subjectivity, initiative, and spontaneity of retainers. [28] Ishida's thought tended to be regarded as yet another inducement for internal constraint, loyalty and submission, through which the status quo of the household unit, and, in an ultimate sense, of Tokugawa society itself was maintained. The degeneration of Shingaku into a common morality movement in later days has been attributed to this element of Ishida's thought. While Ishida spoke of the importance of a retainer's devotion to 
his lord on occasion, this must not be confused with a mere admonition of 'blind submission'; Ishida spoke openly of the right of retainers to express their own opinions, and emphasised on workers' subjectivity in work.

One might still wonder that, despite Ishida's advocacy of relative autonomy for retainers, they were never given sufficient decision-making power to topple their superiors; ultimate power rested in the hands of the superior $(k a c h \bar{o})$ in the trading houses of Tokugawa society, and thus there was, in reality, no room for retainers to manipulate business, or to be 'subjective' in their conducting of business matters. On this point, Ishida argued:

'Retainers [tedai] shall attempt to expostulate even their superior, if his deeds are judged unrighteous [29] . . . If the master be selfish, or indulge in dissipation, retainers should call for a discussion session so as to work out the means to stop the master's indulgence; if the master do not stop, retainers should jointly call for his retirement from the headship, because it will seriously damage the ancestors of the household.' [30]

Thus, for Ishida, the retainers of trading houses were not mere 'vassals' submitting blindly to the will of their superior, but had the power to influence managerial decisions, including those concerning personnel management at the highest level.

As discussed in Chapter 2, work was seen in Tokugawa society as a role to be played by the members of each status group. 
Ishida also viewed the work of each status group as the 'given' one. Contrary to, say, the Calvinist concept of work, which assumed the commoners' right to choose their own work [31], individuals were not offered the opportunity to choose an occupation. This being so, how could the opportunity exist for an individual to act 'subjectively' in carrying out his work? Here it is necessary to distinguish between freedom to choose the task to be pursued, and subjectivity in conducting the task itself. The freedom to choose work was almost unthinkable in Tokugawa society, where all tasks were recognised as 'sanctioned' role-play. A subjective attitude in the carrying out of one's task was however a matter of great concern, and, according to Ishida, a man could pursue his task with his own judgment, initiative, and spontaneity albeit within the limits of a given work circumstance. Moreover, job selection itself was, it appears, not a matter of great importance in the Tokugawa work context: for job valuation stemmed, as we saw earlier in this chapter, not from the type of job an individual dealt with but from his ability to sustain the household; the level of an individual's technical skill was important, but value was not attached to the level of skill itself. Furthermore, the mastery of managerial and inter-personal skills was valued regardless of job-type. In a work environment of this sort, one could argue that freedom in the choice of task loses its 
relative importance; the ability to practise general skills in any field of business was of greater importance.

The quality of work performance within a business enterprise depends on the ability and the degree of skill-specialisation possessed by the individual workers. Equally important factors which sustain that quality include organisational and human relational elements present in the work process. The organisation of the workgroup, its relations with superiors and management, the degree to which workers have control over decision-making, and the extent of communication between workers are all crucial in the efficient running of a business. Ishida was aware of this, and emphasised the importance of management and human resource coordination skills. He spoke of the potential of these skills to fully activate the abilities the household retainers possessed.

Ishida held that household work was in itself the process of self-cultivation. Individual competence in trading was an important asset, and immersion in trading was regarded as an act of enrichment. Hard work alone would not lead to self-refinement, however. For Ishida, 'process' meant not merely an intensive labour input but embraced the practice of managerial and inter-personal skills, and involvement in business 
decision-making in a household. It calls for the workers' 'subjective' participation, not merely a 'passive' adaptation or submission to one's superior in a collective entity.

The recognition of the importance of these skills, and the identification of them with work, are worthy of note, for they could be seen to represent a widening of the perception of work to include social relational and inter-personal elements.

Furthermore, the recognition of these abilities had begun to shape the actual meaning of work; a meaning that had arisen not merely from an individual's gain for the sake of personal profit, but from his role as an activator of human resources and as a contributory agent in the stable continuation and betterment of the household.

As was mentioned in the last chapter, there were thinkers and schools of thought which identified secular pursuits and the acquisition of practical knowledge with cultivation even before Ishida, not to mention the Zen popularisers of seventeenth century Japan. The T'ai-chou branch of the Wang Yang-ming school in late Ming China regarded the pursuit of morally responsible activity in the secular context, including work, as the process of cultivation. But, surely, the integration of such skills as coordination and management into the scope of work was found for the first time in the thought of Ishida. As such, it can be seen to mark a crucial development in the enlargement of merchants' 
perception of work in eighteenth century Tokugawa Japan.

\section{Religion, political values and socio-economic values in Ishida's thought}

R.N. Bellah attempted, in his Tokugawa Religion, to show the ways in which the rationalising tendencies in Japanese religion contributed to economic and political rationalisation in Japan. In a sense it represented the antithesis of Weber's view of the role and position of Japanese religion and its rationalising process, which assumed that religion neither played a vital role in forming people's values and behaviour, nor underwent a rationalisation process, which was crucial for the formation of an ethic of economic rationalism. [32] At the same time, Bellah conformed to the Weberian model, in that he saw religious rationalisation as contributing to economic rationalisation. Bellah argued that 'generalised' particularism serves as a functional equivalent for universalism. Japan's primacy of political values, of which collective goals and loyalty form a central concern, and thus normally prioritise ascription, reveals its strong association with performance values. [33] In a society where the polity takes precedence over the economy, 'work itself is not a value, but rather work as an expression of selfless devotion to the collective goal is valued', and this value system has brought about the same 
strong motivation for work. [34] In his discussion of Shingaku and the value system brought about by that 'religion', Bellah stated conclusively as follows:

'It was with a description of society as based on the lord-follower relation that we began and it is with that relation as fulfilling the sum of moral virtues that we end. Here then is the kernel of the received morality which the enlightened person who is free from selfish desires and united with the heart of heaven and earth will find perfectly natural and will perform without the least hesitation or doubt.' [35]

According to Bellah, Ishida counselled commoners to observe the lord-follower relations, and to be devoted and loyal to their superiors. It was this 'rationalised political value' which brought about the valuation of hard work in certain collectivities. Conversely, Bellah argued that the common people of Tokugawa Japan developed as mere subjects of submission to their superiors, and were entitled only to attain followership in a given collectivity. [36] However, it was not a 'blind submission' to a superior authority on which Ishida insisted. The retainers of a merchant household were to participate in business decisions, not merely to 'follow' the top-down orientations from the leader. They were even entitled to terminate the headship of the household. The head of the household was, in return, supposed to consult with his retainers before making any business decisions. Bellah argued in a concluding chapter that Japanese commoners 
are obedient, hard-working, and frugal, but possess no ability to initiate industrial and other changes [37]; 'improvements of standards or shifting of type of production was usually a result of compliance with orders from above, often directly from the government, rather than the sensitive response to a competitive market situation.' [38] T.C. Smith's account on the Japanese peasants in the late Edo period expresses the opposite view [39], and a recent study of a Japanese firm by Aoki Masahiko contradicts Bellah's speculative comment on present-day Japanese workers. [40]

According to Bellah, Shingaku regarded work as a curse and encouraged its followers to recompensate for their wrong doings:

'It is the religious aspect (of Shingaku) which appealed to all the deep inner needs of troubled people for salvation from their misery. This religious appeal reaches to the profoundest depths of human motivation. It is the linking of such motivation as this - of the weary for succor, of the troubled for repose, of the guilty for absolution - to the fulfilment of certain practical, ethical duties in the world ...' [41]

Bellah attempts here to identify the Weberian mechanism of achievement orientation; to reveal the sense of 'guilt' and 'tension' developed within man from which the motivation to work springs. Indeed, in Bellah's thesis, it was the practice of 'followership' and the sense of salvation advocated in Ishida's thought that shaped the work norms of the Japanese commoners. His thesis, however, 
neglects Ishida's discourse on the "followers' stake" in household business; neither the retainers' participation in business decision-making nor their ability to terminate the headship of a household was taken into account in his study, without which Ishida's thought can be seen as a mere admonition designed only to foster a retainer's submission. Bellah's thesis on the development of a work ethic through political and religious rationalisation certainly deserves credence since it highlighted economic development of a non-Western kind, a kind which till then had been considered merely 'feudal' or 'backward' (as it appears, i.e., in the Weberian thesis of 'Asiatic society'). Its overemphasis on vertical relations, however, needs serious qualification. 


\section{Chapter 5: The spread of Ishida's thought on work}

In the foregoing two chapters, Ishida's thought on work has been examined from several different perspectives. The impact of his thought was partially explored in Chapter 4 , but one cannot ascertain the overall effect of his thought on the mercantile environment of the Tokugawa era and, more generally, on the emergence of the perception of work in Tokugawa Japan, without a careful assessment of its actual diffusion. This chapter aims to deal with this issue.

The chronology and the process of the spread of Shingaku have already been covered in two major studies by Ishikawa Ken; Sekimon Shingakushi no Kenkȳ̄ and Shingaku Kyōka no Honshitsu Narabini Hattatsu. [1] In addition, Shibata's research closely examines the discourses of successive Shingaku leaders such as Teshima Toan, Uekawa Kisui, and Kamada Ryuō. [2] Miyamoto Mataji's classic work on the family precepts of the trading houses shows Shingaku's influence on the everyday life of merchants. [3] However, apart from Robertson's account on Teshima Toan and Anderson Sawada's recent work on the later

Shingaku movement [4], no research on the Shingaku movement after Ishida's death has yet appeared in the English language. Moreover, Robertson's work deals with the methods employed by 
Ishida's successor, Teshima Toan, to organise and transmit the ethical element of Ishida's teaching, but the economic element of Ishida's thought did not concern her. Anderson Sawada has dealt substantially with both the method of transmission and the concept of cultivation inherited by Ishida's pupil, but again the economic impact is left untouched. With all this in mind, this chapter will consider the impact of Ishida's thought on merchants of Tokugawa society in the running of trading houses in eighteenth century Japan.

We will start with a brief sketch of the nationwide spread of the Shingaku movement, based upon the research of Ishikawa and Shibata, to be followed by a discussion of the 'ingredients' of the teaching in the later Shingaku movement. The final section, we will trace the influence of Shingaku upon the family precepts (kakun) of trading houses.

\section{The nationwide spread of Shingaku}

Fifteen years of pre-eminence as leader and as chief lecturer of Shingaku came to an end when Ishida died in 1744 at the age of fifty-nine. The Shingaku movement, however, showed no consequent sign of decline but continued to grow under the leadership of his successors. Sugiura Shisai (1711-1760) succeeded to the lecturership at Ishida's old house in Kyōto, and 
also lectured in Ōsaka. The lecturership was succeeded to by his son, Muneyuki (1733-1809). [5] Teshima Toan (1718-86), perhaps the most recognised of Ishida's followers, not only lectured throughout Kyōto, Ōsaka, and the surrounding areas but initiated the establishment of Shingaku academic centres, generally called $b \overline{o s h} a$. The $b \overline{o s h} a$ system not only provided pupils with meeting places, but organised Shingaku into an entire 'movement'; it enhanced the regular and systematised delivery of lectures and the further extension of its membership. With the rise in popularity of Shingaku, such centres as Shüseisha (1773), Jishūsha (1779), and Meirinsha (1782) were founded in Kyōto. Five centres were also founded in Ōsaka in the first few years of the Tenmei period (1781-1788), along with those three Kyotō centres (both Ishida and Teshima delivered lectures in Ōsaka but academic centres were not built until this time). [6] While the usual number attending lectures in Ishida's time was forty to fifty, Teshima's lectures attracted from three to four hundred people up to a maximum of a thousand. [7] Teshima himself lectured in fourteen cities in seven different provinces where the centres were newly founded. Including the centres which were in the care of his pupils, Shingaku extended its influence to fourteen provinces. [8] Shingaku reached Edo when Nakazawa Dōni (1725-1803) built academic centres in Kanda and Nihonbashi in 1783. Thus, 
Shingaku centres were in place in the three major cities of Japan by the time of Teshima's death in 1786. [9]

Teshima Wa'an (1747-1791), Toan's son, and Uekawa Kisui (1748-1817), an adopted son who succeeded to the Uekawa family (chokkei of Toan's mother) inherited the leadership of the three centres in Kyōto, and administered the movement in the Kinai and its environs. [10] They also contributed to the spread of Shingaku to western Japan, and to Shikoku; three academic centres being founded in the domains of Awa and Tosa. [11] Meanwhile, Nakazawa continued to spread Shingaku not only within urban Edo but throughout the entire Kantō region. Ishikawa's research shows that the development of Shingaku centres was concentrated on the districts of Kinai in the years of Tenmei, while the Kanto region saw extensive development in the years of Kansei (1789-1800) and Kyōwa (1801-1803). [12] Shingaku spread also to the Hokuriku and Tōhoku regions in those years, owing largely to the efforts made by Nakazawa, and the number of Shingaku academic centres increased in the San'yō, San'in, and Shikoku regions in the years of Bunka (1804-1817) and Bunsei (1818-1829). Eventually, Shingaku reached all four corners of Japan, except Ezo (Hokkaido), the northern part of Tōhoku and Kyüshü, by the end of the Bunsei era. Shingaku reached Kyūshū in the following Tenpo years (1830-43), but the movement began to decline in 
Kantō at that time, due largely to the great famine. [13] Evidence shows that it was superseded by Ninomiya's more practical Hōtoku movement, and his shiho programme (cf. the villages of Kamado Shinden and Oda; see note 24 of this chapter).

In sum, twenty-two Shingaku academic centres were founded in the years between 1745 and 1786 (Toan's era), and fifty-nine were founded by his successors from 1787 to 1803 . Another fifty were founded in the subsequent Bunka and Bunsei eras. As a result, the number of $b \overline{o s h} a$ reached one hundred and thirty-one by the end of the Bunsei era (1818-1829). [14]

Shingaku is largely believed to have been a townsman's movement, spread only among the mercantile, urban population. However, its influence was not limited to this. Ishikawa's research shows that a total of 179 Shingaku centres were established, and of these, 58 were located in towns which were not castle towns (jōkamachi), and 62 of them were in rural areas. [15] This shows that although the spread of Shingaku was mainly within the urban population in Ishida's time, it gradually extended to the provinces and to rural areas.

\section{The teaching strategy in the later Shingaku movement}

Teshima and his followers made an effort to popularise Shingaku, notably by using accessible and simple vocabulary in 
lectures. Ishida taught sublime classics such as the Analects and Mencius in his lectures. Teshima also used these classic texts, but he declined to use difficult words and always couched his teaching in an easier vocabulary, often using words in five-seven-five syllibus (shichigochō) in both written and verbal teachings. A typical example of this is Jijo Nemuri Samashi ('For Boys and Girls: Waking Up from Sleep'), a collection of ethical discourses in easy shichigoch $\bar{o}$ words. [16] His teaching strategy of 'casual transmission', coupled with the establishment of Shingaku academic centres (bosh $\bar{a})$, could be seen to contribute significantly to the accumulation of a large following and to the spread of the movement. Ichimura's study of the teaching strategy of Nakazawa Dōni also reveals an emphasis on accessibility in the later Shingaku movement. [17]

Apart from the strategy employed to improve teaching methods, Teshima also adopted a strategy designed to target people by age group. For instance, Zenkun, which literally means 'provisional training', was the lecture programme designed to educate the young. Boys between the ages of seven and fifteen and girls between seven and twelve were encouraged to attend the programme, but it was also open to adult newcomers. Like the ordinary Shingaku lecture programmes, it did not require tuition of any sort. Lectures were held every ten days, usually in the 
afternoon. The contents of the teaching were not substantially different from that of the regular sessions, but the words and phrases used were made appropriate to the age of the students. [18]

A movement without a figurehead needs a clear ideological premise with which to determine direction. The Shingaku movement, which lost Ishida in 1744 , needed to establish a creed for this reason, and in answer to that need Teshima Toan wrote Kaiȳu Taishi or 'Creed of the friends of the Shingaku association' in 1773. It opened as follows:

'Kaiya Taishi Kogi Shishu [Main theme of the lectures]:

What our teacher Ishida taught us is to get to know the 'original mind' [honshin] of the Sages, and to be keen to preserve enlightenment brought about by these Sages. In order to know the original mind, one needs to be frugal, keen in self-refinement in everyday life, and diligent in cultivation.' [19]

To do this, Teshima advocated, through short articles in Kaiy $\ddot{u}$ Taishi, the practice of the five social relationships. [20] Following those ethical teachings, he spoke of immersion in one's household work (kagyo):

'Kagy of any kind - agricultural, artisanal, or mercantile - is not an occupation reflecting the intention of the individual; it is the task which is "wonderously" assigned by Heaven [fushigi ni shite uke'etaru kagyō nareba kore tenmei nari]. One shall thus not be negligent in the pursuit of kagyo; . . If one is not properly conducting kagyo, one will face great difficulties in life, disturb one's parents, and will 
end up betraying the virtuousness inherent in the original mind. [21]

As shown in Kaiy $\bar{u}$ Taishi, the practice of refinement through secular activities was the chief ingredient of Shingaku advocacy. The pursuit of the five social relationships and household work were recognised as the means whereby one becomes familiar with the 'essence of the Sages' and attains enlightenment. Teshima, following Mencius's words, argued that the 'way' lay not in the pursuit of the sublime practices of study and meditation but in everyday activities, particularly in the practice of diligence, frugality, and social relationships. Thus, the tenor of teaching in Teshima's era was not alienated from Ishida's teaching.

\section{Alienation from secularity in the later Shingaku movement}

Shingaku, however, gradually alienated itself from practical learning. It began to emphasise more 'extraordinary' activities such as study and meditation. [22] Under Nakazawa Dōni who took the initiative to spread Shingaku to the Kantō region, it was reduced to an ethical doctrine. Nakazawa emphasised the importance of following ethical teachings rather than the practice of cultivation through everyday work. Moreover, he ultimately emphasised the 'obedience' of the people. He frequently used the term 'shitagau bakkari' which means 'just obey', and was in part responsible for the eventual dwindling of Shingaku to a mere 
morality movement which encouraged passive adaptation to the social order. [23] True, Ishida did argue that the people should be fully suited to their given social environments and inherent assignments, but he also strongly advocated the subjective addressing of action toward an object of work. In contrast, submissiveness was the sole exhortation of Shingaku teaching under Nakazawa.

This propensity in the later Shingaku movement coincided with the great famines in the Kanto region in the first half of the nineteenth century. Shingaku was unable to cultivate people's attitude to counter the economic difficulties. For this reason, the movement's popularity declined sharply in the region in the late Edo period. Thus the way was paved for the more practical Hōtoku movement of Ninomiya Sontoku, and his shihō programme. [24]

\section{Shingaku thought in the family precepts of trading houses}

The era of great trade expansionism gradually faded away as the seventeenth century came closer to its end. In the eighteenth century, trading houses began to pay more attention to the foundation of a solid business system for the sake of stability, and this was sought through a formalised system of education for household members geared to create the necessary tact, know-how, 
and appropriate 'attitudes' among employees, and to standardise their performance. The common method employed for that purpose was the formation of the family precepts (kakun). Some houses used different names such as tensoku (rule of the shop), tenh $\bar{o}$ (law of the shop), and misesadame (provisions of the shop) instead of the term kakun. [25] Moral and ethical admonitions usually constituted a large part of the precepts, but they also involved descriptions of trade regulations, and 'concepts' and methods of trading. The family precepts of a radical sort, that of the Yano family, for instance, involved specific methods for efficient management, the 'way' to read the market, and secret know-how in dealing. [26] Miyamoto Mataji shows that the employment of the family precepts became almost fashionable in the second half of the eighteenth century not only among the big merchant houses but also among middle and small merchant households. [27]

Of note here is the fact that Shingaku pupils were active in the writing of the family precepts. The following extracts are taken from the precepts of the Omiya trading house in Kyōto, composed by the head of the house, Saito Masakado in 1769. They exhibit Ishida's influence; some passages are quoted virtually verbatim from Ishida's 'Memorandum for the Well-Being of the Household' in Ishida Sensei Goroku, mentioned in the last chapter: 
'1. Needless to say, each member of the shop shall pursue his role to the best of his ability; [in addition,] there should always be mutual assistance in the pursuit of household business; from clerks to apprentices, all shall respect harmony and consort with one another in the household ... If a member be selfish and pursue 'unrighteous' quarrels, that will always be to the detriment of the household ... Members shall always be righteous and be in agreement for that is the way to preserve the well-being of the household.' [article 4]

'1. If the master of the household were not performing his duty, or if there were a need for amendment to the household rules, the problem shall be discussed immediately by all members. The master shall be expostulated constantly for his wrong doing. If no sign of improvement appears, all members shall [consult with one another and] even decide to confine the master; for the continuation of the household shall be prioritised above all.' [article 3]

'1. If a retainer thought that the earning of extra profit even through the deployment of unfair means is a mark of loyalty to one's master, such retainer's thought shall be corrected.' [article 15]

'1. Not to mention a business with a frequent customer, even the sale of a small cut of cloth [with an unfamiliar customer] shall be conducted with a heartfelt care ... A man's business continues through the mercy of the customers; they are like the parents of the business.' [article 17]

The essence of articles 15 and 17 appeared in Ishida's discourse in Tohi-Mondō, and the importance of 'mutual care' was manifest in his 'Memorandum' in the Goroku. The retainer's right to terminate the service of an ill-serving household head is also 
listed in the precepts. Saitō was a merchant who studied under Ishida, and became one of his closest pupils in the final years of his leadership. The following is taken from 'A Provision of Household Business' (Kagyō no Sadame) written by Sugiura Munenaka, and is another example of the influence of Ishida's thought on the family precepts of trading houses:

'... Regarding the 'origins' of the existence of the merchants; merchants exist in order to meet the surplus and shortfall of goods and services; they are entitled to make their living through transactions... To make their fortune through these activities is the way of the merchants. The parents of this fortune are the people ... Be conscious even of a penny, and give a heartful care to the commodity you intend to sell; if you do this, the goods will suit the customer's wishes and will be sold ... Furthermore, the merchants' activities will circulate fortune amongst the people, and profit all corners of society. [29]

As we saw in Chapter 3, Ishida spoke of the functional indispensability of merchants, and also of the legitimacy of the profit made by them. The above passage duly reflects Ishida's those ideas concerning commerce and merchants. Also, eleven short articles followed this passage, their subjects ranging from specific methods of trading and the treatment of house customers to the precepts of the 'righteous way of trading'. [30]

Both Saitō and Sugiura studied in the Shingaku school under the direct headship of Ishida, and one might thus argue that the reflection of Ishida's thought in their family precepts was a natural 
outcome. Its influence, however, extended beyond the Shingaku school: Yura Shichihei of Tanbaya, a cotton wholesaler in Osaka, wrote two family precepts, 'Code on the Way of the Family' (Kafĩ Shikimoku) in 1796 and 'Provisions' (Okite) in 1797, when he handed over the headship of the family to his son, Hisahide. Takenaka reveals that Shichihei's precepts followed those of Saitō Masakado. Twenty-three out of the thirty-five articles of Saitō's precepts were either copied directly or were of the same tenor; twenty-five of the thirty-four articles of Okite, six out of the twenty-seven of Kafü Shikimoku, and two of the four supplementary articles were adopted from passages in Saitō's precepts, according to Takenaka. [31] In later years, Hisahide began to involve himself increasingly in Shingaku and became one of the lecturers at the Meiseisha in Osaka.

According to Miyamoto Mataji's study, the precepts of the Yano family reveal the considerable influence of Shingaku thought, despite the fact that no direct link between the house and the Shingaku school is identifiable. An ethical precept of the house, Enju Hōshinki, stresses such virtues as selflessness, thrift, and recognition of one's role (in both the household and society) and devotion to it. [32] The twenty-fourth and twenty-fifth articles of Monmō Hajigaki, written in 1845, warn against selfish decision-making in business, and stress the importance of 
consultation with other household members and of consensus in both written and verbal means of communication. [33] According to Miyamoto, 'it seems that Shingaku masters wrote the family precepts for various households in townships at the request of those households'. [34] He also argues that 'a fundamental similarity between the ideologies of households and the ethics of Shingaku thinkers is identifiable in numerous examples (of the precepts in various households), and thus the contribution of the Shingaku school in the formation of the 'norm' of the merchants is highly likely'. [35]

Shingaku as a movement declined in the late Edo period. Many of its academic centres were closed down in the years from late Edo to Bakumatsu, especially the ones in the economically difficult Kantō region. However, Shingaku thought, particularly the thought on work developed in its founder, Ishida, formed an intrinsic part of the precepts of trading houses.

Shingaku masters maintained their contact with trading houses even in the modern Meiji era. A prime example is their association with the Sumitomo family, a mercantile giant of the Edo period, which grew to become zaibatsu conglomerate in the Meiji period. One of the executive members of the Sumitomo family, Kokura Masatsune, began to employ Shingaku teaching for the education of the Sumitomo employees in the early Meiji 
period. Kokura continued his association with Shingaku, and later became the president of the Sekimon Shingaku Association in the post-war year of 1952. [36] 
PART III NINOMIYA SONTOKU

$-119-$ 


\section{Introduction to Part III}

Ninomiya Sontoku, as a representative of agrarian leaders working for the rehabilitation of villages that had been deserted in the late Edo and Bakumatsu eras, is a figure of considerable historical importance. Like other rural leaders and technologists, he was a man of common origin who lived most of his life in villages. He held governmental office at both national and provincial levels, but his chief concern lay not in politics but almost solely in the improvement of economic conditions in the villages, some of which had reached a desperate state by the beginning of the nineteenth century, particularly in the northern Kantō region. Ninomiya is also important as a popular thinker who represented the new thrust of thought on work and the economy which emerged in the late Edo period. Although he was not a vanguard representative of the commercialisation of the agrarian economy, he played a critical role in accumulating underlying ideas of agricultural work to which he added ideological meaning, and in feeding this back to the agrarian commoners of the era. He was the founder of the movement for agricultural rehabilitation - later called the Hötoku movement which spread extensively in the Kantō region in the first half of the nineteenth century, and at a national level in the subsequent Bakumatsu and Meiji eras. 
Ninomiya was born in 1787 into a farming household in Kayama, a village in the domain of Odawara, Suruga Province. Kayama village was approximately three miles north of Odawara (town), the principal castle town of the domain. The household to which he belonged had two cho and three tan of wet paddy, a considerable area of arable land for a farmer to hold. His family was one of the richer peasant households in the region, but the great flood in the early 1790s destroyed all its fortunes: the Ninomiya family into which Sontoku was born was a branch family, newly established by Sontoku's grandfather. As was often the case with new families, the Ninomiyas' paddy and house were located not on the ideal side of the village, but alongside the bank of the River Sakawa, and were vulnerable to natural disasters, particularly floods. [1] The great flood of 1791 swept away the entire land area belonged to the Ninomiyas. What was even worse, Sontoku lost his father, Riemon, when he was thirteen, and this was followed by the death of his mother two years later. Sontoku and his two younger brothers were left to fend for themselves, and experienced a time of extreme hardship.

By 1810 , however, he had restored his farmland and his household, thanks to help from relatives and by dint of his own efforts. The restoration he undertook was recognised by the domain of Odawara, and the domain, looking for a 'good model' 
of diligence with which to admonish its peasant producers, awarded Ninomiya for his efforts. He was employed by the domain in 1811 as a member of a restoration project for the Hattori family, one of the retainers of the domain lord, Okubo. In 1816 , he began in the service of Ōkubo Tadazane, the Lord of the time, and immediately joined domainal village reconstruction programmes. Two years later, he was appointed the leader of the Hattori family project, an unusual honour for a person of agrarian origin. In 1822, at the age of thirty-five, he was appointed the leader of the village rehabilitation programme in the domain of Sakuramachi in Shimotsuke Province. From then on, he devoted himself to the rehabilitation of deserted villages and domains in the entire northern Kantō area. He was also in charge of similar projects in more far-flung domains, such as Sōma in the Tōhoku region.

Ninomiya became a retainer of the Tokugawa Shogunate (bakushin) in 1842, and participated in the project for the refurbishment of the bank alongside the River Tone. Even after he left Government office, he continued to serve village and domainal projects until he died in 1856 at the age of seventy at the administration office of the Nikkō project. He was involved in as many as twenty-three village rehabilitation projects in thirty-four years. Including the villages which employed Ninomiya's schemes 
but had no direct contact with him, the total number of the villages affiliated with Ninomiya is believed to have reached six hundred. [2]

Ninomiya's adolescence was thus devoted to the restoration of his own household, and the rest of his life was spent in the restoration of deserted villages and domains. He had no formal instruction or academic education, except for a few opportunities to get acquainted with Neo-Confucian teaching from domainal lectures when he was serving the Hattori family in Odawara. This fact is responsible, in turn, for the construction of his thought, which was marked by its practicality. As we will see in the next chapter, agricultural topics predominate in his theoretical accounts. He used words and phrases from Neo-Confucian rhetoric, and even used Neo-Confucian diagrams to express his ideas, but they were all related to the productive work of agriculture. Although his thought may not be as intellectually refined as other Tokugawa schools of thought, the actual influence it had on the rural populace, and its contribution in restoring village morale and agricultural productivity cannot be discounted.

Ninomiya produced several written works in which his thought on work, society and nature was expressed. But he was not a thinker who composed theory only; he also formed the village rehabilitation programme called shiho, in which he 
specifically designed work in actual terms. Since he expressed his idea of work in two different modes - ideological 'discourse' and the economic measures of the shiho programme - and the level of thought in each differs, we need to deal with them separately. The following chapter discusses Ninomiya's thought on work as expressed in his philosophical writings. His ideas as reflected in the workings of the shihō programme will be dealt with in Chapter 7. The findings of the two chapters will be consolidated and the impact of his work thought on the economic activities of the peasants of the era will be analysed in Chapter 8 . 
Chapter 6: The idea of work in the thought of Ninomiya Sontoku

The philosophy of work (1): Virtues of industry and planning

The title of Ninomiya's main treatise, Sansai Hotöku

Kinmōroku (abbreviated as Kinmōroku hereafter), illustrates his idea of nature, man and work: Sansai means 'three abilities', which were the abilities of Heaven (ten), earth (chi), and human beings. The title literally means 'the use of the three abilities of Heaven, earth, and man as recompense for the virtues received'. 'Virtue' as it is used here has little to do with moral excellence or righteousness. As we will see in this chapter, it refers to the 'gift from nature' given to man in one form through the birth of ancestors, and in another form through the consistent supply of 'sources of life', such as the soil, water, and seeds: nature provides man with these natural gifts. The physical birth of man is brought about by his parents, ancestors, and, in an ultimate sense, by nature. A living man's existence has been made possible by the diligence and industry of his ancestors in bringing to fruition the natural gifts. Living human beings, the product of both nature and the predecessors, are obliged to work hard in order to continue and further cultivate the received virtue (natural gifts). This act, in Ninomiya's view, corresponded to remuneration for the blessings received from nature. 
Kinmōroku appeared in 1834. Its content comprises revised versions of manuscripts and jottings written in his diary in an informal manner mostly in the 1820 s and early 1830 s, when Ninomiya was vigorously involved in village projects. Kinmoroku was, in other words, a culmination of his thought as it developed concurrently with his idea of work and the economy during the course of the actual village rehabilitation processes. Ninomiya's written works, Kinmōroku and others, are all preoccupied with words that enhanced man's industry and planning within an agricultural context due largely to this fact. The following words and diagrams were taken from the Tenmei Shichigenzu of 1836 , which encourages man's industry:

Diagram A: Riches and Poverty

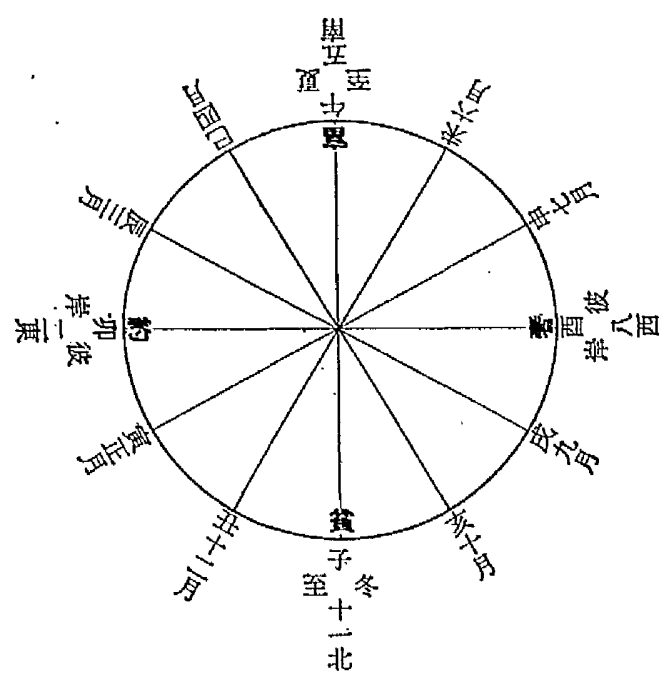

Diagram B: Fulfilment and Loss

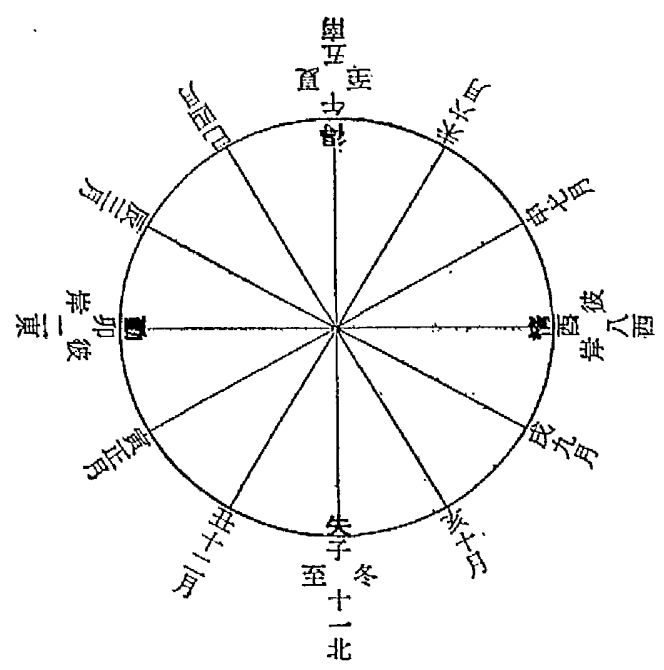

[2]

'... If you practise frugality and economy, you will be rich; if you indulge in a luxurious life you will be poor. For years, this law will never be changed or 
reversed.' [1] '... If you are industrious, you will acquire prosperity and be fulfilled; if you lose your industriousness you will lose prosperity. As such, this law will never be changed or reversed' [2].

In the diagram of riches and poverty, yaku (約 = frugality) is placed along with 卯二月, February in the old calendar, which is the beginning of spring, and with 東, the 'East', the direction of the rising sun. Tomi, wealth and/or abundance, is placed with 午五月, May, the beginning of summer, and with 南, the 'South'. Ogori (素 = extravagance) is placed with autumn and the 'West', and hin （資 = poverty） with winter and the 'North'. Ninomiya compared the cycle of riches and poverty to the seasonal ups (summer) and downs (winter), and with the compass; frugality leads to the season of abundance (summer) and extravagance will result in poverty (winter). Similarly, he composed a diagram of fulfilment and loss. Tsutome (趿 = industry) is the beginning of fulfilment (得 = toku or $e r u$ ), while indulgence (惰 $=d a$ or namake) will result in loss (失 $=$ shitsu or ushinau). For Ninomiya, economic ups and downs depend on the degree of industry, and on the amount of frugality practised. He also stated the following:

'Wealth and poverty both exist in human society. One might think this is accidental, but it is not. There is always a cause for this difference. Wealth resides with a frugal man; it disintegrates if it resides in an extravagant man ... Neither wealth nor poverty is caused by accident.' [3] 
In Ninomiya's view, people were not destined to be poor or rich by force majeure; industry and frugality could overcome even difficult circumstances and bring about fortune. Moreover, he did not just limit himself to preaching admonitions for industry and frugality. Specific formulas for efficient production were devised as follows:

Diagram C: A Labour Plan (daily production schedule)

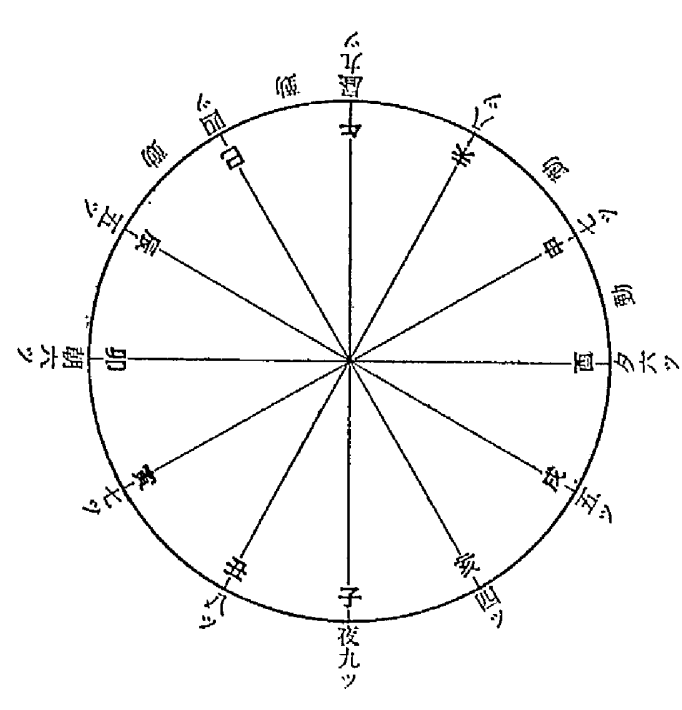

[4]
Diagram D: "Ten's Order of Annual Yield" (annual production schedule)

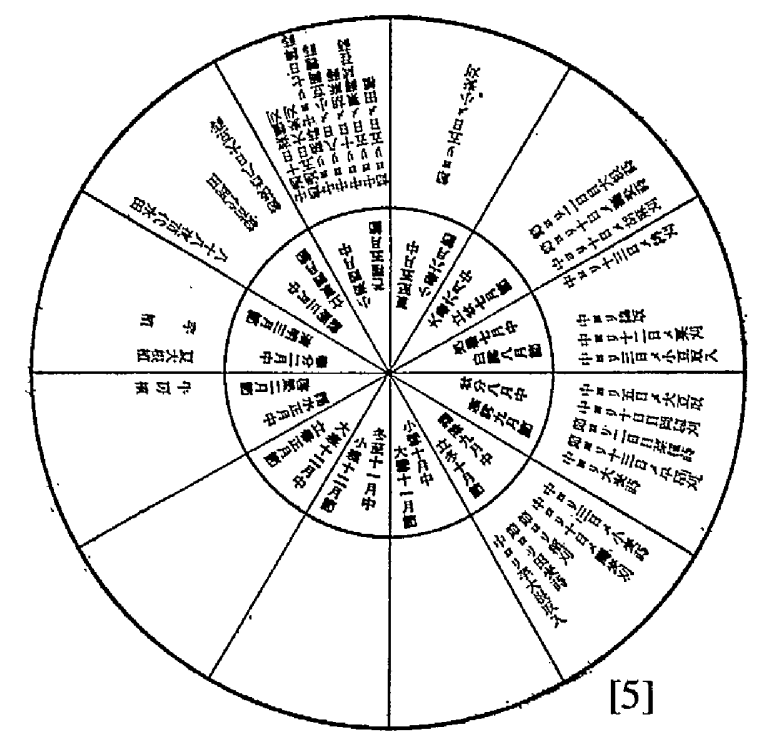

'Deduct muttsutoki of night time [approximately half a day] from jyuunitoki [twenty-four hours = one day]. Within the other muttsutoki, you have your breakfast between sixth time [muttsudoki] and fifth time [itsutsudoki] in the morning. You should work for two toki; one in between fifth and fourth times [itsutsudoki and yottsudoki], and the other between fourth and ninth times [yottsudoki and kokonotsudoki]. You have your lunch break at ninth toki, and have a rest until eighth toki. You should work for two toki again; between eighth and seventh, and seventh and sixth toki. From the sixth toki in the evening to the sixth toki in the following morning, you have a rest. In total, you have hattoki [approximately sixteen hours] of rest hours and yontoki 
[approximately eight hours] of work hours in a day. Within one year [four-thousand three-hundred and twenty toki], you will rest for two-thousand eight-hundred and eighty toki and work for one-thousand four-hundred and forty toki [two-thousand eight-hundred and eighty-hours]. That means, 33 per cent of your time will be spent working, and 66 per cent resting' [4]

Yontoki is about eight hours on the present day-scale. According to this daily production schedule formulated by Ninomiya, peasants are advised to work at least two different times a day, making a total work time of approximately eight hours per day. [6] Work hours are also calculated on an annual basis. The length of work time and the number of tasks to be dealt with vary according to seasonal demand. Collective and lengthy work is carried out in peak seasons. Work time also varies due to the expansion and contraction of one toki, the length of which differs according to the length of daylight hours; night-time toki expands and daytime toki contracts in winter and vice versa in summer. However, it is important to note that, in this standardised daily work schedule, time is objectified and represented in a diagram, and used to constitute an ordered formula for everyone to rely on when dealing with productive activities. Ninomiya also devised a diagram for annual yield (Diagram D), which set out seasonal yield in a form that could provide the basis for a yearly work schedule. In other words, the productive cycle of nature was not just viewed as a 'natural occurrence' but was assimilated in 
diagrammatic form and used as an invaluable source of information for judicious task organisation and production scheduling, that enabled man to manipulate time in the elaborate process of multi-crop production; man was no longer merely submissive to time and the 'rhythms' of nature.

Agriculture involves interaction with nature, which requires man to follow nature's rhythms. But such 'scheduling devices' as Ninomiya's diagrams enable the distribution of labour timing to facilitate complex crop rotation systems, with which man can maximise the potential productive capacity of nature. The industry in agricultural production which Ninomiya advocated represented not merely an increase in the amount of 'labour input', but the execution of appropriate 'management' involving accurate estimation and planning; it was a 'plan rational' industry geared towards efficiency. His shihō programme, which will be examined in the following chapter, was the culmination of this feature of his thought; it was a programme for production improvement, formulated with well coordinated absorption and utilisation of labour, finance, and other resources with a view to efficiency maximisation.

It is to be noted that time specification and its management at the hands of peasant households was already becoming an integral element in agricultural work by the early stages of the Tokugawa 
period. T.C. Smith argues that knowledge of farm management and planning were apparent already in the Hyakusho Denki of 1680. The assertion of agricultural knowledge and well-timed planning were a dominant feature of agricultural treatises ( $n \bar{o} s h o)$, which appeared in abundance in the late eighteenth century. As a crucial element in the promotion of efficiency in production, Smith argues that 'time was regarded as fleeting and precious, and great moral value attached to its productive use.' [7] The prevalence of this concept of time certainly enabled Ninomiya to instil into the peasants the concept of planning as a decisive factor in production increase.

Thus, a well-organised and ordered industry, as well as frugality were, for Ninomiya, the key faculties to overcome the force majeure of nature and to make one's living. Ninomiya also emphasised the continuation of industry and planning for successive generations for the sake not only of individual prosperity but of the well-being of the household. As was seen in Chapter 2, the Japanese household developed as a unit of agricultural production as well as an entity of perpetual continuum with which its members identified themselves. According to Ninomiya, initiatives in industry and planning were to sustain this perpetuality. The following diagram, called Hötokukun, is taken from Ninomiya's Kinmōroku: 


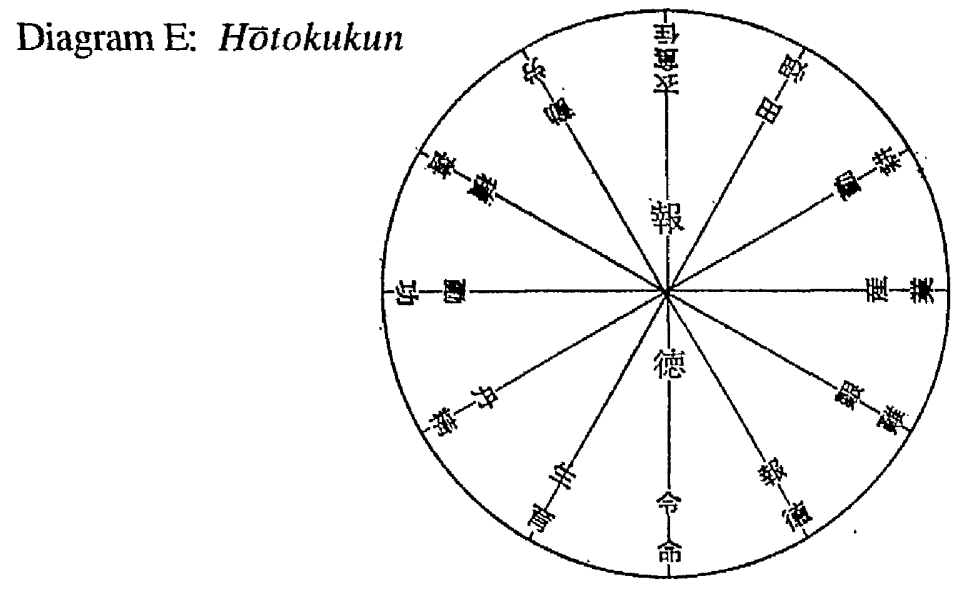

[8]

'The origin of parents is to be found in the will of Heaven and earth [令命]. The origin of a human being is found in the birth and care [生觔] given by the parents. Succession to children and grandchildren depends on the parents' whole-hearted devotion [丹錹]. The prosperity of parents is brought about by their ancestors' industry and accomplishments [勤功]. Our prosperity is brought about by the "accumulated goodness" [皘善] of our parents. The prosperity of descendants is dependent on our (present member's) efforts [勤学]. Our own growth and prosperity depend upon the following three things: clothing [衣], food [食], and shelter [住]. These three necessities are realised by paddy and field [田烟], woods and forests. It is our diligence in cultivation [勤耕] which brings these to fruition and nurtures ourselves. The yields of today are brought about by the productive act [産業] of yesterday. The yields of next year will be brought about by the exertions and hardships [勤難] of this year. Do not forget your duty of giving recompense for virtues received [報徳].' [8]

Human beings receive virtue from Heaven and earth in one form in the birth of parents (ancestors), and in another in the supply of soil, water, and seeds - the sources of existence. Human beings in turn are to formulate plans, and invest manpower to make the best possible use of these received virtues in order to 
nourish themselves and to maintain the prosperity of the household. Moreover, the life of the present members is dependent on the accomplishments of the ancestors, and the 'accumulated goodness' of the successive generations. Industry, predecessors' devotion, and 'good deeds' were not merely to promote the prosperity of a person or a generation but acted as 'cumulative agencies' for the successive betterment of the prosperity of the household. Present members were obliged to fulfil their part through industry in order to participate in this cumulative effort for the benefit of future generations. What Ninomiya advocated here was not that the succession of the household should be based upon the repetition of a simple reproductive process. He placed emphasis on the betterment of the household, and its accumulation of economic prosperity, which was not only to benefit one generation but to foster the household's ascendance for generations. The creative force of nature, the industry of the ancestors, and the diligence of the present members were all unified in this continuous act. The concept of industry was not only central to this interactive process, but was dependent on it. Industry was encouraged because it promotes the well-being of the household, and constitutes the virtuous act. In this way, ie ideology became inseparable from economic activity; in turn, the ideology incorporated economic rationale into its organisational 
principle.

The other notable element in the diagram of Hōtokukun is its amalgamation of physical deeds and spiritual affairs. Such physical deeds as 'productive act' (産業), 'diligence' (勤労・勤功), and 'nurturing' (生育) are emphasised in the diagram, while it also advocates 'sekizen' (皘善 = "accumulation of good doings") and ' $h \delta$ toku' (報徳), recompense for virtues received. Ninomiya is here relating agricultural work to the cultivation of humanity, a peculiar element of his thought being the constant dialogue between economy and humanity, and the mental and physical worlds, without losing sight of the importance of efficiency.

Ninomiya's thought appears contrastive to mere intellectualism. On one occasion, Ninomiya attacked Confucianism for teaching empty courtesies which did not provide the populace with any means of enriching themselves. According to 'Sage Ninomiya's Evening Talks', edited by Fukuzumi Masae, a Ninomiya disciple, Ninomiya wrote:

'In Confucian teaching, you are taught not to see, listen to, speak of, or act upon anything not associated with courtesy [rei]; in real life, however, the practice of courtesy alone is not enough; I thus advocate that you do not see, listen to, speak of, or act upon anything which does not benefit yourself and people; I decline to believe anything, even the teachings in the classic texts, unless it provides people with actual benefit.' [9] 
Neo-Confucianism aimed, as we saw in Chapter 3, to cultivate self, and so influence and transform society and the cosmos. It certainly aimed to 'benefit' self and society in this respect. However, the thought system prescribed the means of cultivation only for the elite population, while it prevented the masses from any prospect of becoming active participants in cultivation. Moreover, neither contemplative means nor scholarship could serve to improve the economic conditions of the Kanto villages where Ninomiya spent a considerable part of his life. The villages had suffered serious economic decline. The orthodox measures advocated by Confucians, and the more scholastic methods of Neo-Confucianism, were alien to productive action of any sort, and could do nothing to ease the peasants' predicament. The sole means to alleviate those chronic conditions was the provision of practical devices to bring about the rehabilitation of the economy. Ethical teaching had to be geared toward activating the economy, not observing courtesies. In the following passage, Ninomiya castigates the son of a wealthy farmer. The son was to be sent to Yushima Seido at Edo to study Neo-Confucianism, but Ninomiya accuses the son of becoming involved in the meaningless study of intellectualism and admonishes him on the importance of 'practical learning': 
'However rich a farmer may be, he must have a good knowledge of agricultural affairs, and whatever amount of gold a rich man may possess, he must lead a life of thrift and industry and concede whatever possessions he can spare, so as to enrich and beautify his native place ... ... You engage in your studies with the overwhelming idea that agriculture is a low occupation and a farmer is a lowly person, the learning you acquire will make you still more vainglorious, and there is no doubt that you will finally bring ruin to your house ... Even were you to continue to study [at Yushima Seidō] for the rest of your life, you would never be able to see this truth.' [10]

In Ninomiya's view, practical knowledge, which was mainly concerned with the promotion of agricultural production, was of the utmost importance. The scientific observation of things and its practical use in agriculture, these were what enriched individuals, the household, and society as a whole, not the practice of courtesy and righteousness.

The philosophy of work (2): Concepts of Tendö and Jindō

Ninomiya viewed the cycle of nature as a continuous process of creation. In his philosophy, this process was termed Tendō, which literally means the 'Heavenly Way'. Kinmōroku includes a diagram of the Great Ultimate which illustrates Ninomiya's idea of creation inherent in the Way of Heaven. Banbutsu Hatsugensh $\bar{u}$, 'Collection of Ninomiya's Words on Things', sets out his discourse on the 'chain process of creation' brought about by Tendo: 
Diagram F: Great Ultimate

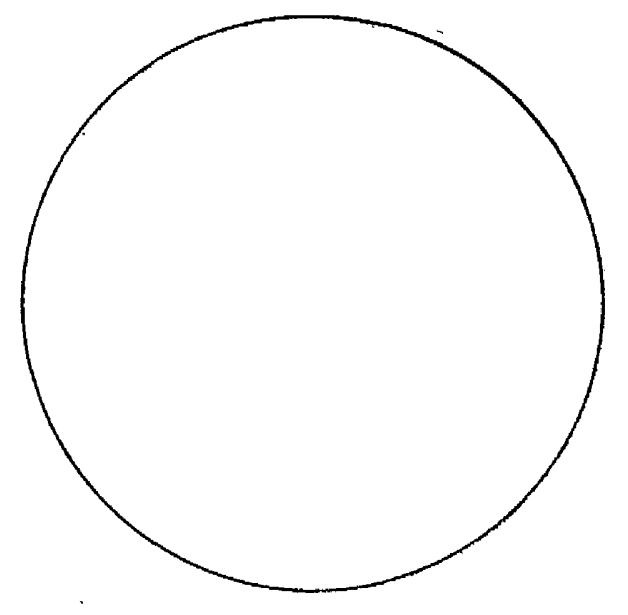

[11]
Diagram G: Development of the World

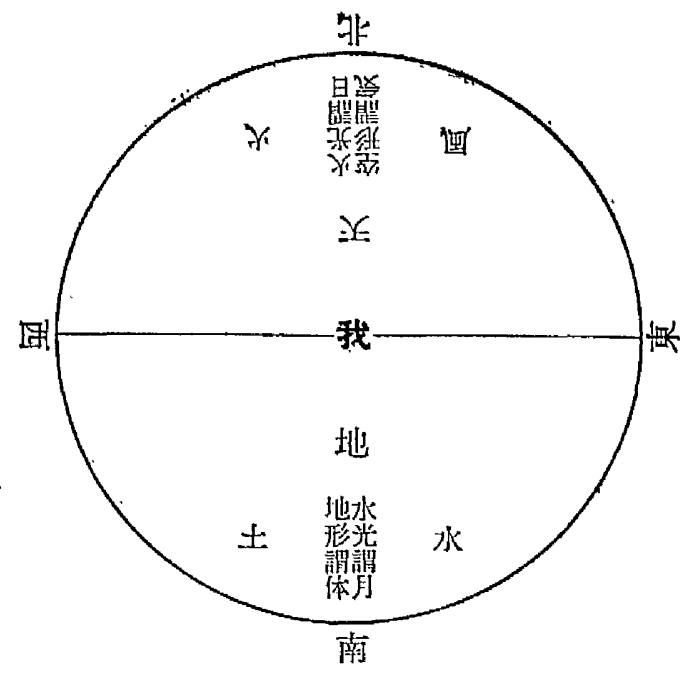

[12]

'No creature can be born without the force of the 'source of all lives' - the Great Ultimate. It has been said that the Great Ultimate was at the beginning a nebulous entity without a division between Heaven and earth, nor was there a division between yin and yang; it was like an egg. [11]

The diagram of the 'Development of the world' illustrates the separation of Heaven and earth, the creation of such life-forces as wind, fire, water, and soil, and the emergence of man (我). A more specific assessment of the development of life is given in Banbutsu Hatsugensh $\bar{u}$ :

'... The sun shone and rain fell, and moss grew on the earth; it was the first living thing on the earth; it withered in the autumn; but the withered moss nurtured the soil, on which grass could grow; grass withered in the autumn; then trees grew because of the soil enriched by the grass; small animals emerged, thanks to the nourishment of the fallen leaves of the flora; . . next, these small animals nurtured birds and beasts; . . . all the flora come out in the spring; they 
all wither in the autumn ... ' [13]

The seed [実] is the will of Heaven [Tenmei] itself; the continuation of Heaven's will [seed] is the tree and grass; its flourishing is the flower [華]; its culmination is the seed [実].' [14] 'If one sows rice, it grows, flourishes, and culminates in rice. If one sows wheat, it grows, flourishes, and culminates in wheat.' [15]

Diagrams $\mathrm{H}$ and I: The creation of Living Things
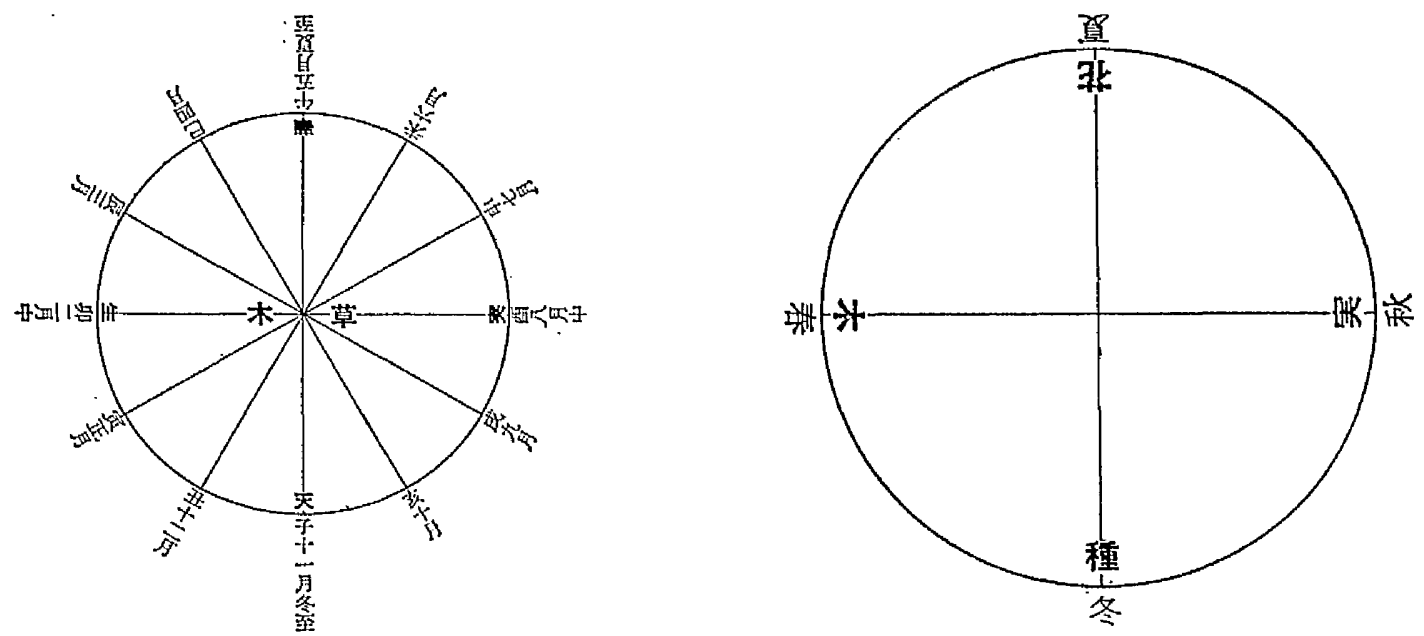

[14]

[15]

A creature flourishes and dies in accordance with the seasonal changes set by nature (the will of Heaven). On the one hand, a creature reproduces itself; on the other hand, the life-force of a creature nurtures another creature of a superior rank into fruition. Ninomiya spoke of the successive and cumulative ascendancy of the household in his Hōtokukun. Similarly, he argues here for the cumulative betterment in the creative cycle of nature; a creature's death contributes to the growth of a creature of a superior rank, and this cumulative cycle spirals upwards. Calamities in the cycle 
of nature not only brought about the extinction of creatures but also brought about the creation in one way or another.

Nature, however, turns out to be destructive to human beings

if left uncontrolled. Man must thus accurately assess the conditions of nature, implement tasks in an ordered form, and make tireless efforts to maintain prosperity. For Ninomiya, the pursuit of such planned industry represents Jindō, the 'Humanly Way', as against Tendō, the 'Heavenly Way':

'The Sage says that Tendo is the way nature arbitrates and works; Jindō is the way which is to be pursued [intentionally] by human beings. The two ways shall not be confused and seen as the same 'way': Jindo is to be sustained by a human's intentional efforts so as to meet Tend $\bar{\sigma}$ ' $\mathrm{s}$ [natural] undoing force. If human beings failed to do so, the force of Tendo would destroy river banks, dry up rivers, destroy bridges, and ruin houses. Jindō should be pursued [by human beings] in order to erect river banks, regularise the flow of rivers, mend bridges, and build houses ...' [16]

Ninomiya distinguished Jind $\bar{o}$ - human beings' constructive action - from the natural way of Heaven, as has been clarified by Maruyama Masao in his classic study. [17] Ninomiya's thoughts on the separation of the two Ways marks an ideological departure from orthodox Confucian teaching, which recognised human beings' existence and actions as 'given' or 'natural', and advocated efforts to conform to nature as the 'supreme order'. Ninomiya's strong emphasis on man's initiative, interpreted here as man's 
efforts in agricultural and other development projects, expresses his sensitivity to man's subjectivity in production.

Ninomiya, however, viewed nature - the Heavenly Way - as a supplier of 'virtues' on the one hand, and as an 'undoing force' on the other. It might seem hard to reconcile his bipartite view of nature, but this contradiction serves to legitimise his emphasis on industry and planning: natural calamities occur with no regard for human desires. Man has to plan ahead in order to avoid possible disasters. Nature on the other hand prepares the 'seeds of prosperity' for life, but the seeds would never be brought to fruition without consistent industry and appropriate planning by human beings. Ninomiya upheld man as an entity capable of activating the creative capacity of nature to the maximum degree. But man by no means possesses the ability to dominate nature. $\mathrm{He}$ attempted to clarify this point, and illustrated the action to be taken by man with reference to the motion of a hydraulic turbine:

'Sage says that Jind $\delta$ is . . like [the motion of] a hydraulic turbine; half of the turbine is in the water, and moves along with the flow; but half of it remains outside, and going in the opposite direction. If the entire turbine were in the water, it would be washed away; if no part was in touch with the water, it wouldn't turn ... The same applies to agriculture: land may be covered by weed. This is what Tendo brings about. A man has to cut the weed and develop the land. Tendo also provides us with the opportunity to grow grains in the spring. We follow these blessings of Tendo and sow seeds. We follow Tendo on the one hand, and go against it on the other. 
This is what Jindo is all about. [18]

Thus, Ninomiya in no way suggested the domination of man over nature, although production initiatives within the creative fabric of Tend $\bar{o}$ were vigorously encouraged. People suffer famines because of their ignorance of nature, their lack of awareness of its movements, and of the efforts they should make to respond to it. With the investment of an abundance of human resources, the potential of nature can be taken advantage of and even increased. Ninomiya stated that,
'A land is, no matter how potentially rich it may be, useless without the developing force [of human beings]; paddies and ploughlands are useless fields without peasants ... It is the effort of human beings that brings about crops; a man shall note this point and devote himself extensively to the development and cultivation of the land.' [19]

The philosophy of work (3): Production as shinden kaihatsu As it appeared in the diagram of Hōtokukun (Diagram E), man's industry in agriculture is related to spiritual betterment. The diagram of the 'virtue from the paddy' (below) correlates the cultivation of humanity with the pursuit of agricultural production: 
Diagram J: The 'Virtue From the Paddy' as the Source of Humane Life

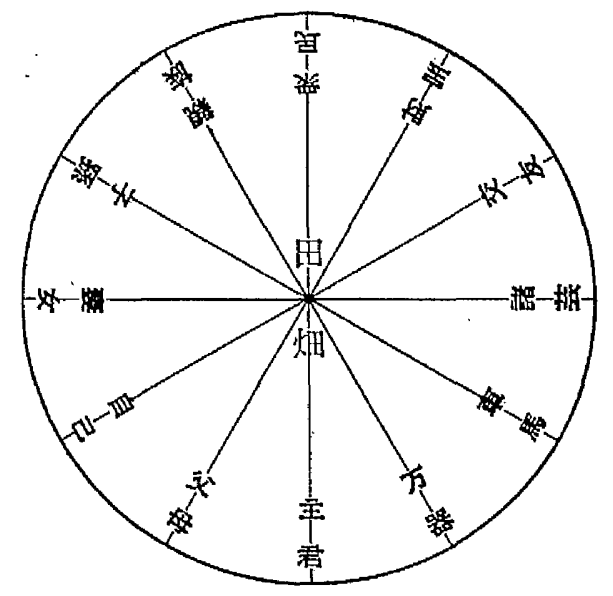

'... If there is no paddy, no living things [human beings] could grow.

There is [human] life because there is a paddy and field ... People can all live because of the virtue from the paddy. Because of that virtue, fortune grows, humane intercourse between friends develops, and people maintain their belongings. Without a paddy and field, no one can pursue a humane life. Cultivation of land has thus continuously been pursued from the era of Amaterasu in Japan, and from the era of Yao and Shun in China. The heralds of the gods took the initiative in agriculture, and let people learn agriculture. None of us should forget this. [20]

Ninomiya speaks here of agricultural work and yield, and its importance as the source of fortune, prosperity, and every human relationship. Yield - the basic constituent of humane life - was regarded by Ninomiya as 'virtuous'. Virtue refers to physical gifts from nature in his main treatise, Kinmōroku. Here in the above passage it effectively means yield. The concept of virtue is intermixed with agriculture and its product, and one's extensive involvement in agricultural production is the source of every 
human fortune, and the 'way' which leads to humanity. On the other hand, he argues in 'Evening Talks' that a cultivated human heart would bring about the cultivation of the land, and ultimately the prosperity of the nation:

'Desolation of various kinds is caused fundamentally by the desolation of the human heart. My task thus starts with the cultivation of this battered human heart [shinden no kaihatsu]. If the heart is returned to good, paddy and field will be reclaimed. Through a succession of reclamation efforts, a nation will easily be strengthened.' [21]

'... My aim is to cultivate the desolated kokoro no ta [the 'paddy of the human heart]; sow the paddy [heart] with good seeds such as jin, $g i$, rei, and $c h i$ which we received from Heaven, harvest good seeds from the paddy [heart], and sow them again ... When a desolate man's mind is cultivated, thousands of acres of paddies and dry fields can be developed without any difficulty. [22]

An abundant yield brings about humanity; the refinement of the human heart brings about the development of paddies and dry fields. While no orthodox method such as meditation or investigation was emphasised for the cultivation of heart in Ninomiya's thought, agricultural production in an ordered and calculated form was directly linked to the cultivation of inner self. He also attempted to diffuse this thought to the masses through waka (the 31-syllable Japanese ode). The following are thought to have been composed by Ninomiya in 1832 : 
'Hōnen no aki no monaka no maki-doki wa, hotoke ni masaru satori narikeri'

'Sowing of wheat in the autumn of a fruitful year; it will lead you to spiritual enlightenment [satori] more than to the level attained by Buddha.' [23]

'Maki uete tokini tagayashi kusa kirite, minori matsu mi wa tanoshi karikeri' 'Sow the land with seeds, cultivate the land, and mow the grasses; you labour, and wait for a fruitful harvest. You are blessed with joy on that very occasion.' [24]

Ninomiya composed waka on various occasions, as a vehicle for his thoughts and often included them in correspondence with his people. The rhythmic waka made it easier for the populace to remember the content, and as a means of transmission it was far more effective than an admonitory discourse involving difficult words.

Ninomiya identified agricultural production as an act through which 'virtuous interactions' between Heaven, earth, and human beings were to be executed. And that was seen as the source of humane living and the continuous prosperity for generations. It was however not a mere input of 'labour' which Ninomiya emphasised in the execution of that virtuous act; he referred to the management of time, labour allocation, and judicious planning to fully activate the productive potential of nature, not 'hard work' alone. It was the consolidated action of the creative forces of 
nature, the industry of ancestors, and the diligence of the present members of the household that actualised the building of cumulative prosperity. 


\section{Chapter 7: The shiho programme}

1) The economic setting and the programme

Ninomiya not only expressed his thought on work in written form but designed and organised work in the actual village rehabilitation process. He composed and implemented the shiho programme [1] which demonstrated the close relationship that existed between his thought and economic reality. It is this relationship that distinguishes him from other thinkers and explains the high level of practical influence his thought gained.

This chapter analyses four main features of a comprehensive shiho programme implemented in the domain of Sakuramachi (a domain in northern Kantō): (1) the investment of capital, the mobilisation of financial, land, and other idle resources; (2) the incentivising and training of labour; (3) the improvement of technology; and (4) the provision of social welfare. Amongst the economic measures which comprised these four elements, the most influential ones in the development of the perception of work were:

a) The fiscal reform package, namely, the setting of bundo and suijo (to be discussed in section 2-1). The package was designed to impose strict financial control upon both the proprietor and the peasants. It clarified the demarcation between 'subsistence' and 'surplus', and helped cultivate a sense of financial planning in the 
minds of peasants.

b) The way the injection of start-up capital was made; loans were offered not to the domain proprietor alone but also to the household producers. The households were attempted to have been made financially semi-autonomous entities responsible for their own production (section 2-2).

c) Communal schemes; organised labour projects for land reclamation and infrastructure development were carried out, often involving intra- and inter-village task-forces (section 2-4). Projects were financially assisted by the capital which was communally pooled and controlled. This capital was also used to finance the collective purchasing of tools and fertilisers, and the poor-saving schemes (sections 2-2, 4-1). These measures helped develop communal sensitivity in the pursuit of work.

d) Introduction of an award system. This promoted competition among villagers and raised the overall standards of work intensity (section 3-1). At the same time, measures were taken to aid the poor peasants by integrating them into the economic fabric of the village (section 5-1). The sense of 'competitive cooperatism' was promoted in the minds of peasants.

e) Ninomiya's educational efforts during the process of village rehabilitation cultivated productive and managerial initiatives among peasants in the pursuit of their work (section 3-2). 
As we shall see later in this study, shihō achieved a significant degree of success in rehabilitating villages in the domain of Sakuramachi. Such economic measures as the mobilisation of capital not only increased work opportunities but gave greater opportunities for technological improvements; and, through it, work took on greater variety and complexity. The deployment of such economic measures, in turn, enlarged the scope of work. On the other hand, such opportunities were taken up only where peasant producers were able to respond to them. What we are concerned with here is this process of correspondence between the economic measures applied and the peasants (the subject of work by whom the measures were effected).

It is not possible here to analyse the form work took before the implementation of the shiho programme (we may call this the 'base structure' of work). But given the fact that shiho was successful, it would be reasonable to assume that there was a meaningful set of interactions between the economic measures employed and the base structure of work of peasants, during which process the economic measures successfully drew out the villagers' economic capacities, and, a new, more institutionalised structure of work emerged. This new structure (or new 'form') set out clearer reference points for peasants in their perception of work. In other words, the shiho programme provided them with a framework 
within which work was carried out, and thereby institutionalised the structure of work. The purpose of this chapter is to define this institutionalised structure of work which Ninomiya attempted to create through the implementation of the economic measures included in his shihō programme.

[1-1] The village economy in early nineteenth century Japan Before entering into the details of Ninomiya's shihō programme, it may be appropriate to sketch the village economy of the late Tokugawa era, and in particular that of the northern Kantō region, in order to identify the economic factors which were responsible for the emergence of the programme. The first half of the nineteenth century, particularly the period after 1820 , was marked by an overall growth of economy in national terms. [2] The population started to increase after experiencing steady decline throughout the eighteenth century. [3] Agricultural production also grew, owing in part to the increase of arable land area, but mainly to the growth of land productivity as a result of the increased use of manures and fertilisers, the introduction of fertiliser responsive and high-yielding seed varieties [4], the spread of double cropping [5], and the further intensification of labour in response to these technological advancements. [6] The penetration of the agrarian economy by commercial institutions in urban areas 
was as intensive as ever. It stimulated the rural proto-industrial development started as nokan yogyo in western Japan in the second-half of the eighteenth century. It began to spread to the east, and the provinces of Shinano, Kōzuke, Iwashiro, Musashi, and Kai in eastern Japan, for instance, became leading regions of raw silk production by the middle of the nineteenth century. [7] Income per capita grew steadily due both to the increase in agricultural production and to the flourishing of proto-industry. [8]

On the other hand, the domains generally suffered from chronic budgetary deficits throughout the second half of the Edo period. Their revenues were no longer secure in an era of ever-increasing economic dynamism; inflation alone caused serious financial difficulty for samurai. To counter the difficulty, the domains attempted to carry out fiscal reform, or, so-called hansei kaikaku. Some attempted to increase their revenue through financial reform, the implementation of domain-scale cultivation and land-reclamation, and, notably, the encouragement of special local production (tokusan). Tokusan varied from the making of wax, paper, and ceramics to cotton manufacturing in western domains. Several domains in the Tohoku region specialised in silkworm growing and silk reeling, and other textile industries. [9] But there were many domains which could not afford such 
forward-looking plans. Most of the domains in the northern Kantō region possessed neither advanced technology in agriculture nor substantial proto-industrial output, even in the early nineteenth century. Domain officials, alienated from the land and without any experience of agricultural production, often turned to the more educated agricultural technologists such as Ōkura Nagatsune. Alternatively, they turned to the Shingaku school to raise the peasants' morale [10], even though 'moralistic' measures alone were not effective in promoting productivity. [11]

\section{[1-2] The northern Kantō villages in distress}

The northern Kantō villages without substantial growth in either agricultural or proto-industrial output were drawn into the nationwide extension of commercial economy. [12] At the same time, the region was hit by the great famines of Tenmei in the late eighteenth century and of Tenpō between 1833 and 1839 (the severest damage was inflicted in 1833 and 1836), which were mainly caused by cold weather. The severity was reflected in population decline, revealed in a study by Sekiyama Naotarō. The overall population in Japan decreased slightly from $26,065,425$ in 1721 (Kyōho 6) to $25,086,466$ in 1786 (Tenmei 6), and then increased to $26,602,110$ in 1822 (Bunsei 5). Sekiyama's index on the Kantō region shows a decline from 100 (1721) to 85.40 
(1786), and to $82.81(1822=$ Bunsei 5). [13] The decline was far sharper in the northern Kantō region. The index shows that the population in Shimotsuke Province declined from 100 (1721) to 77.4 (1786), and to 61.1 (1834). Hitachi Province's population declined from 100 (1721) to 72.2 (1786), and to 64.2 (1834). [14]

Famines decimated the population in the northern Kantō region, which further deteriorated its production capability. To counteract this vicious cycle, measures were finally taken by domain administrators of the region in the form of a 'village rehabilitation programme by the head of the domain' (ryōshu shiho), which consisted of land reclamation and infrastructure development projects, and a scheme to increase the population. Typical examples included Mōoka Daikan Shihō, which started in the Kansei era (1789-1800), and the ryōshu shiho in the village of Nishi Takahashi. Ninomiya's Sontoku shihō retained some elements of the ryōshu shihō. [15] But Ninomiya's (Sontoku) shihö was decisively different from that of the domain: its primary aim was not the increase of the domain's income, but the nourishment of villages and households; for instance, Sontoku shiho was designed to limit the revenue of the domain and to return the surplus to peasant producers for their reproduction purposes. This not only helped struggling peasants but motivated them to work. 
Tokugawa agriculture, even that in the most advanced areas, was marked by labour intensity. Given the abundance of labour and the scarcity of land, successive technological advancement centred around labour intensity, and required individual peasant producers to work even longer hours, be equipped with better technological knowledge, and invest tireless effort in producing with limited land resources. Labour saving technology did not develop substantially even in the advanced regions of western Japan in the first half of the nineteenth century. [16] Given that technological peculiarity, success in agriculture depended on the intensity of the peasants' labour and 'care'; each worker's care, knowledge, and initiative were seen as vital factors for successful production.

This peculiarity in the form of Tokugawa agriculture was closely linked to a fundamental cause of the economic decline that occurred in the Kantō villages from the late eighteenth century onwards. The devastating famines were certainly a major cause of economic stagnation in the villages, but one needs to distinguish between the 'triggering' cause and the 'substantial' or 'real' cause, which was a deterioration in the nature of the peasants' 'attitude' towards work. A positive approach was indispensable for this form of labour intensive agriculture. Kaihō Seiryō (1755-1817) illustrates the atmosphere in the Kantō villages thus: 
'People in Bushū [the Province of Musashi] tend to be lazy [zurukegachi]. They are not like the people in the five provinces of Kinai. Lazy men are always negligent. They prefer eating dull food without work to producing good quality food through work.' [17]

Musashi was one of the provinces in the Kantō region. The difference between the people in the Kantō and the Kinai in terms of 'attitude' to work is clear in Kaihō's statement. This fact, in turn, suggests that the restoration of the Kantō villages did not have to be accompanied by measures involving massive investment, i.e., investment in such labour-saving technologies as heavy machinery, a large number of domestic animals or tools, usually too costly for poor domains to afford. Village restoration could be sought through providing the idle labour force with incentives, and nurturing their ability to manage the production processes of their own. Ninomiya's shihō programme consisted of such measures.

\section{[1-3] The case of Sakuramachi}

The domain of Sakuramachi in Shimotsuke Province, approximately 100 kilometres north of Edo, was the place where Ninomiya's shihō was implemented for the first time in 1822. Like other domains in the northern Kanto region, it had been suffering a severe decline in production. It produced more than $3,000 h y \bar{o}$ of rice per annum in the late seventeenth century, but a 
succession of great famines reduced the productivity severely, so that in the early nineteenth century it was producing less than 1,000 hyō per annum. There were 433 households when the Utsu family, a branch of the Ōkubo family of Odawara, was posted to govern the domain in 1698. But the number of households had declined sharply to only 156 by the time of Ninomiya's survey in 1821. [18]

Sakuramachi consisted of three villages: Yokota, Tōnuma, and Monoi. The domain was governed by Utsu Hannosuke when Ninomiya started his preliminary research in 1821 , and had been in a chronic economic difficulty for years. It was constantly being given financial and other assistance from Odawara. Ninomiya, having already been recognised by Lord Ōkubo Tadazane through the former's success in the Hattori family's financial project in the late 1810 s, was considered suitable to lead the Sakuramachi restoration project. He was officially posted to the domain in 1821. [19] He was sent to Sakuramachi only as a village headman (nanushi) from Odawara, but given a mandate to run the rehabilitation project himself. He did not receive any instructions from Odawara; nor was he under obligation to report on progress to the domain. He had sole power to control and utilise the surplus from the yield. Okubo appointed Ninomiya the sole delegate for the next ten years, and promised that he would not be brought 
back to Odawara whatever might occur during that period. [20]

2) Capital investment, the mobilisation of capital, land, and labour resources

[2-1] Fiscal reform

The chief aim of the comprehensive shihō programme was the recovery of production in rice and other crops. Equally important was the establishment of a financial system that would ensure a consistent supply of self-generated capital for investment. Only by attaining both, Ninomiya believed, could the domain secure its succession. The first and the most immediate task of the shiho programme was financial rehabilitation.

First, Ninomiya submitted a statistical report to the Utsu family in order to make his case. The project started with a preliminary investigation carried out in 1821 (Bunsei 4), one year prior to the official start of the programme. Production studies, including assessments of labour, land, and equipment resources, were conducted in that year. Annual output was calculated for the previous ten years, between 1812 (Bunka 9) and 1821. A document called Goshuhō Gododaikin Heikinchō [21] was produced late in 1821 , which showed the yield of each village in the region, including local grains (zakkoku). In the early Edo period, Sakuramachi was considered to have produced nearly 
4,000 koku of rice per annum. The production record book, Kokin Seisui Heikin Dodaichō, [22] of the region suggests that as much as 3,116 hyō of rice was produced annually between 1698 and 1716. But Ninomiya and his shihö group's study shows a quite different picture; an average of 962 hyō of rice and 130 ry $\bar{o}$ worth of other crops were produced annually between 1812 and 1821 . [23] The cultivability of the entire land area in Sakuramachi was studied and reported on in 1821 , and the outcome officially recorded in the Kaihatsu Denbata Tanbetsu Hikaechō of 1824. It shows that there was $226 \mathrm{ch} \bar{o}$ and 1 tan of wet paddy, but land under use consisted of less than half of this; only 104 chō and 1 tan was under cultivation. [24] On the basis of these studies, Ninomiya concluded that the domain's feasible production level was 2,039 hyo - an average of 3,116 and 962 . The official report including these figures was submitted to the Utsu family in the form of the Shuhō (Shihō) Dodaichō in 1823.

Secondly, Ninomya distinguished between 'subsistence' and 'surplus' to make a case for capital accumulation, and conceptualised it with such terms as bundo and suijo. As we have seen, the 'sustainable level of production' was determined on the basis of average productivity and investigation of land feasibility. It was, in Ninomiya's view, the 'given capacity of production' (tenmei shizen no bun) for the region. Based on the production 
estimate, a set of financial plans was formulated. Financial control based on the foregoing calculations was called bundo. The proprietor of a village or a domain was to observe bundo. Individual households were also instructed to calculate their 'given' capacity, define bundo, and observe it:

'A nation, a province, a district, a village, and a household . . . each of them has its own stipend [based upon its productive capacity]. This is the 'given' [capacity] of nature. Determining one's expenditure based upon given capacity is [the setting and observation of] bundo ... If one strictly observes bundo, a surplus [yozai] will begin to appear, and will enrich the nation and the people.' [25]

This passage is from the 'Memoirs of Teacher Ninomiya', a collection of his thoughts expounded during the shiho programme. Ninomiya argues the need for financial control in each household, so that each could make a consistent self-generation of capital.

Once this bundo was met, and surplus had begun to appear, the next stage was to accumulate the surplus. A scheme to meet this end was called suijo, and the accumulated capital was pooled and controlled under the direct supervision of Ninomiya and his shiho leaders. The accumulated capital was called Hotokukin (the Hōtoku Capital) and used as principal to buffer any shortage of food supply caused by poor crops, to loan capital to peasants struggling without any start-up funds, and to invest in new facilities such as tools and fertilisers, and in the development of 
infrastructures.

These devices, however, did not end up with the provision of a systematic model for capital accumulation and investment; since bundo and suijo were to be practised by all members of the village, they helped develop financial awareness and a sense of long-term planning among peasant producers. Whether or not the schemes were successful in cultivating peasants' financial awareness and their willingness to practise their own financial control could be judged from the result of the shiho programme; for the continuation of the programme - and the sustaining of the village economy - depended totally on the consistent practices of bundo and suijō by individual peasant households, through which the self-generation of capital for reproduction was realised. Indeed, as tables 1 and 3 suggest, shihō showed an overall success in rehabilitating the villages. This fact in turn suggests that the necessary capital had been reproduced, and the programme could continue on that basis. It would therefore be safe to assume that the schemes successfully cultivated the financial awareness of peasants. The attitude of peasants in maintaining bundo is also clear from the letters written to Ninomiya from peasants in 1829 :

'From the peasants of Yokota village, Zenzō, Yasugoro, Genzo, Kōuhachi, and Uhei: We were able to restore our village through the implementation of the shihō programme, which was carried out under your [Ninomiya's] instruction ... All five of us will eagerly maintain our frugality, maintain 
our bungen [bundo] assigned to us, and be diligent in agriculture ...'

[26] (10 letters of similar content were sent in April, 1829 alone.

Four of them were from the ordinary peasants.) [27]

This is the letter produced after a small rebellion organised against Ninomiya by a group of peasants in 1828. [28] The ordinary peasants, not only village headmen, wrote directly to Ninomiya expressing their willingness to observe the fiscal reform package.

\section{[2-2] Local credit facilities}

The Hotoku Capital amounted only to 71 ryo at the beginning of the Sakuramachi project, but it had reached 10,000 ryō by the time the Nikkō project was started in 1853. The Capital enabled indebted peasant households to release themselves from difficult financial situations. [29]

Those households which borrowed from the Hōtoku Capital were expected to repay the money in annual instalments, which were usually spread over five years. They were also required to pay back 'blessing money' (myōgakin) as an expression of 'gratitude' for the loans after the completion of the yearly instalment payments, the amount corresponding to one year's instalment. However, the Hōtoku Capital loan system enabled indebted peasant households to enjoy virtually interest-free loans for the instalment years. In addition, the Capital was offered 
without any security or mortgage, which made funds available even to struggling peasant households. [30] Loans at the initial stage were all recorded in Tōza Kingin Deirichō, Tōza Kingin Kome Zeni Deirichō, and other record books in 1823. [31] Sasai calculated that the amount spent in assistance for each household reached 168 ryo; loans totalled 27 ryō. Expenses for fertiliser, tools, and rice were also covered by the amount. [32]

The loans saved peasants from economic difficulties, but more importantly, allowed them to maintain their own households and thus retain their economic as well as ideological integrity, the very existence of which was the source of household members' identity and motivation. Indeed, as mentioned in Chapter 2, the household became a semi-independent unit of agricultural production during the course of Tokugawa economic evolution. In the shiho programme, most of the loans were allotted to the head of the household $(k a c h \bar{o})$ to allow this unit to enjoy a relative

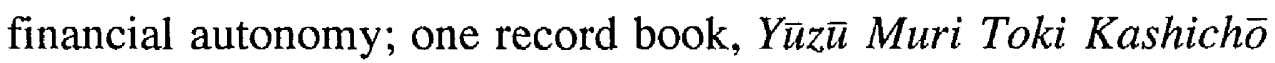
of 1824 , for instance, shows that fifteen out of eighteen loans were offered to the household head in the village of Tonuma, and one to the leader of a 'quasi-family' unit in the village. [33] In short, Ninomiya did not attempt to abolish the autonomy of the households by concentrating power and financial capability in the hands of the proprietor. Rather, each household was offered loans 
in order to sustain its financial capability, and thereby the fundamental necessity for autonomous management of production was met.

[2-3] The rehabilitation programme

Despite all the financial schemes, Sakuramachi did not have the financial capability to support these schemes when the programme was launched in 1821 . The income of the domain of Sakuramachi was determined at 2,039 hyō; however, for a domain which had produced an average of only 962 hyō per annum for the last decade, 2,039 hyō per annum looked unachievable. To counter the initial difficulty, Ninomiya employed two emergency measures: first, he lowered the income of the domain for the next ten years in order to make investment capital available. Shuhō (Shihö) Dodaichō of 1823 states,

'For the next one decade [until 1831], the amount of tax [gochigyō] shall be limited to 1,005 hyō of rice, 127 ryō worth of dry-paddy products such as soya bean, and other sundry products. Nothing beyond this should be requested.' [34]

1,005 hyō and 127 ryō in fact represented the total yield in 1821 , and were representative of the preceding ten years' production levels. Significantly, this policy limited the 'income' of the proprietor to a level which was possible for peasants to 
produce at the initial stage, thereby returning a prospective surplus resulting from that limitation to peasant producers to be used for reproduction purposes. This 'emergency bundo' imposed upon the proprietor functioned to defend peasant producers from excessive exploitation; returned capital was to be used as Hōtoku Capital for reproduction purposes.

Indeed, as the chart below shows, production rose to 1,326 hyō and 137 ryō in 1822, the first year of the shihō programme, and surplus for suijo began to appear. It rose further to 1,825 hyo and 137 ryo in 1827 , and to 1,987 hyō and 138 ryō in 1834; which accumulated the surplus of 8,543 hyō and 210 ryo in fifteen years. In short, Ninomiya's approach was characteristically rational, and was reasonably close to the modern understanding of macro-economics: by cutting down expenditure for a while, one could restore production activities; once they were restored, such a sacrifice would become unnecessary, and production activities as a tax base would become self-financing; hence one could make the case for initial 'pump-priming'. 
Table 1: Annual yield (rice) in Sakuramachi $(1822 \rightarrow 1836)$

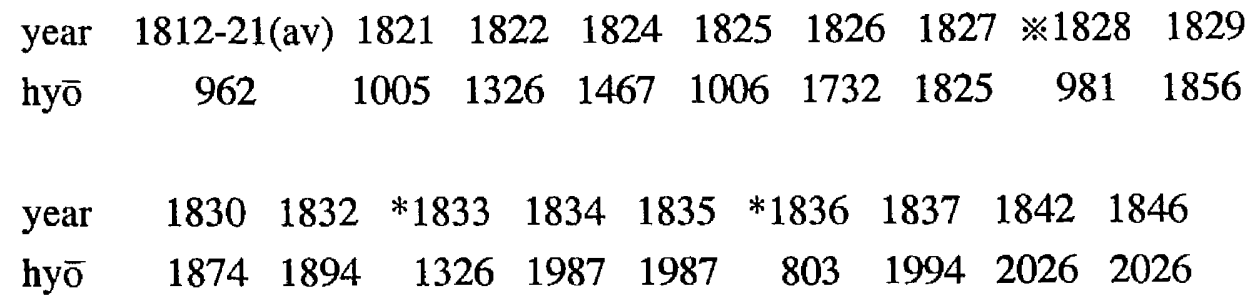

※ year of the 'Toyoda rebellion' [36]

* years of the great famines in the Tenpō era

Second, he pursuaded Odawara to lend initial capital to implement the shihō programme. Cash and rice for the project arrived in October, 1821:

'October, Bunsei 4 (1821).

1. Cash: 50 ryo.

2. Rice: 200 hyō.

Total amount of capital: 112 ryō 2 bu 2 shu 78 mon [ 31.9 hyō of rice was convertible to 10 ryō in 1821].

The above amount of allowance was received [from Odawara]; the received rice and cash will be used to finance loan systems, awards, nourishment, and so on, for the next calendar year.' [37]

Records show that rice and cash to the same amount continued to arrive from Odawara until 1836. Its currency value averaged 144.5 ryō, including the occasional 'additional allowance' in some years: 
Table 2: Rice and cash from Odawara (bun, shu, kan omitted)

\begin{tabular}{|c|c|c|c|c|c|c|c|c|}
\hline ear & 1821 & 1822 & 1823 & 1824 & 1825 & 1826 & 1827 & 1828 \\
\hline ice (hyō) & 200 & 200 & 200 & 200 & 200 & 200 & 200 & 200 \\
\hline vn. rate per 10 ryō & 031.9 & 21.0 & 24.0 & 23.8 & 17.8 & 17.2 & 26.3 & 20.1 \\
\hline sh (ryō) & 50 & 50 & 50 & 50 & 50 & 50 & 50 & 50 \\
\hline otal cash amt. 112 & $.2 \quad 145$ & & 33.1 & $134.0 \quad 1$ & 162.1 & 123.1 & 126.0 & 150.0 \\
\hline ar & 1829 & 1830 & 1831 & 1832 & 1833 & 1834 & 1835 & 1836 \\
\hline ce (hyō) & 200 & 200 & 200 & 200 & 200 & 200 & 200 & 200 \\
\hline n. rate per 10 ryō & $\overline{0} 19.0$ & 16.8 & 19.8 & 12.7 & 12.5 & 12.4 & 15.4 & 8 \\
\hline & 50 & 50 & 50 & 50 & 50 & 50 & 50 & 50 \\
\hline & 155 & 169.0 & 151.0 & 138.3 & 211.1 & 1211.0 & 179.3 & 300 \\
\hline
\end{tabular}

However, the gradual increase in production and the 'lowered rate' of tax enabled Sakuramachi to depend more on the capital generated by its own increased surplus. As is apparent from Table 1 , the amount of self-produced capital surpassed the amount of the allowance from Odawara from the early stages of the shiho programme.

[2-4] The mobilisation of land resources

a) The restoration and new development of arable land Reports on the land were carried out by shihō leaders in 1821 before the official start of the programme in the following year. A report based on the research of 1821-22 shows that more than half of the cultivable area was in fact not in use: 
Area of paddies and fields in total: 501 chō 8 se 20 ho

Paddies: 226 cho 1 tan 6 se 20 ho Fields: (approx.) 274 chō

Cultivable paddies: 104 chō $2 \tan 9$ se 17 ho

Wasted paddies: 121 chō $8 \tan 7$ se 8 ho [39]

These figures suggest the seriousness of economic conditions in Sakuramachi. The following letter from village leaders to Ninomiya suggests that the leaders immediately started to organise a labour force for land reclamation:

'As we attempted to lay out the paddies, we found a considerably large area of field being neglected. A large area of paddies was deserted, and not well cared for. Some areas did not have a water supply ... Some areas can be cultivated, but we also reported that there were deserted paddies . . . The village officials understood this, and agreed to start reclamation projects; officials are vigorously involved in development projects; paddies have begun to be reclaimed gradually, so have the dry fields ...' [40]

The reclamation of paddies and fields was carried out by an organised labour force. The following Kaihatsu Denbata Tanbetsu Hikaecho shows an example of labour force organisation in the Monoi village:

1) Number of workers employed: 29

[amongst the 29] 5 workers are from Den'emon's

24 are collected from the village

Amount of payment spent: 3 bu in cash and 3 to in rice 
The above workers reclaimed about 7 se of Den'emon's paddy in Nishi Monoi. The above amount paid for labour.

2) Number of workers employed: 6

Amount of payment spent: 2 shu 412 mon in cash and 7 shō and 5 gō of rice

The above workers reclaimed about 9 se of dry field. The above amount paid for labour.

Total amount spent for the labourers: 3 bu 2 shu 412 mon of cash and 3 to 7 sho 5 gō of rice

3) Number of workers employed: 15 and a child Amount of payment spent: 1 bu 2 shu 721 mon in cash and 1 to 9 sho 3 gō and 7 shaku of rice

All 15 workers were involved in the development of the wooded area of Heizaemon's land. The above amount paid for labour.

4) Number of workers: 1

This man worked hard to reclaim the dry field. Allowance for saké is to be paid. Amount of payment spent: 515 mon

5) Number of workers: 1

This man worked hard for development projects. Allowance paid. Amount of payment spent: 2 shu

Within 1824 , about 10 chō of paddy was estimated to have been brought back into use. [42] An additional 8 chō 2 tan and 13 ho was reclaimed in the following year. [43] Reclamation seems to have continued at the pace of approximately ten chō per annum.

b) implementation of extra tasks

Task forces were also organised for infrastructure 
development. Roads and bridges were constructed, and new irrigation and sewage channels, and cold water storage facilities were built. Development projects were carried out from the early stages of the shiho programme. Sasai argues on the basis of his study of Ninomiya's diaries and revenue/expenditure record books that the projects started as early as 1821. [44] Records of 1841 (Tenpō 12) are however the only available official records showing details of the actual labour organisation of those projects. The following record discusses a road construction project in that year and the labour force organised to meet the task:

There is a hollow near the entrance to Yokohori village. Water is stagnant there, particularly on rainy days ... It seriously disrupts men at work. The entire area needs to be refurbished, and the following roads need to be constructed: a 75 ke long, 2 ke and 2 shaku wide road to be built near Sugihama woods; a 120 ke long, 3 ke wide, and 2 to 3 shaku high road to be built; . . . overall, a 529 ke long road and four small bridges are to be built ... Labourers are to be collected not only from Yokohori but from Tōnuma and Yokota villages. Labourers are to be summoned also from the following domains: Kuwanokawa village in Kawasaki's domain, and Aoki village in Kawazoe's domain. [45]

The last two villages - Kuwanokawa and Aoki - were not within Sakuramachi. They belonged to different domains where the shihō programme was employed in later years. Shihō in Aoki village started in 1833 after persistent requests from its domain head, Kawazoe Shōzaburō. This suggests that task forces consisted 
not only of intra-village manpower but of resources from other villages where the shihō programme was employed.

Irrigation and sewage channels were also dealt with by task forces. The following is taken from a record in November, 1842:

'Regarding irrigation and sewage channels of this village: due to the drought in recent years, many irrigation channels, usually abundant in water supply, have dried up . . Both irrigation and sewage channels have redeveloped; roads crossing the moors were also repaired. A task force is to be arranged to cope with these problems.

Directors of the task force: Nakaemon of Yokota, Kishiemon of Shimo-Monoi, and two kumigashira from Monoi village.

Total number of labourers to be employed: 158 [46]

The development projects, coupled with the communal financing of these projects, helped to bring about a sense of common purpose. In addition, the projects provided peasants with opportunities to earn extra cash for the speedy repayment of their debts. [47] The projects certainly enhanced the accumulation of the Hōtoku Capital, which in turn encouraged reproduction initiatives. 
3) The organisation and training of labour

[3-1] The introduction of an award system

As we have seen, the shiho programme involved a range of financial and organisational schemes for village rehabilitation. None of these schemes would have been effective, however, if the subjects of work - the peasant producers - had been left untrained. To provide them with incentive, Ninomiya employed a system of rewards. Rice, tools, and money were used as rewards for those who demonstrated outstanding performance. To choose the recipients of awards, Ninomiya let villagers themselves select the hardest workers from their fellow villagers. The system was called irefuda, or 'balloting'. The awards conferred between Bunsei 5 (1822) and Tenpō 14 (1843) are all recorded in the domain's award record book, the Gohōbi Hika Mōshiwatashisho. [48] The following is an extract from it:

'9th day of September, Bunsei 5

According to the regulation set by the shiho programme introduced last winter, outstanding workers are selected from the village. We have already discussed how to select valuable contributors; we have decided to call for a ballot. The following is the list of winners who received 'high vote' [takafuda = received many votes] in this ballot. Agricultural tools are to be awarded to them.

Announcement:

Yokota village

First prize winner: Kohachi a hoe

Second prize winner: Shōjirō two sickles 
Third prize winner: Chu'emon \& Eikichi a sickle each

Sakai group of Tōnuma village

First prize: Ichizaemon a hoe

Second prize: Takeshichi two sickles

Third prize: Sannosuke \& Kitarō a sickle each'

Prizes were also given in the same manner to the workers of the Wada group of Tōnuma village, Monoi group, Shimo Monoi group, and Nishi Monoi group. [50]

'14th day of December, Bunsei 5

The following groups of workers have cultivated a huge area of land by their own efforts. It has been an outstanding effort, and 2 to of rice will be conferred for each one tan-ho they cultivated.

Announcement:

Yahei's group of Tōnuma village: cultivated 9 tan and 1 se-ho 4 hyō 2 to 2 shō of rice to be given to the group

Goemon's group of Tönuma village: cultivated $8 \tan 7$ se and 27 ho 4 hyo 1 to 5 shō 8 gō of rice to be given to the group Tsuneemon's group of Yokota village: cultivated 2 chō $3 \tan 5$ se and 15 ho 11 hyō 3 to 1 shō of rice to be given to the group Hin'emon's group of Shimo Monoi village: cultivated $8 \tan 9$ se and 15 ho 4 hyō 1 to 9 shō of rice to be given to the group

Bunzō's group of Monoi village: cultivated $4 \tan 9$ se and 3 ho 2 hyō 1 to 8 shō 2 gō of rice to be given to the group Heizaimon's group of Nishi Monoi village: cultivated 7 tan 7 se and 29 ho 3 hyō 3 to 5 shō 9 gō of rice to be given to the group'

The ballot duly reflected the villagers' view of who among them had made an outstanding contribution. For those chosen, it 
was a mark of the efforts they had made, and of the recognition of these efforts by their fellow villagers. It would certainly have cultivated initiative, and would have presumably had an effect on those villagers who did not win the ballot. Morita Shiro writes as follows on the 'side-effect' of the ballot system:

'Electing 'outstanding contributors' from the ordinary mass must have drawn every villager's attention. Moreover, reward presumably brought about serious psychological side effects upon those who were not elected. For the villagers, Sakuramachi was the only place where they lived permanently; they knew each other well, and it was impossible to live without frequent intercourse with other villagers, their wives and their children. [A majority would have won at least one reward during the course of the shiho programme, and thus] those who did not receive any reward for years must have been branded as 'lazy men' by their fellow villagers; it must have been extremely difficult to live in such circumstances.' [52]

The awards would certainly have functioned as triggers in raising incentive in individual peasants, particularly those who had worked hard even before the award system was started. However, a more substantial effect brought about by the scheme was, as Morita implied, psychological. It raised not only the work incentive of the particular individual but the standard of performance in the village as a whole. 


\section{[3-2] Education and work initiative}

Ninomiya held no official lecture sessions. But he was enthusiastic about educating the villagers, and many of his words have been collected in pupils' records such as the 'Memoirs' and 'Evening Talks'. He frequently visited the more out-of-the-way parts of the villages, admonished idlers, and rewarded diligence immediately every time he came across it. His discussions ranged from general admonition to specific criticism of one's decisionmaking ability. In 'Evening Talks' edited by Fukuzumi, Ninomiya spoke thus:

The Sage [Ninomiya] says, the ability to make proper decisions [kettei], and care [chüi] are the most important of all. For things can be achieved through the making of swift decisions and the exercise of precise care; even small matters would not be attained if one did not possess these abilities ... [53]

Here he mentioned the ability to make decisions, as well as 'carefulness' in agricultural work. The following is another example from 'Evening Talks':

'Today it is the winter solstice. It is Heaven's will that the night is long at this time of the year. A man may not like it, and he may want to shorten it, but he cannot because it is Heaven's will. A man cannot alter this. However, if he used a cupful of oil . .. and if he - exerting the 'given' ability of man - made a lamp wick thinner, he could surely illuminate the room until daybreak. This shows how important it is for man to execute his 'humanly' [jinji] ability [to contrive] ...' [54] 
Numerous passages of this kind can be found in the 'Memoirs' and 'Evening Talks'. This time, the central issue of his discussion is ingenuity. Ninomiya argues here that man has the capability to modify the energy of nature to meet his own needs. He speaks in these passages of judgment, carefulness, and expediency. Through the provision of production schedules and the fiscal reform package, Ninomiya attempted to teach the peasants to be self-motivated, to design their own work processes, to be cautious in carrying out that work, and in decision-making.

Thanks to both Ninomiya's educational efforts and the provision of institutional devices, the work norm of peasants showed a dramatic improvement in shihō villages. The following letter was sent to Ninomiya from a shihō leader in 1837 , just after the great Tenpo famine of 1836 . It clearly suggests the improvement in the peasants' attitude to work:

'Our village received blessings from the master [Ninomiya]; we were enlightened in the dark night; we were rescued from death; because of these [instruction and education], we became diligent in agrarian work ... Those who used to sleep in the morning now rise up early. Those who were 'unrighteous' are now doing right ... In winter, people are making ropes in their spare time... They work very hard from the early morning in spring ... [55]

Indeed, this is not only illustrative of the peasants' response to instructions from their superiors (shiho leaders) but also of a 
change in attitude to work among idle peasants. They were working long hours, pursuing extra tasks, and, above all, they were beginning to be self-reliant in production both in economic and psychological terms. Ninomiya argued in his 'Evening Talks' that the cultivation of the human heart brought with it the cultivation of land. The above letter suggests that the peasants' potential to become self-reliant, diligent, and plan-rational entities was indeed cultivated.

\section{[3-3] Settlement policy}

The steady decline in production in the pre-shihō era in Sakuramachi caused a drastic reduction in population. As was stated earlier, Sakuramachi consisted of 433 households in 1698, but it had declined to 156 by the 1820 s. Agriculture based upon labour intensity requires an ample population. In Sakuramachi, the decrease in production contributed to a decline in population, which in turn resulted in a further decline in production. An increase in the absolute number of peasants was thus essential in the stricken villages of Sakuramachi. Ninomiya took the initiative to bring in new households to restore manpower. A letter written in 1830 from a village leader in Machiya village in Echigo shows that five households (twenty-four peasants) were brought in from Echigo to Monoi village in Sakuramachi, and to Mōoka, another 
nearby village where shihō was implemented. The households were headed by second or third sons of big households in Machiya village. They were brought in together with their own family members. [56] Settlement policies adapted were recorded in the Ninbetsuch $\bar{o}$ and Iribyakusho Toritate. The poor condition of Sakuramachi initially attracted few settlers, and Ninomiya's attempt to foster immigration was not successful at first. Nonetheless, Sasai's study shows that nearly fifty people were brought into Sakuramachi in the first few years of the project; the records show some successful cases where workers were brought in, mainly from backward areas. [57] Sunpei, a settler from Renga village, Echigo, helped to reclaim some land and a collapsed homestead, and established himself as a producer of thirty-three koku of rice per annum. He came from Echigo in 1823, and had cultivated 2 chō and 9 tan of new areas by the time he left for Mito in 1833. [58]

Ninomiya also took measures to discourage emigration. In 1827, he stated in a letter: 'Both men and women shall not be permitted to marry a person from another village while shihō is in operation ... Villagers shall be strongly warned against moving away, and urged to reconsider.' [59] 


\section{4) Technological assistance and transfer}

[4-1] The organisation of tools, fertilisers and plants

Villagers in Sakuramachi were supplied with capital at the initial stage of the programme. They were also provided with tools, fertilisers, and the necessary plants. Ninomiya purchased agricultural tools in bulk and distributed them to the villagers, thus reducing the total cost of tools, and benefiting poor villagers who could not afford efficient new tools. The purchased tools were also used as rewards for outstanding workers. Nōgu Kaiire Narabini Watashikatacho of 1824 shows that 30 hoes and 40 sickles were purchased, and more than 36 ryō was spent altogether on the tools:

'Purchase and distribution of hoes and sickles [an extract]

Hoes:

4th day of August, 1823

167 mon of cash was spent to purchase a hoe

25th day of August, 1823

$1 \mathrm{bu}$ of cash was spent to purchase 10 hoes

2nd day of October, 1823

1 bu 2 shu and 677 mon of cash was spent to purchase 19 hoes

Total number of hoes purchased: 30

25th day of August, 1823

A hoe was delivered to each of the following villagers:

Sahei, Chūzaemon, Kiyokichi, Kihei, Yū'emon, Jinzaemon, Zenhei, Chūshichi

1st day of July, 1824

The following are outstanding contributors. A hoe will be awarded 
to each:

Kō'emon of Sakuramachi, Magozaemon of Nishi Monoi, Yū'emon of Tōnuma, Chūzaemon of Yokota

Sickles:

4 ryo 3 bu 2 shu and 714 mon of cash was spent on 214 sickles.

They were distributed in the following manner:

71 sickles to Tönuma group 5 to Hin'emon group 3 to Nishi Monoi

The remaining 135 were distributed through Katsumata and Takeda to:

Yokota village [35], Nishi Monoi village [an additional 45], and

Sakuramachi group [55]

Ninomiya sent shihō leaders to buy fertilisers in bulk from the producers. The Shimekasu Hoshika Jyōnōkin Toritatechō of 1824 shows that more than 100 ryō was spent. [61] Ninomiya also arranged the collective purchase of young rice plants and young cedar buds. The Tōza Kingin Deirichō of 1823 recorded that 3 ryō 2 bu and 673 mon was spent on the purchase of young cedar buds that year. [62]

\section{[4-2] Technology transfer}

The nothern Kantō villages utterly lacked technological skills in agriculture, and the economic difficulties of the region were directly attributable to this. Evidence however shows a few instances where Kantō villages attempted to improve their agricultural technology. Nakai Nobuhiko's study of Öhara Yùgaku (1797-1858), the initiator of agrarian reform and the 
founder of the Seigaku movement in Shimousa, shows Ōhara's enthusiasm to introduce 'advanced' agricultural technologies from the Kinai region into the villages of Shimousa. [63] Existing research, however, tends to have ignored technological awareness within the shihō group. As a matter of fact, Sanpei Matazaemon of Sakuramachi was in touch with Ōkura Nagatsune, the famous agrarian technologist of the Bakumatsu era. [64] Sanpei met Ōkura at least three times, twice in 1829 and once in 1831 , and wrote to Ninomiya in 1829 that,

'... Ōkura seemed to me to be a man with exceptional devotion to agriculture. I have already met him, and found him very interesting. He showed me some of his books concerning wealth creation in the household. I bought many copies of them, and also sent some to Odawara. He came back to me two days ago. He brought with him a couple of his newly published works. Detailed explanation was given concerning the use of cole, ...' [65]

One of the books 'concerning wealth creation in the household' was presumably Okura's Nōkaeki, or 'Farm Family Profits'. The other book on the use of cole was Jokōroku, which was on ways to control insect pests in the rice paddy. Sanpei put advanced technological information on agriculture received from Ökura into practice. [66] He not only used technologies in the domain he served (Sakuramachi) but also in other areas where shiho was in operation. Ōkura appeared also in Sanpei's letter to 
Ninomiya in August, 1831. [67]

The acquisition of advanced technology is important in itself, but what is crucial here is the way in which it was introduced and how it spread. Sanpei became a mediator: a person involved in the programme responded to the advanced technology and caused its use to spread without receiving any instruction from Ninomiya to do so.

Advanced technologies were actively spread by shihō leaders in other areas too. The shihō programme was introduced to three provinces in the Tōkai region, Suruga, Tōtōmi, and Mikawa by Agoin (or 'Agui') Gidō-Shōshichi. Agoin did not have intensive contact with Ninomiya at any stage of his life, but he was in close contact with some of Ninomiya's pupils. He introduced such technologies as the checkrow planting of rice and the thin bedding of young rice plants. [68] These were commonly practised techniques in the Kinai region, and were adopted by Agoin for the first time in the Tōkai region. Some shihō researchers emphasise the labour-intensive element of shihō, while neglecting the technological awareness of its leaders. Certainly, even the 'advanced' technologies introduced by Agoin required a heavy labour input, but it should be noted that labour intensity was not the sole ingredient of the improvement in production brought about under the shihō programme. The cases of Sanpei and Agoin 
reveal the technological awareness of the personnel involved in the scheme.

5) Social welfare and village solidarity

[5-1] The inclusion of 'very poor' (gokunan) peasants in the labour force

Sugano Noriko has argued that shihō was successful in rehabilitating the 'middle-class' peasants (chünoso), but it neglected the poorest. Based on her research on the village of Kaneko in Sagami, she stressed that shiho was the cause of the 'dissolution' of the poorest from agriculture and the 'semiproletarianisation' of them. [69] Ötsuka argues that the poorest peasants were not integrated into shihō's developmental projects and were given no reward. In his view, they were basically left out of the rehabilitation schemes of the shiho programme. [70] Both, therefore, share the idea that shiho failed to help those most impoverished, despite its overall success in the restoration of village economy through the revitalisation of the 'middle-class' peasants.

Both views may be considered accurate in pointing out that shiho could not rehabilitate the poorest peasants to the extent that they could establish themselves as semi-independent productive entities. However, one needs to consider the economic condition 
of the peasants in shihō villages. The poorest were not merely facing economic difficulties; what they experienced was not just the change in the 'mode' of production from agriculture to wage earning but the alienation from any means of production. In the face of this, measures had to be taken to rescue the poorest from a disastrous situation. As Sugano herself points out, extra activities for cash earning were promoted by Ninomiya in the village of Kaneko. Coupled with tax schemes (taxation on income from non-agricultural by-employment was surprisingly low compared with that from agriculture) [71], this plan rescued those in most need.

Ōtsuka's findings also need qualification. First, as Ōtsuka's research itself reveals, loans were made available even to peasant households of the poorest rank. They were provided with a greater quantity of rice assistance than those who were better off. [72] The poor could also take advantage of the loan system without providing any security. Second, measures were taken to prevent the dissolution of the poorest peasant households from the economic fabric of the village; the poorest were absorbed as a secondary labour force. For instance, Ninomiya conducted some non-agricultural bywork in the village. In Bunsei 7, he organised a task force for straw mat making [73], which included some of the poorest peasants. Yūemon and Sannosuke, villagers of 
Tonuma, were listed as the heads of 'very poor' households in their village, even in the survey of 1845. [74] Both, however, contributed to the project by making twenty mats. [75] Even the poorest peasants were absorbed into the labour force to carry out secondary tasks at least. [76]

Furthermore, in the daily life of the village, a variety of miscellaneous tasks were available, even for a secondary labour force. The drying of wheat, the peeling of dried beans, and the care of store rooms were tasks for the elderly. [77] The increase in labour intensity and the involvement in extra tasks created a number of miscellaneous tasks in the household. [78] For these reasons, even the secondary labour force from the poorest household was expected to take part in productive activity of one sort or another. Ninomiya's letter to Uzawa states:

'Hōtoku shuhō [shihō] insists on everybody's making an effort; rich and poor, village officials and ordinary peasants, working men and the retired, they are all required to be involved in one kind of task or another, so as to join in the act of creation. One should be loyal to the assignment; not only that, one should be devoted to secondary tasks, and demonstrate frugality, even after one's retirement ...' [79]

As has already been shown in the studies of Ōto and Kumagawa, shihō was designed to help the most impecunious of peasants. [80] The significance of the programme, however, lies in its incorporation of the population into the unitary fabric of the 
village economy. 'Assistance' was given in exchange for contribution, not as a grant to be assumed by the poor. The policy arguably avoided the separation of the poor from the economic fabric, which might otherwise have resulted in the outmigration of the population to urban areas.

[5-2] The nourishment of the future labour force

One of the priorities of the shiho programme was the nurturing of children. Under the programme, children were provided for mainly in two ways: first, Ninomiya established a class for the teaching of reading, writing, and simple mathematics (tenarai beya). A house was prepared specially for that purpose. The education programme was supported financially by the pool money, the Hōtoku Capital. [81] Second, special aid was given to households with more than three children. The aid was offered mainly through rice. [82] The infants, the prospective labour force for future reproduction, were nurtured and educated by the pool money, which derived from the efforts of the village members.

6) A short summary

As we have seen, a number of schemes were employed and implemented under the control of the shiho programme. The 
following is a letter from Ninomiya to Uzawa Sakuemon, a leader of the shihō programme in Sakuramachi, who was later posted back to the domain of Odawara in 1838 to lead the shiho programme there. It lists the deeds implemented in Sakuramachi in somewhat self-congratulatory tones:

'... the average production between Bunka 9 and Bunsei 4 has been studied ... and an economic formula devised ... Not only has reclamation been carried out, and new paddies and fields been developed, but roads were constructed and bridges were erected; men and horses are able to pass by. Ditches and sewers have been dug; banks erected and waterways made. Thorns, reeds, bush clovers have been mowed. Other unnecessary weeds and trees have also been cut down. Land has been raised or lowered wherever necessary. Temples and houses which had been deserted for years have been repaired; neglected branch family members and new immigrants have been brought in. With these new people, new households have been established. They have been provided with agricultural tools and some food supplies. After all the efforts that have been made for over ten years, cultivable land has increased and people have became prosperous. Villages have been restored. [83]

1836 saw the severest famine in the Tenpō era. A letter from Yokosawa, a shiho leader, shows the state of the economy in Sakuramachi in that year:

'...After an intensive implementation of shihō, life in the villages was revived ... We have been astonished by this fact ... Even those that suffered the worst are not starving any longer. The villages are now successfully maintained, which in fact is a rare case in other areas. Years of hard work by the villagers, and your [Ninomiya's] foresight 
and judicious guidance are the factors which have brought about this situation. I heartily admire it.' [84]

As was shown in Table 1, production in the domain of Sakuramachi showed considerable growth in the years of shihō implementation. The amount of rice production increased to as much as 1,825 hyo in 1827. After the settlement of the 'Toyoda rebellion' in 1828 , production began to grow without fluctuation, except in the years of the great Tenpō famines. In 1842, it grew to 2,026 hyō, almost reaching the target of 2,039 hyō officially set by bundo. Surplus accumulated accordingly in the fifteen years of the shihō programme. Ninomiya initially pursuaded the Utsu family to temporarily lower bundo, and the surplus accumulation was realised largely by this political action, rather than by the success of the economic programme. Nonetheless, the accumulation would not have grown without a gradual increase in actual production. By Tenpō 9 (1838) when the economic management of the domain was handed back to the Utsu family, surplus rice accumulation had reached 8,545 hyō. [85] Financial assistance from Odawara was terminated in 1836, and Sakuramachi began to depend on its own production. [86] An official report on the economic conditions in Sakuramachi, Sankason Daishō Hinpu Kurashikata Torishirabe Agechō or "The living conditions in the three villages', which is based on the 
survey conducted in Koka 2 (1845) shows the following picture:

Table 3: The living conditions (of the households) in the three villages (1845)

$\begin{array}{ccccc}\text { very good } & \text { good } & \text { average } & \text { bad } & \text { very bad } \\ 55 & 59 & 15 & 36 & 23\end{array}$

Among 188 households in Sakuramachi, 114 were listed as in 'very good' or 'good' condition, and 15 as in an 'average' condition. While 23 were considered still to be very bad, however, it is significant that nearly seventy per cent of the households were restored to 'good' or at least to an 'average' condition. Bearing in mind the devastated state of the economy in 1821 , this is a remarkable recovery.

In the course of ten years, the annual yield more than doubled, due largely to the restoration of the arable land area, which increased dramatically. On the other hand, the population had increased by only 51 per cent by the 1850 s, from 722 in 1821 to 1,090 in 1853 . [88] There was thus an increase in per capita production. And this was not just the result of the increase in land. It was also attributable to the amount of labour invested per person, technological improvement, and the application of the effective schemes of shihō. Moreover, the development of land resources and agricultural infrastructure was carried out at the 
hands of the villagers themselves. Production increase was, in the end, the fruit of the villagers' own labour.

The implementation of the shihō programme was initially to be of ten years' duration [89], but it was extended for another five years, until 1836 [90] and was in effect even after 1838. The success of the rehabilitation suggests that shihō was indeed an effective programme. More importantly, it proves that the economic measures employed during the process were more than adequate in stimulating peasant work; for the key to success lies not in the programme itself but in its triumph in restoring the 'attitude' of peasants towards work. The educational as well as institutional schemes of shihō were designed to improve the labour and care capacity of peasants, and to nurture them towards an understanding of their own capabilities in the management of household work. Its success suggests that peasants were able to respond to it. One could thus argue that there existed a set of interactions between the programme and the peasants, during which process the peasants' economic potential was sufficiently fulfilled. Bearing these findings in mind, the next chapter will attempt to identify the perception of work that emerged among peasant producers. 
Chapter 8: Ninomiya's work thought and the peasants' perception of work: An analysis

An inquiry was made in Chapter 6 into Ninomiya's philosophical writings through which his idea of work is expressed. In the last chapter, we investigated the shiho programme in an attempt to reveal how Ninomiya effected his thought on work and restored the agrarian economy. New economic measures were introduced under shihō, including the fiscal reform package, through which peasants were made economically competitive and their performance improved. The programme did not, however, involve any economic measures which were totally alien to the agrarian population, and thus the mode of production was not drastically changed. Shihō did not destroy the productive autonomy of the households, but preserved it; the programme facilitated the productive use of technology, labour, and time by the members of nuclear and stem families. Communal schemes regarding saving, development of public facilities, and the helping of the poor were preserved and promoted. Ideologically, the concept of ie appears central to Ninomiya's thought. It remained as the key factor through which incentives for work were given to peasants, and the transgenerational sense of cumulative betterment of the economy was enhanced. 
The implications of all this are obvious: Ninomiya acted as a catalyst through which the prevalent mode of production and ideological constructs of the era were amalgamated, and a more active and structured mode of work produced. His frame of reference included ideology and economy, and through this and his familiarity with peasant producers, the meaning of work was identified. In turn, peasants were able to respond to Ninomiya's intentions, and his ideas on work spread rapidly among the agrarian population of the northern Kantō villages in the late Edo period.

This chapter seeks to articulate the contributions made by Ninomiya in structuralising and shaping agrarian work and the peasants' perception of it. In the next section, we discuss how managerial and technological elements of work came to be incorporated into the peasants' perception of work in shiho villages. It will be followed by a discussion on how these changes were incorporated into existing ideologies and social values. The last section attempts to identify the characteristic features of the idea of work developed by Ninomiya.

The scope of the perception of work

a) The introduction of the elements of management Both Ninomiya's thought and his shihō programme helped 
develop the idea that work involved management of the process of work. This included financial planning and a modern formula for the control of production costs, effected mainly by the introduction of the concepts of bundo and suijo. Subsistence and surplus were distinguished one from the other in order to achieve a consistent supply of capital for reproduction. Peasants were educated to develop time sense, capability in financial control, and the ability to make decisions concerning agricultural production, so that they could foresee and respond swiftly to events. As the following apologue by Ninomiya, collected in the 'Memoirs', puts it:

'On a voyage, you will not be able to get to the shore you intend to reach, if you simply follow the direction of the wind. If you want to reach there, you have to steer the helm [and control], and avoid drifting. One's life is just like this ...' [1]

Here, Ninomiya's apt use of the sailing metaphor effectively expresses his views on the need for management. The moral incentivising of work alone was not an adequate triggering device to develop necessary productive efficiency in nineteenth-century Tokugawa agriculture. Peasants had to be able to take managerial initiatives to organise production processes themselves. Ninomiya attempted to diffuse this idea of work, so that the elements of management were vividly recognised and the peasants' perception 
of work widened to accommodate it.

b) The introduction of the elements of technology

A similar enlargement in the scope of the perception of work occurred at the level of the actual production process. The technological evolution of Tokugawa agriculture followed a path that reinforced labour intensity. Wherever labour and capital were substitutable, the use of labour was opted for, and technology developed on that basis. A crucial element of this technology was, as conceived in the last chapter, the intensity of the 'care' involved [2]; it called for each worker's consistent exertion in close monitoring of plant growth processes, tight weed control, and the timely use of fertiliser and allocation of labour. In a technological environment of this kind, the actual putting into effect of acquired technology rested mainly in the hands of peasants; they were the subjects who responded to practical information, applied it to the production process, and circulated the information acquired during the process of its application that added practical information from the 'user-front'. Ninomiya was aware of this, and attempted to encourage peasants to become active participants in technological management.

The annual production schedule introduced in the Kinmoroku discussed in Chapter 6 contained detailed instructions on the 
specific timing of planting and harvesting, as well as that of seedbed preparation, fertiliser allocation, and so on. Instructions on fifteen different plants were listed as shown in the diagram. [3] But, crucially, Ninomiya not only presented the schedule in a diagrammatic form but also vigorously attempted to educate the peasants in its use. [4] Ninomiya lived in Sakuramachi, communicated constantly with local people, and watched the productive processes of peasant producers closely. The supervisory eyes of Ninomiya or a shihō leader were constantly monitoring peasants' work, and detailed instructions were given wherever necessary. This scheme of things was far removed from that of the so-called technologists, most of whom were more preoccupied with the diffusion of existing techniques than with practically applying and verifying the feasibility of technologies within the economic reality of the work place. [5] The eventual success of the shiho programme illustrates that the elements of technology were made central to peasants' work in the villages where the programme was introduced.

In an ultimate sense, Tokugawa peasants were indeed active participants in the improvement and reshaping of technology itself. T.C. Smith points out that there was a vast network of local agricultural experimental stations in rural Tokugawa Japan, where technologies were adapted to local conditions, information 
exchanged between stations, and applied advantageously elsewhere. He stated, albeit cautiously, that 'invention' was an outcome of successive discoveries of various sorts, and of the constant transmission of them. [6] In view of this, a recent discussion of how users of technology (those who put the technology into practice) contributed to technical development gives us a useful insight here. Scholars of the 'social constructivist' school have paid special attention to the forces that shaped technological change, and emphasised information networks and loops as decisive elements in the development of technology. [7] In their view, technological innovation is not achieved at the hands of particular individuals but through informational interaction. Moreover, the 'users' of technology are the crucial contributors to the 'informational loop', which gives feedback information for continuous technological development. [8]

The 'social constructivists' are mainly concerned with the development of industrial, not agricultural technology; nor have they referred to technological development in non-Western societies. Their findings nonetheless serve to reshape our view of the process of technological development in general. They are particularly significant when one considers the nature of Tokugawa agriculture, in which the heavy involvement of the users of technology was required in the process of technological 
application.

Nowhere does Ninomiya speak of the role of communication in technological advancement. Given the technological character of Tokugawa agriculture, however, the instruction he gave in technological management must have involved communicational elements that facilitated the informational loop. 'Initiative' was to be taken in establishing communication, in which peasant households participated as active co-generators of technological information, and, ultimately, as contributors to technological advancement itself.

The ideological interpretation and its impact

a) The idea of cumulative betterment

The 'perpetual continuation' (eizoku) of the household was highly valued in Tokugawa society, and the meaning of work for the peasants evolved largely from it. Ninomiya spoke of this, and its cumulative betterment, on numerous occasions. He did not see work as a simple reproductive process; nor did he regard it as a means of acquiring material prosperity for one generation only. His idea of work was built around the value system associated with the household, and the village. In his philosophy, expressed in the diagram of Hötokukun, the household was regarded as a medium through which peasants could practise agricultural production for 
cumulative amelioration.

The integration of the ideology of 'succession' into the idea of production contributed to the enlargement of the scope of the perception of work. First, it released the view of work from the narrow focus of individual gain. A man could justify his work through his belief in cumulative betterment and the perpetual continuation of the household. Similarly, a wife could justify her work through her belief that it would improve the welfare of her descendants. Given that the focus of Tokugawa ideology lay around the concept of $i e$, it was essential for Ninomiya to go beyond economic individualism and create a concept of work within which the full benefit of 'self-exploitation' of the individual would be brought about. Second, once this was achieved, both managerial and technological concerns embodied in the perception of work would take on new meanings, and new dimensions: given that the importance of 'successive betterment' in the minds of peasants could be taken for granted, it was much easier for Ninomiya to make peasants understand the importance of economic calculations involving a time span of one generation or more. It was also much easier to make them grasp the importance of the long-term benefits of sharing technology and information. In fact, the whole concept of management and technology was built on the idea of progressive betterment as a goal. 
b) Self-cultivation as work

In Ninomiya's concepts of Tendo and Jindō, agricultural work - the physical act of production - was elevated to the realm of metaphysics. Work became a process that activated the full potential of the creative force of nature, which, in turn, brought about prosperity and humane living. Man's active participation in the creative cycle of nature was encouraged, and was related to the cultivation of land and heart in Ninomiya's advocacy of shinden kaihatsu. On the other hand, an act of a non-productive sort, such as the practice of Neo-Confucian prescriptions for attainment, was dismissed.

So, having been engaged so whole-heartedly in the economic rehabilitation of deserted villages in northern Kantō, Ninomiya was anxious to embed economic rationale within the peasant mentalite. But his philosophies of work projected 'meanings' onto agricultural work in both a physical and a spiritual sense. Production was regarded as the fulfilment of virtue, and the cultivation of land acted as the medium for inner cultivation.

Significantly, this point reveals both a similarity with and a contrast to the thought of Ishida Baigan. Ishida argued that work was the process of the development of self. The language used might differ, but both Ishida and Ninomiya share a similar tenor 
in their thought here. The 'ingredients' of the means of cultivation in the thought of Ninomiya, however, differ considerably from that of Ishida. Ishida argued for the execution of managerial and inter-personal skills to secure the stable continuation of the household. In the thought of Ninomiya, the scope of that management was extended to embrace not only labour resource management but time, technology, capital, land, and other resources. The economic measures developed by Ninomiya were specific and production-oriented, and were accompanied by judicious planning and management. In Ishida's thought, retainers were not merely to be submissive in household business but to participate in its decision-making. But the informational infrastructure on which the decisions were to be made information on resources, capital, and so on - was far more developed and structured in Ninomiya than in Ishida. Thus, both thinkers regarded work as the process of cultivation, but a far wider range of economic forms were identified as constituents of the perception of work in Ninomiya's thought. There is no doubt that one of his major contributions lay in the ideological underpinning of such a redefinition of self-cultivation.

\section{Competitive cooperatism}

Economic historians have focused largely on the communal 
schemes of the shihō programme - such as its financial schemes that aided the hard-pressed peasants. [9] True, Ninomiya employed various schemes to assist these peasants, financially and otherwise, but most of these were launched with a view to activating labour service, not as 'charitable gifts' on which idling peasants could live. Moreover, the 'communal' approach detracted from the other important element of the shiho programme: the enhancement of internal competition within the village. Productivity increased with the use of an award system. This system, in conjunction with the predominant ie ideology and the values centred around that concept, promoted the psychological dynamism of competition between the households in the village, whereby a strong sense of achievement orientation was developed.

Certainly, ie ideology itself was particularistic, in so far as it referred to the succession of a particular household. Thus, it may not necessarily have been oriented to inter-household competition, but it was consistent with the idea of competition and occupied a central place, with a high moral value, in the life of ordinary peasants. When a peasant received an award, that peasant was honoured himself, but at the same time it was the honour of the household to which he belonged. A man without any awards might be 'ashamed' of himself. If so, it was the dishonour of his household as well. Because in many respects the household 
mattered more than the individual, this imposed a great psychological burden on each individual. The award system had so explicitly stratified the abilities of household members in terms of achievement - and thus the competitiveness and economic reputation of the households - that it encouraged the villagers to become competitive. It is thus possible to argue that performance value was brought about by 'generalised particularism'; the particularistic value system centred around ie ideology was 'generalised' by the award system, which had come to generate achievement orientation. The award system itself was a universalistic means which brought about performance values. [10] But it was this generalisation of particularistic values which contributed to the development of universalistic performance orientation. To some extent, these particularistic values referred to goals rather than means, while they did not only interfere with universalistic means, but actually promoted their introduction.

Ninomiya's education of peasants on time consciousness, work scheduling, and technological awareness all contributed to an improvement in performance. In fact, production increase was far more dramatic in the villages where Ninomiya's shiho programme was practised, than in the villages where ryōshu shiho was deployed. [11] It could be asserted that educational efforts made by Ninomiya culminated in the development of the norm of 
efficiency-driven industry.

The 'ie-centred' explanation of the shihō programme, such as Fukaya's thesis, pays insufficient attention to its cooperative elements, namely, intra- and inter-village mutual assistance in the programme. Advanced technologies were not kept within one village but were shared by other villages where shihō was employed. Communally developed pool money (Hōtoku Capital) was used to assist economically burdened households and villages. Labour forces were exchanged between shihō villages. Households that were about to be dissolved were incorporated into the economic fabric of the village. The shiho programme embraced cooperative elements that fostered mutual assistance, without losing sight of the elements of competition. There was a 'structural dualism' of the household and the village, and a sense of competition and cooperation in shihō villages. But the 'ie-centred' thesis failed to recognise the cooperative element of the programme, while the 'communal' thesis overlooked the performance orientation inherent in it.

Ninomiya encouraged peasants to work for the benefit of the household and the village, while selfish acts of production were discouraged. His concepts of Tendō and Jindō encouraged man's initiative in production in accordance with the creative force of Tendō. Peasants were urged to work and to execute their 
managerial abilities, in order to improve economic conditions cumulatively for generations in the future. In other words, it was neither the subordination of individuals to collectivity nor the individualistic conduct of work per se that Ninomiya encouraged; it was one's subjective contribution to the initiation of organised and consolidated action comprising such abilities as calculation, anticipation, and coordination.

Thus, Ninomiya's idea of work may best be termed 'competitive cooperatism'. Improvements in the performance of peasant producers were sought through education, award systems and the integration of peasants into organised development projects; while finance, tasks, and technology were all shared in the village and the domain. The village was activated as the 'production support agency' of each household, which enhanced the competitiveness of the households. In turn, the competitive performance of each household made the communal functions of the village even more indispensable. In this way, the household and the village became interrelated entities which synergistically promoted economic dynamism within the village. 


\section{Conclusion}

In this study an attempt has been made to present the idea of work developed in the thought of Ishida and Ninomiya, and, through it, to highlight aspects of the perception of work of commoners in the mid-to-late Edo period. The two thinkers acted as key vehicles for the social construction of work in two respects: first, they acted as a medium through which ideology and economy were amalgamated, the meaning of work identified and intellectual expression given to it. Work is not an activity with solely economic purposes and meaning; it also embraces social and ideological meanings which reflect the ideas of society. On the other hand, the actual form of work is dictated by economic and technological factors. As we have seen, the thought of Ishida and Ninomiya represented both popular ideology and thought on work in the Tokugawa era, and the actual form of economic activities in commerce and agriculture based on their own work experience. The study of the two thinkers thus enables us to form a picture of the perception of work of Tokugawa commoners, without falling into the trap of politico-ideological determinism, of which some intellectual historians, particularly those who throw light on the linguistic and ritual features of work, appear to be the victims. Second, their own work experience, and the fact that they both had media for the diffusion of their thought - academic centres (bōsha) 
and the family precepts for Ishida and the shiho programme for Ninomiya - suggest that they were in close contact with popular life and work, and were at the centre of the interactive process between commoners and thought. They were prompt to pick up the economic ideas in the popular work scene which usually existed in an intellectually unformed manner, and to articulate them as an idea of work which was then fed to commoners. Measured in terms of their contribution to the social construction of work, Ishida and Ninomiya are of more interest in the forming of an understanding of the Tokugawa perception of work than hitherto believed. Their contribution is certainly far more substantial in this respect than the image formed of them in the Meiji era would suggest.

This chapter seeks to establish the legitimacy and validity of the approach deployed in this study, by locating the thought of Ishida and Ninomiya in the history of the perception of work in Tokugawa Japan. The following two sections discuss the place of the work thought of Ishida and Ninomiya in Tokugawa economic thought in general, and call for its full acknowledgement as a socio-economic force of change. The last section offers a brief account of the development of work thought in the Bakumatsu and Meiji periods. The Hōtoku movement, led by Ninomiya's followers, was instrumental in the successful introduction of 
modern economic institutions and technology.

The idea of work as a force of socio-economic change

As discussed in Chapter 2, work was conceptually constructed in Tokugawa Japan as a 'role' to be played by people in each occupational group, behind which lay work stratification by the status grouping of shi nō kō shō. The status groups had been politically constructed, and their enduring stability was ideologically endorsed by Neo-Confucianism, which provided society with a cosmology and a conception of order. Ishida never questioned the legitimacy of the Tokugawa social status groups. He regarded the assigned work of each occupational group (shokubun) as given, and took it for granted that individual workers had been given assigned tasks to pursue within that sphere. By doing so, he effectively endorsed such a status division. In contrast to Andō Shōeki (1703-1762), a thinker of the same era who spoke of radical social changes [1], Ishida supported the preservation of the existing social order.

Essentially the same observation applies to Ninomiya. The northern Kantō villages suffered chronic economic difficulties during the early nineteenth century. The division between the wealthier and poorer peasants within these villages became increasingly apparent. Ninomiya attributed the causes for these 
difficulties to both the idleness of peasants in dealing with agricultural production and excessive tax demands. He did not see the problem as the result of such economic trends as the commercialisation of agriculture, large landholders' successful marketing of their surplus produce, and town merchants' investments in land, all of which began to undermine the Tokugawa order and stratify the peasantry.

Ninomiya was not the kind of thinker who saw the causes of growing social distress as arising from the discrepancy between deteriorating polity and rising economy. In his view, the existing political and social frameworks were not the cause of economic difficulties. Unlike Kaihō Seiryō, who spoke approvingly of the emergence of the market system and pointed out its disparity with the static Tokugawa political and social system, thus hinting at the need of its reorganisation [2], Ninomiya attempted to establish a system for economic betterment that was workable within the existing political and social frameworks. Neither the thought of Ishida nor that of Ninomiya was designed to politically activate commoners to initiate changes in the socio-political environment from the root. Having focused arbitrarily on the two thinkers, therefore, an inquiry into the emergence of new thought on social and political reforms, such as that developed by Andō and Kaihō, has been excluded from this study. 
Another qualification is that both thinkers were not fully responsive to the economic and social changes taking place in the mid-to-late Edo period. Ninomiya's thought does not represent the idea of work prevalent in the advanced areas such as the Kinai and western Japan - areas where economic activities had been far more commercially oriented than those in the Kantō region. Ishida does not seem to have been fully familiar with trading practices in areas outside Kyōto. In the trading houses of Edo, for instance, the casual, short-term employment of servants and shop assistants was more commonly practised than in Kyōto. [3] Work relations in Edo may have been more contractual than those in Kyōto for this reason. Such a difference in the form of employment might have brought about different ideas concerning work among the Edo merchants from those shared by Kyōto merchants.

Given these factors, this study should not be taken to present a comprehensive picture of the idea of work in the mid-to-late Edo period. On the other hand, these factors do not detract from the fact that Ishida and Ninomiya were among those thinkers closest to the life and work of the ordinary people. In spite of the reservations mentioned above, the two thinkers were able to pick up the undercurrents of the idea of work prevalent among the commoners of the era, undercurrents which developed as a result 
of common work experience, inherited or shared.

Scholarship on Tokugawa history, particularly economic and intellectual studies, has consistently pointed to the development of the ethic of 'hard work' in Tokugawa society. R.N. Bellah's classic work apart, individual workers' pursuit of thrift, diligence and frugality for the sake of the collective interest were assessed by the scholars of Tokugawa history as the ideologically developed social norm, which compelled every member of society to work hard. Quite frequently, both Ishida and Ninomiya appear in these studies as chief figures who were responsible for the development of such a work ethic. [4] Some historians have even interpreted this as the 'origin' of the ethic of hard work prevalent among workers in the business enterprises of modern and contemporary Japan.

It must be noted, however, that the ethic of hard work alone would not have been adequate to meet the necessities in carrying out the ever more sophisticated and complicated economic activities of the mid-to-late Edo period. In agrarian settings, for instance, the successive evolution of a variety of labour-intensive technologies made peasants' understanding of organisation and management of work an increasingly important element of agriculture. Market forces penetrated into the life of the peasant population. Although village boundaries were strictly observed, 
and peasants were tied to the land, it was essential for peasant households to acquire fully the principle of economic rationale. Furthermore, prices tended to rise in the early nineteenth century, and the opportunity for savings and capital accumulation in the era became much greater than in the previous century. There was a need for the peasants to understand the meaning of these developments. Although Ninomiya was not fully responsive to commercialisation, he attempted to nurture peasants as able and efficient managers of their own production processes.

Neither Ninomiya nor Ishida advocated hard work pure and simple; nor did they merely teach the moral and ethical virtues of loyalty and submission to collectivities. They attempted to cultivate the attitude and capacity of common people toward work in the following way: first, both thinkers encouraged the active participation of each subject of work in the designing of his or her own household work. While work was recognised by the two thinkers as no more than an assigned role in a certain intrinsic context, role-play was taken to be neither a worker's passive adaptation to an assigned social role nor his submission to an order given by a superior, where individual workers existed purely as passive followers. Instead, the management of the production process by workers themselves was forcefully advocated. Second, their thought was marked by meritocracy; an incompetent leader 
was to be removed from his position in the thought of Ishida. Actual production increase was the primary concern of Ninomiya in both his thought and his shihō programme. For both Ishida and Ninomiya, efficiency accompanied by wit and judgment, not merely the exercise of hard work as an expression of loyalty, was an inherent element of the role-play. Third, the ideology of succession (and 'cumulative betterment' in the case of Ninomiya) was integrated into the scope of the perception of work. Work was recognised by the two thinkers as one's subjective participation in sustaining continuous prosperity for generations to come.

The interaction of ideology and socio-economic betterment The degree of political influence cast by a thought system over society is not the sole criterion by which the value of that thought should be judged. One also needs to consider the 'social group' over which that thought hold influence and in what way. There are interactions between ideology and society, in the spheres of less politicised, and more mundane aspects of economic and social life. Ishida and Ninomiya acted as key channels for this interactive process.

Ishida, by referring to both the Neo-Confucian concept of self-cultivation and the forms of work in trading houses, raised 
work within the merchant family business to the level of a process of cultivation. His thought provided merchants with a justification of trading and a meaning of work. A merchant's ability to organise the workgroup, manage the work process, and his participation in business decision-making were all identified as important aspects of work. The scope of work was thus enlarged so as to embrace inter-personal as well as managerial elements.

The physical act of agricultural production was related to human development in the thought of Ninomiya. His idea of work encompassed a fiscal reform package, daily and annual production schedules, formulas for extra cash earning, and economic measures which would enhance the competitiveness of peasants' work. These elements became integrated into agricultural production processes, and were recognised as a means of upholding the household and its successive betterment. In this way, the ideological constructs of Tokugawa society became inseparable from the economy for the two thinkers. The valuation of work was backed by a set of ideological principles, which, in turn, intensified the economic activity of the commoners. It was this interaction between ideology and forms of work that characterised the thought of Ishida and Ninomiya; the acceptance of such an idea of work by the commoners enlarged their perception of work. 
True, even before Ishida, there existed ideologies in Tokugawa Japan, Confucianism among them, which encompassed universe, society, and human behaviour, and which also ideologised the everyday work of human beings. One might argue that ideology and economy were inseparable from the beginning, and, as the economy began to become a dominant element of society, 'the frontiers of philosophical enquiry were broadened to include an increasing range of economic issues', and not vice versa. [5] But sublime ideologies remained for the most part the heritage of the intellectual few. Moreover, ideology was never as closely interlinked with the details of everyday work as in the thought of Ishida and Ninomiya. Thus, it was only after the emergence of the two thinkers that work was ideologised in depth, redefined and enriched with meaning; ideology belonging to the intelligentsia could not claim to have had a substantial impact on the everyday work of the populace for this reason.

The intellectual responses made by Ishida and Ninomiya were arguably more fundamental to economic and social change than political reforms, particularly when they penetrated the life and work of the ordinary people. 'Radical' political thought, such as that developed by Kaiho Seiryō, could not claim to bring any immediate benefit to the 'ordinary' life of the masses. Nor could it claim to encompass the need for economic betterment. By 
contrast, the thought of Ninomiya and Ishida can be viewed as an effective force which promoted economic and social change.

\section{The Hotoku movement from Bakumatsu to Meiji}

The immediate concern of this study is the idea of work developed in the thought of Ishida and Ninomiya and the perception of work among the Tokugawa commoners. Examination of the perception of work in Meiji society remains outside the scope of this study. However, the thought of Ishida survived in the Meiji period in the form of the family precepts of trading houses, despite the overall decline of the Shingaku movement from the beginning of the nineteenth century. The Hōtoku movement spread in the Bakumatsu and Meiji periods with even more rapidity in terms of membership growth than in the late Edo. Thus, a brief sketch of the influences of Ishida and Ninomiya, and particularly that of the Hōtoku movement, is given here to assess the significance of the idea of work shown in this study on the modern perception of work.

Ninomiya was successful in educating his disciples, and by the time of his death in 1856 some of them had already established themselves as agrarian leaders in their homelands. Tomita Kōkei, who became Ninomiya's disciple in 1839 , began his career as the leader of the shihō programme in his native domain of Sōma 
(Fukushima Prefecture after 1871) in the Bakumatsu and early Meiji periods. He also compiled Hōtokuki, which appeared in manuscript form in 1856 and was published in 1880, in which Ninomiya's deeds in the course of the village rehabilitation schemes were described. Fukuzumi Masae and Saitö Takayuki came to serve Ninomiya in 1844 . Both recorded Ninomiya's thoughts and deeds during his involvement in village rehabilitations, and later published Ninomiya- $\bar{O}$ Yawa (1884) and Ninomiya Sensei Goroku (1905) respectively. The most notable example of the Hōtoku movement's practical influence was that of the village of Shimo-Ishida in the Province of Tōtōmi, where the movement was introduced by Agoin Shōshichi, and its ideas subsequently diffused to other villages in the Province by such village leaders as Okada Saheiji and his son, Ryoichiro.

Agoin became a pupil of Ninomiya in 1842. He introduced Ninomiya's thought and the shiho programme to Shimo-Ishida in the mid-1840s. In 1847, Agoin and Kamiya Yoheiji, a headman of the village, founded a group to organise the Hōtoku movement. The group was called Hōtoku Renj $\bar{u}(\operatorname{Rench} \bar{u})$, a 'Party for the Repayment of Virtue'. The following is an extract from the Agreement concluded by the members of the group in 1848 :

1. On this occasion we discussed and agreed on the following:

To be diligent in agricultural work from dawn to dusk; we devote ourselves to rope-making and other extra tasks ... we sincerely 
consent to these agreements ...

1. We consistently save for the help of the poor; we strictly observe the principle of Hōtoku ( $g o h \bar{o}$ no suji); and free interest loans will be offered to those peasants in economic difficulty upon consultation and selection by ballot system. Repayment of the loan is requested; in addition, the payment of an amount corresponding to one year's installment, reikin, is also requested ...

1. On holidays, the members of the group will deal with road construction work from early morning; the members will have a rest in the afternoon.

1. One day in every month, we will organise meetings to discuss such agricultural issues as methods of land cultivation and the use of fertilisers. Other issues related to the benefit of the village are to be discussed on those occasions.

We strictly observe the above.

March, Kaei 1 (1848) [6]

(signatures of the members)

In the second clause the observation of the 'principle of Hōtoku' (gohō no suji) is declared. Since the declaration is made in the context of a discussion on financial matters and the loan system, the observation of the 'principle' probably includes that of bundo and suijō, the fiscal reform package introduced in the shiho programme. The content of the Agreement ranges from admonitory words insisting on hard work to a brief description of the Hotoku loan system. It also refers to the general agreement on plans for infrastructure development, the implementation of extra tasks, and the exchange of technological information among the members. [7] The Agreement appears to be consistent with the 
content of the shihō programme discussed in Chapter 7.

Agoin met Okada Saheiji just after the pronouncement of the Agreement in Shimo-Ishida village in May, 1848. [8] As a result, Okada formed a group in his native village of Kurami with thirty other villagers and composed an agreement, virtually identical to that of Shimo-Ishida's, as the creed of the Hōtoku movement in Kurami. [9] By the time Saheiji and company met Ninomiya in 1853 , societies were founded in 32 villages with 419 participants. [10]

In the Meiji period, such a group was usually called Hōtokusha, the 'Society for the Repayment of Virtue'. [11] The movement to form the Society spread throughout the villages in the Tōtōmi and Suruga Provinces, which merged into the prefecture of Shizuoka after 1871. Some Societies were disbanded in the Bakumatsu and early Meiji periods, but the overall membership grew continuously in Shizuoka prefecture throughout the Meiji period. More than 300 Hōtokusha had been founded in Shizuoka alone by the turn of the century. [12]

The agreement (or 'creed') of Hōtokusha set out a system of economic activity similar to that provided by Ninomiya's shihō programme in the late Edo period: diligence was advocated, and this was backed up by economic plans to promote efficiency. Intra-village cooperation was encouraged, and peasants with 
economic difficulties were offered start-up capital. Strict observation of the 'principle of Hōtoku', which included the observation of the fiscal reform package by every peasant producer, was declared. In this way, attempts were made to transplant Ninomiya's idea of work, the economic measures he devised, and the ideological discourses which underlined his economic ideas, to the peasants of the Meiji period. This strongly suggests the scope of influence that Ninomiya's thought had on the commoners' perception of work at the time.

Hōtokusha also proved responsive to the changes caused by market price fluctuation. Shizuoka prefecture specialised in tea production. The opening of ports to foreign trade in the years 1858 and 1859 , and the rise in the price of tea in the external market during the subsequent two decades [13] provided tea producers with excellent export opportunities. But the producers were also hit by recessions between the boom years. Saito Osamu compares the timing of the recessions with the number of Hōtokusha founded, and shows that more Hōtokusha were established in the years of recession than in boom years. He concludes that the Society functioned as the 'shock-absorber' during the economic downturn in the early and mid Meiji period. [14]

In the first half of the nineteenth century, Ninomiya rescued 
peasants from economic disaster by providing them with workable measures for village rehabilitation. This time, Hötokusha provided commodity producers with a 'safety net' to counter the fluctuations in the economy. Whether or not the Society had by then become capable of making a more positive response to market changes has yet to be studied. For this reason, the impact made by Hōtokusha upon the Meiji commoners in shaping their economic thinking, particularly their perception of commercial activities, cannot be ascertained. However, one can at least make the point that the Society had adapted itself to Meiji socio-economic circumstances, and had begun to play its role in an economic setting where the market system was becoming a far more dominant element.

So, it seems that Hōtokusha transformed itself into a mainstream organisation which served the needs of the agrarian population of the Meiji period. True, the Society did not function as the chief agency in the transmission of mechanical and industrial technologies from the West. Nor did it foster 'Westernisation'. But it provided Meiji commoners with institutional devices backed by a set of ideological principles that encouraged the commoners' to look toward economic betterment.

The Hōtoku movement from the 1890s onwards, however, was gradually integrated into a strong sense of nation building, and 
its founder, Ninomiya, was used by the Government as a model to compel people to work hard [15]: Ninomiya was a common man who started out penniless and established himself as an agrarian leader. He was a familiar figure to the populace, and thus was ideal for the Meiji Government to use as a paragon of hard work. Ninomiya began to appear in the textbooks of elementary schools in 1893, and then in the textbooks of 1901, 1904, and 1910. He also appeared in revised versions of these texts. It has been said that Ninomiya and the Meiji Emperor were the most frequently mentioned figures in textbooks between 1910 and 1945. [16] His statue, invariably depicting him carrying fire wood home and studying his book on the way, stood in every elementary school play ground. It was his image as a hard worker that the Government attempted to diffuse. It attempted to encourage the commoners' hard work in support of the national policy of 'enrich the nation and strengthen the military' (fukoku kyōhei). [17]

Ninomiya certainly valued hard graft. However, an important element of his thought had been overlooked in this Government propaganda: Ninomiya's emphasis on management was displaced by a mere ethic of hard work. It was production increase for the betterment of the economic conditions of the peasants themselves that was prioritised in Ninomiya's thought and his shiho programme, despite the fact that such production growth 
might well serve the national interest in an ultimate sense. Instead, the Government's use of Ninomiya only aimed to call for self-sacrifice for the strengthening of the state. [18]

Numerous Hōtokusha were founded all over Japan by the turn of the century. Chūo Hōtokukai, the 'Central Association of the Hōtoku movement' was founded in 1906, and it functioned as the hub of informational exchange between the Societies. A nationwide periodical - Shimin - was published by the Association. [19] It first appeared in 1906, and continued for forty years until 1946 (no publication in 1945). Although the periodical included admonitory articles on diligence and economy, pages were spared to introduce new machines and economic institutions, and to present successful examples of Hōtoku members' deeds in agricultural and other activities. [20] Moreover, each number included at least one article related to topics from abroad: such subjects as agricultural and industrial technologies, cooperatives in Western nations, and their educational systems were discussed. [21]

The central Hōtoku Association was founded by Meiji bureaucrats with the aim of integrating the Hōtoku movement into the national movement for the strengthening of the nation. Some of the articles in Shimin apparently sounded like Government propaganda. While some Hōtokusha at provincial level might have continued to serve the interests of the people, the movement seems 
to have broken ties with its original aims and function; which were, the provision of a workable economic system for the physical and spiritual enrichment of agrarian commoners. 


\section{Notes:}

- Publication dates for the series volumes; the publication date of the particular volume(s) used is listed, except Ninomiya Sontoku Zensh $\bar{u}$, which started publication in 1927 and culminated in 1932, and series volume dictionaries and encyclopedias such as Nihon Kokugo Daijiten (Shōgakukan, 1972-1976) and Nihonshi Daijiten (Heibonsha, 1992-1994).

\section{PART I WORK IN TOKUGAWA JAPAN:}

\section{AN OVERVIEW}

\section{Chapter 1}

1. Roberts, B., R. Finnegan, and D. Gallie, 'The Meaning of Work: Value and Identity', B. Roberts, R. Finnegan, and D. Gallie (eds.), New Approaches to Economic Life, Manchester University Press, Manchester, 1985, p. 459.

2. Joyce, P., 'The Historical Meanings of Work: An Introduction', P. Joyce (ed.), The Historical Meanings of Work, Cambridge University Press, Cambridge, 1987, pp.1-3.

3. Briggs, A., 'Review of Thompson, The Making of the English Working Class', Labor History, 6 (Winter, 1965), pp. 84-91. H.G. Gutman, 'Work, Culture and Society in Industrializing America, 1815-1919', R.E. Pahl (ed.), On Work: Historical, Comparative \& Theoretical Approaches, Basil Blackwell, Oxford, 1988, pp. 125-37.

4. Work does not develop independently of technological and other economic factors. It is thus necessary to look at the 'form' of work constructed by 'economic' factors, in addition to work as a conceptual construct, if one is concerned with work as a social construct. 
5. Yasumaru Yoshio, Nihon no Kindaika to Minshū Shisō, Aoki Shoten, Tōkyō, 1974, pp. 9-10.

6. The word 'hotoku' literally means the 'repayment of virtue'. Ninomiya advocated that human beings received such 'virtuous gifts' as soil, seed, and water from nature, and with these man's life was made possible. Man has to pay for these received virtues in the form of agricultural work. This was the basic ideological pillar of Ninomiya's work thought, and the movement started by him was named after this. Ninomiya's thought will be dealt with in some depth in Chapter 6.

7. Gluck, C., Japan's Modern Myths - Ideology in the Late Meiji Period, Princeton University Press, Princeton, 1985.

8. See, for instance, Takahashi Tansui, Shingaku Shüyō Monogatari, Daibunkan Shoten, Ösaka, 1933, a research work on Ishida. For Ninomiya, see Mizumachi Kiyoshi, Ninomiya Sontoku-̄̄ no Dōtoku Keizai Shisō, Meirōsha, Tōkyō, 1937.

9. Ishikawa Ken, Sekimon Shingakushi no Kenkyü, Iwanami Shoten, Tōkyō, 1938. This large volume by Ishikawa, a specialist in the history of education in pre-modern and modern Japan, includes intellectual analysis of Ishida's thought and its ideological origins, detailed historiographical research on the diffusion of his thought, and its impact on society from the perspective of popular education in Tokugawa Japan. Ishikawa's another work, Shingaku Kyōka no Honshitsu narabi ni Hattatsu, Seishisha, Tökyö, 1982 (first published in 1931 by Shōkasha, Tokyo) consists mainly of statistical analysis of the spread of Ishida's thought in the second half of the eighteenth and the early nineteenth centuries. Shibata Minoru (ed.), Ishida Baigan Zenshü, Sekimon Shingakukai, Tökyō, 1955. Abbreviated to ' $I B Z$ ' hereafter. Shibata is a descendant of a Sekimon Shingaku disciple, Shibata Kyuō, and was the head of 
Meirinsha, a leading Shingaku academic centre which still exists in Kyōto. His works include Baigan to sono Monry $\bar{u}$, Mineruva Shobō, Kyōto, 1977, and Shingaku (Nihon Rekishi Shinsho), Shibundō, Tōkyō, 1967, a concise introduction to Ishida and the Sekimon Shingaku. Works by both scholars eclipsed, though not completely, the earlier image of Ishida and his thought. Their works provide solid empirical foundations, but fall short of generating an intellectual debate on the nature and significance of Ishida's thought on work.

10. Bellah, R.N., Tokugawa Religion, The Free Press, New York, 1985 (first published in 1957), chapter 6. Bellah's argument will be discussed in some detail in Chapter 4 below.

11. See Takenaka Yasukazu, Sekimon Shingaku no Keizai Shisō, Mineruva Shobō, Kyōto, 1962.

12. Sasai Shintarō (ed.), Ninomiya Sontoku Zensh̄̄, Ninomiya Sontoku Igyō Senyōkai, Shizuoka, 1927-1932. Abbreviated to ' $N S Z$ ' hereafter.

13. Sasai Shintarō, Ninomiya Sontokuden, Nihon Hyōronsha, Tōkyō, 1935.

14. Naramoto Tatsuya, Ninomiya Sontoku, Iwanami Shoten, Tōkyō, 1959.

15. Ishikawa, Sekimon Shingakushi. Sakasai Takahito, 'Sekimon Shingaku ni okeru Jissen Tetsugaku no Tenkai - Ishida Baigan to Teshima Toan', Rikkyō Keizaigaku Kenkȳ̄, 34-3 (December, 1980). Yasumaru, Nihon no Kindaika to Minshu Shisō.

16. Nakai Nobuhiko, 'Kaidai', Nakai Nobuhiko and Naramoto Tatsuya (eds.), Iwanami Nihon Shisō Taikei, vol. 52: Ninomiya Sontoku, Ōhara Yügaku, Iwanami Shoten, Tōkyō, 1973, p. 483.

17. Harootunian, H.D., Things Seen and Unseen: Discourse and Ideology in Tokugawa Nativism, University of Chicago Press, 
Chicago, 1988.

18. Najita, T., Visions of Virtue in Tokugawa Japan, University of Chicago Press, Chicago, 1987.

19. The scope and method of minshüshi study, and the achievements of the scholars involved in the subject are concisely presented in C. Gluck, 'The People in History: Recent Trends in Japanese Historiography', Journal of Asian Studies, 38-4 (November, 1978). A select bibliography is also attached.

20. See Walthall, A. (ed. \& tr.), Peasant Uprisings in Japan, University of Chicago Press, Chicago, 1991, for examples of the sources.

\section{Chapter 2}

1. Hayami Akira and Miyamoto Matao (eds.), Iwanami Nihon Keizaishi, vol.1 (Keizai Shakai no Seiritsu), Iwanami Shoten, Tōkyō, 1988. Shinbo Hiroshi and Saitō Osamu (eds.), Iwanami Nihon Keizaishi, vol. 2 (Kindai Seichō no Taidō), Iwanami Shoten, Tōkyō, 1989.

2. See works by Hazama Hiroshi, a leading scholar on labour history of modern Japan, including his Nihon Rōmu Kanrishi Kenkyū, Ochanomizu Shobō, Tōkȳ̄, 1978 (first published in 1964), and Rōshi Kyōchō no Teiryū, Waseda Daigaku Shuppankai, Tōkyō, 1978, portions of which have been translated as "Japanese Labor-Management Relations and Uno Riemon", Journal of Japanese Studies, 5-1 (Winter, 1979). Reliable English sources on modern Japanese labour history include A. Gordon, The Evolution of Labor Relations in Japan: Heavy Industry, 1853-1955, Council on East Asian Studies/Harvard University Press, Cambridge (Massachusetts), 1985, and S. Garon, The State and Labor in Modern Japan, University of California Press, Berkeley, 1987. 
3. Hiraishi Naoaki, 'Kinsei Nihon no "Shokugyō"kan', Tōkyō Daigaku Shakai Kagaku Kenkyūsho (ed.), Gendai Nihon Shakai, vol. 4 (Rekishiteki Zentei), Tōkyō Daigaku Shuppankai, Tōkyō, 1991. Harootunian, Things Seen and Unseen.

4. Applebaum, H. (ed.), Work in Non-market and Transitional Societies, SUNY (State University of New York) Press, Buffalo, 1984 , introduction.

5. Joyce (ed.), The Historical Meanings of Work, introduction.

6. Hepburn, J.C., Waei Gorin Shūsei, American Presbyterian Mission Press, Shanghai, 1867, pp. 95, 400 (J-E), 57, 131 (E-J). In a "Pocket Dictionary" compiled by Hori Tatsunoskay and published in 1862, 'work' was translated as shigoto, as was the term 'labour'. The Japanese term saikumonogyo, which literally means handicraft work, was also used as a translation of 'work'. Hori Tatsunoskay (Tatsunosuke), 'A Pocket Dictionary of the English and Japanese Language', Yedo (Tōkyō), 1862. Reprinted in Sugimoto Tsutomu (ed.), Edojidai Hon'yaku Nihongo Jiten, Waseda Daigaku Shuppanbu, Tōkyō, 1981, pp. 835, 961.

7. Tsuchiya Tadao, et. al. (eds.), Nippo Jisho (JapanesePortuguese Dictionary - translated into contemporary Japanese language from Vocabvlario Da Lingoa De Iapam: com a declaracao em Portugues of 1603), Iwanami Shoten, Tōkyō, 1980, p. 583.

8. Kindaichi Kyōsuke, et. al. (eds.), Nihon Kokugo Daijiten, Shōgakukan, Tōkyō, 1972-1976, vol. 11, p. 376. Hiraishi, 'Kinsei Nihon no "Shokugyö"kan', p. 47.

9. Hiraishi, 'Kinsei Nihon no "Shokugyō"kan', pp. 47-8.

10. Kindaichi, et. al. (eds.), Nihon Kokugo Daijiten, vol. 15, p. 357.

11. Ibid., vol. 11 , p. 376 . Ibid., vol. 15 , p. 357. 
12. Niimura Izuru (ed.), Kōjien (third and revised edition), Iwanami Shoten, Tōkyō, 1983, p. 992.

13. Kindaichi, et. al. (eds.), Nihon Kokugo Daijiten, vol. 10, p. 672 (shoku). In the Muromachi era, 悈 read as shiki referred to revenue rights assumed usually by shugo and other administrators of similar ranks. In the Edo period, however, the term referred to one's occupation in general terms. Ibid., vol. 9, p. 416 (shiki). Ibid., vol. 17, p. 551 (bun).

14. Kaibara Gakken's 'Supplement' to Miyazaki Yasusada's Nōgyō Zensho, published in 1696. Nōgyō Zensho was edited by Tsuchiya Takao and published in 1936 from Iwanami Shoten, Tōkyō. The quoted passage is from p. 348 of this Iwanami edition.

15. For more details regarding the use of the word shokubun, see Hiraishi, 'Kinsei Nihon no "Shokugyo"kan', pp. 48-50.

16. Muro Kyūsō, Nō kō shō no Koto in 'Fubōshō', Takimoto Seiichi (ed.), Nihon Keizai Taiten, vol. 6, Keimeisha, Tōkyō, 1928, pp. 70-71.

17. Harootunian, Things Seen and Unseen, p. 249.

18. Hiraishi, 'Kinsei Nihon no "Shokugyō"kan', pp. 50-51.

19. Bitō Masahide, 'Tokugawa Jidai no Shakai to Seiji Shisō no Tokushitu', Shisō, 685 (July, 1981). Also, Nihonshi Kenkȳu, 324 (August, 1989).

20. Asao Naohiro, 'The Sixteenth-Century Unification', J.W. Hall, et. al. (eds.), The Cambridge History of Japan, vol. 4, Cambridge University Press, Cambridge, 1991, p. 52.

21. Bitō, 'Tokugawa Jidai no Shakai', p. 5.

22. Ogyū Sorai, 'Taiheisaku', Nishida Taichirō, Maruyama Masao, et. al. (eds.), Iwanami Nihon Shisō Taikei, vol. 36: Ogyū Sorai, Iwanami Shoten, Tōkyō, 1973, p. 453. 
23. Bitō, 'Tokugawa Jidai no Shakai', pp. 5-6.

24. Ibid., pp. 5, 10-12. Iwashiro Takuji's research on Ōta village in the Province of Kawachi reveals the picture of peasants' involvement in corvee, and the ingredient of buyaku and fusei in some detail. Iwashiro Takuji, 'Kinsei Sonraku to Murayaku Rōdō', Nihonshi Kenkyū, 324 (August, 1989).

25. Asao Naohiro, 'Kōgi to Bakuhan Ryōshusei', Rekishigaku Kenkyūkai and Nihonshi Kenkyūkai (eds.), Kōza Nihon Rekishi, vol. 5 (Kinsei 1), Tōkyō Daigaku Shuppankai, Tōkyō, 1985, p. 49.

26. In addition to these arguments and intellectual debates on the concept of yaku by Bitō and Asao, Takagi Shōsaku's research on the legal aspect of the economic system of villages in 1976 suggests yaku's 'multi-tasked' nature. Takagi Shōsaku, 'Bakuhan Shoki no Mibun to Kuniyaku', Rekishigaku Kenkyu, special edition (November, 1976).

27. Mizumoto Kunihiko, 'Kōgi to Mura, Hyakushō', Kōza Nihon Rekishi, vol. 5 (Kinsei 1), pp. 136-45.

28. Ötō Osamu, 'Mibun to Ie', Fukaya Katsumi and Matsumoto Shirō (eds.), Kōza Nihon Kinseishi, vol. 3, Yühikaku, Tōkyō, 1980, pp. 148-69. Ōtō specialises in economic historiographical research on Tokugawa villages, and also conducted studies on Ninomiya, which will be examined in Chapter 7 below. In this particular study, Ōto simply intended to reveal the evolutionary process of the small peasant household towards becoming an independent production unit. It is not intended to be an investigation into the nature of the yaku concept itself.

29. Nakane Chie, Kinship and Economic Organisation in Rural Japan, London School of Economics/Athlone Press, London, 1967, chapter 1 .

30. Saito Osamu, 'Marriage, Family Labour and the Stem- 
family Household: Traditional Japan in a Comparative Perspective', R. Wall and Saitō Osamu (eds.), The Economic and Social Aspects of the Family Life-cycle: Europe and Japan, Traditional and Modern, Cambridge University Press, Cambridge, forthcoming, pp. 11-33.

31. Aoki Kazuo, et. al. (eds.), Nihonshi Daijiten, Heibonsha, Tōkyō, 1992-1994, vol. 2, pp. 125-26.

32. Kindaichi, et. al. (eds.), Nihon Kokugo Daijiten, vol. 4, p. 400 .

33. Ibid., p. 400.

34. Hiraishi, 'Kinsei Nihon no "Shokugyō"kan', pp. 41, 54.

35. IBZ, vol. 1 , p. 61 .

36. Tamura (Jinzaemon) Yoshishige, 'Yoshishige Ikun', Iinuma Jiro, et. al. (eds.), Nihon Nōsho Zenshū, vol. 21, Nōsangyoson Bunka Kyōkai, Tōkyō, 1981, p. 224. Yoshishige Ikun is one of the examples of the family precepts of peasant households in the Tokugawa and the early Meiji periods which includes farming methods, family regulations and admonitions. Tamura is also the author of Nögyo Jie, which deals extensively with agricultural technology and its management. Ibid., pp. 3-96.

37. Fukaya Katsumi, Hyakushō Naritachi, Hanawa Shobō, Tōkyō, 1993, pp. 118-19.

38. R.W. Malcolmson, 'Ways of Getting a Living in Eighteenth-Century England', and M. Berg, 'Women's Work, Mechanization and the Early Phases of Industrialization in England'. Articles are in Pahl (ed.), On Work. Also, see Pahl, 'Introduction: Work in Context', Ibid., esp. pp. 10-12.

39. Fukaya, Hyakushō Naritachi, pp. 159-84.

40. Ibid., pp. 166-67.

41. Ibid., p. 164. 
42. Ibid., pp. 173-74.

43. Ibid., p. 178.

44. Smith, T.C., Native Sources of Japanese Industrialization, 1750-1920, University of California Press, Berkeley, 1988, chapter 1 .

45. Saitō Osamu, Puroto Kōgyōka no Jidai, Nihon Hyōronsha, Tōkyō, 1985, p. 173.

46. Ibid., Chapter 2.

47. Ibid.

48. Applebaum (ed.), Work in Non-market, p. 4.

49. Ibid., pp. 1-3. In some non-market societies, however, a term representing 'work' exists, if not a rigid concept of it; in traditional Tikopia society, for instance, the term fekau indicated 'expenditure of energy for accomplishment of ends, at some sacrifice of comfort or leisure'. R. Firth, 'Work and Value: Reflections on Ideas of Karl Marx', S. Wallman (ed.), Social Anthropology of Work, Academic Press, London, 1979, pp. 191-92. Exchange of goods between non-relatives with a certain 'exchange value' based on the amount of labour investment both in terms of time and skill also existed in Tikopia. Ibid., pp. 193-95. Applebaum's assertion thus needs to be qualified.

50. Saitō Osamu, Puroto Kōgyōka, pp.183-84.

51. See, for instance, Fukuda Ajio, Kan $\overline{-}$-sei to shite no Mura Shakai: Rōdō to Jōhō no Minzokugaku, Seikyusha, Tōkyō, 1990, pp. 36-50.

52. Applebaum (ed.), Work in Non-market, pp. 1-2.

53. Vlastos, S., Peasant Protests and Uprisings in Tokugawa Japan, University of California Press, Berkeley, 1986, especially, conclusion. 


\section{PART II ISHIDA BAIGAN}

\section{Introduction to Part II}

1. For customs and trading practices in Tokugawa merchant households, see Miyamoto Mataji's studies. Miyamoto Mataji, Kinsei Shōnin Ishiki no Kenkyū: Kakun Oyobi Tensoku to Nihon Shōnindō, Yūhikaku, Tōkyō, 1942. Miyamoto Mataji, Kamigata no Kenkȳu, Seibundō, Ōsaka, 1977.

2. A concise summary of the development of shingaku (learning of the mind and heart) in East Asia can be found in J. Anderson Sawada, Confucian Values and Popular Zen: Sekimon Shingaku in the Eighteenth Century, University of Hawaii Press, Honolulu, 1993. She argues that the "learning of the mind" originated in the Neo-Confucian revival of Sung China (960-1280). It reached Japan in the sixteenth and seventeenth centuries, after successive modification efforts by Chinese and Korean Neo-Confucians. Such Japanese Neo-Confucians as Kaibara Ekken (1630-1714) and Nakae Toju (1608-1648) were the early recipients of the idea of 'learning' in Tokugawa Japan. By the middle of the Tokugawa period, shingaku came to be identified with the teachings of Nakae Toju and his disciple, Kumazawa Banzan (1619-1691). Anderson Sawada, op. cit., pp. 1-3.

While the shingaku started by Ishida Baigan - named 'Sekimon Shingaku' - emphasised such issues as "purifying the self", "learning of the heart", and "cultivation of the self", these were commonly advocated also in the preceeding shingaku thought and movement of Toju and Ekken. However, Ishida's Sekimon Shingaku differed from other schools in terms of its emphasis on the 'method' of cultivation; to cultivate the heart, it emphasised the pursuit of everyday work, not a particular, sublime method such 
as investigation and meditation. Hereafter, 'Sekimon Shingaku' will be abbreviated to 'Shingaku' to differentiate it from other shingaku schools.

\section{Chapter 3}

1. Shibata, Baigan to sono Monryü, pp. 13-15.

2. $I B Z$, vol. 1, p. 117.

3. Gojō Gorin no Michi (五常五輪之道) = five moral constants and five social relationships; Gojō no Michi are, benevolence, righteousness, courtesy, wisdom, and faithfulness: Gorin no Michi are the duties between sovereign and minister, father and son, husband and wife, elder brother and younger, and those pertaining to social intercourse between friends: from Doctrine of the Mean chapter 20-8, Clarendon Press, Oxford, 1893. Translated by James Legge.

4. $I B Z$, vol.1, p.116.

5. Ibid., p.117.

6. See Nakamura Hajime, 'Suzuki Shōsan, 1579-1655, and the Spirit of Capitalism in Japanese Buddhism', Monumenta Nipponica, 22, 1-2 (1967). Also, Bellah, Tokugawa Religion, pp. 78-79.

7. The T'ai-chou branch of the Wang Yang-ming school of Neo-Confucianism in late Ming China (1368-1644) advocated that the masses were also entitled to attain 'sagehood'. In their view, self-cultivation could be achieved through morally responsible activity, including work. Judith A. Berling, 'Religion and Popular Culture: The Management of Moral Capital in The Romance of the Three Teachings', D. Johnson et. al. (eds.), Popular Culture in Late Imperial China, University of California Press, Berkeley, 1985, p. 217. 
8. IBZ, vol. 2, p.621.

9. Ishikawa Ken has compiled a variety of theses concerning the ideological origins of Shingaku from existing scholarship. See Ishikawa, Sekimon Shingakushi, pp. 38-57. Although he briefly discusses conflicting views about 'origins', he seems to have refrained from stating any conclusive thesis himself. Recently, Anderson Sawada attempted to discuss the issue, only to conclude, perhaps following Ishikawa, that the 'Shingaku openness to different religious elements was shaped by a fundamental premise: human beings can reach moral perfection by experiencing the true nature of the mind. Religious doctrines and practices function in the Shingaku system according to their compatibility with this credo'. Anderson Sawada, Confucian Values, p. 4; Ishikawa, Sekimon Shingakushi, p. 54. Although one can assert that Shingaku had never been 'syncretic', in which religious situation conflicting and incoherent ideas are brought together (Anderson Sawada, op. cit., p.4), it seems that the only possible conclusion is that Shingaku duly embraced a 'synthetic' element in its thought, despite its stronger inclination toward Confucianism.

10. Uekawa Kisui, 'Kyōchō Gorakusha Shingaku Shōden no Zu', Shibata Minoru (ed.), Iwanami Nihon Shisō Taikei, vol. 42:

Sekimon Shingaku, Iwanami Shoten, Tökyō, 1971, pp. 202-203. Ishikawa, Sekimon Shingakushi, p. 39. Shibata, Baigan to sono Monry $\vec{u}$, pp. 145-46.

11. Chu Hsi was a preeminent Chinese Neo-Confucian, who synthesised and completed the early Sung philosophers' re-assessment works on Confucianism in China. He strengthened the theoretical aspect of Confucianism mainly through the formulation of a metaphysics encompassing both the universe and man. Maruyama Masao, Nihon Seiji Shisōshi Kenkȳu, Tōkyō 
Daigaku Shuppankai, Tōkyō, 1952. A classic work by Fung in 1942 presents a concise discussion of Chu Hsi metaphysics. Fung, Yu-lan, 'The Philosophy of Chu Hsi', Harvard Journal of Asiatic Studies, 7 (1942-1943), pp. 1-51. Translated by Derke Bodde. For details of Neo-Confucian terminologies, see Ch'en Ch'un's The Pei-hsi tzu-i, translated into English in Wing-tsit Chan, Neo-Confucian Terms Explained, Columbia University Press, New York, 1986. Other sources which discuss this issue in some detail include Maruyama Masao, Nihon Seiji Shisōshi Kenkyū. Later scholarly works tend to be more focused on individual thinkers who belonged to particular branches and schools of the Neo-Confucian thought system, and not many 'general' accounts can be found. However, a good overview can be found in M.E. Tucker, Moral and Spiritual Cultivation in Japanese Neo-Confucianism: The Life and Thought of Kaibara Ekken (1630-1714), SUNY (State University of New York) Press, Buffalo, New York, 1990.

12. Maruyama, Nihon Seiji Shisōshi Kenkyū, pp. 23-5.

13. Tucker, Moral and Spiritual Cultivation, pp. 60-1.

14. See de Bary, Wm. T., Neo-Confucian Orthodoxy and the Learning of the Mind-and-Heart, Columbia University Press, New York, 1981, esp., Part II (pp. 67-185).

15. IBZ, vol.1, p. 38 .

16. Ibid., p. 473.

17. Ibid., pp. 215-16.

18. Watanabe Hiroshi, 'Tokugawa Zenki Jugakushi no Ichi Jōken', Kokka Gakkai Zasshi, 94-1,2 (1981), pp. 67-69.

19. H.D. Harootunian, 'Metzger's Predicament' in the 'Review Symposium: Thomas A. Metzger's Escape from Predicament', Journal of Asian Studies, 34-2 (February, 1980), p. 254. 
20. $I B Z$, vol. 1 , p. 10 .

21. Bellah, Tokugawa Religion, p. 151.

22. de Bary, Neo-Confucian Orthodoxy, pp. 206-209.

23. Shibata Minoru, Shingaku (Nihon Rekishi Shinsho),

Shibundō, Tōkyō, 1967, p. 190. Ishikawa Ken also argued that it was not seiza or $k u f \bar{u}$ which Ishida stressed as primary means of cultivation. It was one's active conduct of thrift and labour.

Ishikawa Ken, Ishida Baigan (Nihon Kyōiku Sentetsu Sōsho), Bunkyō Shoin, Tōkyō, 1943, pp. 24, 30-31.

24. Ishikawa, Sekimon Shingakushi, p. 178.

25. IBZ, vol. 1, pp. 8-9.

26. Ibid., p. 82.

27. Ibid., p. 4.

28. Kojima Yasunori, 'Kinsei Nihon Shisōshi ni okeru 'Kokoro' to 'Katachi", Minamoto Ryōen (ed.), Kata to Nihon Bunka, Sōbunsha, Tōkyō, 1992, pp. 98-116.

29. Ibid., pp. 101-105.

30. Najita, Visions of Virtue in Tokugawa Japan, p. 44.

31. Yu, Ying-shi, Chūgoku Kinsei no Shükyō Rinri to Shönin Seishin, Heibonsha, Tōkyō, 1991, pp. 158-66. This account was translated from Yu, Ying-shi, Zhong-guo jin-shi zong-jiao lun-li yu shang-ren jing-shen, Taipei, 1987, by Mori Noriko.

32. Minamoto Ryōen, Kinsei Shoki Jitsugaku Shisō no Kenky $\bar{u}$, Sōbunsha, Tōkyō, 1980, pp. 81-91.

33. Ibid., pp. 79-81. Also, Hiraishi, 'Kinsei Nihon no "Shokugyō" kan', pp. 40-1.

34. Pak, T., 'Richō Koki ni okeru Seiji Shisō no Tenkai', Kokka Gakkai Zasshi, 88-11, 12 (1975), pp. 629-91.

35. Minamoto, Kinsei Shoki Jitsugaku, pp. 101.

36. Ibid., pp. 101-102. 
37. de Bary, Wm. T. and I. Bloom (eds.), Principle and

Practicality: Essays in Neo-Confucianism and Practical Learning, Columbia University Press, New York, 1979, p. 25.

38. Ibid., p. 33.

39. A record of numerous examples of trading house bankruptcies can be found, for instance, in the diary of Kawachiya Yoshimasa, a landholder who also ran liquor shops in the Province of Kawachi. Nomura Yutaka and Yui Kitarō (eds.), Kawachiya Yoshimasa Kyūki, Seibundō Shuppan, Ōsaka, 1970 (first published in 1955). Ishida Baigan also lamented the notorious situation of trading house bankruptcies where he found 'seven or eight houses out of ten collapsed'. IBZ, vol. 1, p. 197. It would be risky to assume any statistical reliability in this statement. However, the record of Kawachi, and the 'impression' given by Ishida on the state of things, give an authentic picture of the economic situation the trading houses were facing in the eras of Genroku and Kyoho.

40. Ogyū Sorai, 'Seidan, vol. 2', Nishida Taichirō, Maruyama Masao, et. al. (eds.), Iwanami Nihon Shisō Taikei, vol. 36: Ogȳ̄ Sorai, Iwanami Shoten, Tōkyō, 1973, p. 307.

41. Ibid., pp. 306-45.

42. IBZ, vol. 1, p. 82 .

43. Ibid., p. 76.

44. Ibid., p. 90 .

45. Ibid., p. 82.

46. Ibid., p. 78.

47. Ibid., p. 82 .

48. Ibid., p. 87.

49. $I B Z$, vol. 2, p. 283.

50. IBZ, vol. 1, p. 88 .

51. Ibid., p. 81 . 


\section{Chapter 4}

1. Thompson, P., 'Playing at Being Skilled Men: Factory Culture and Pride in Work Skills among Coventry Car Workers', Social History, 13 (1988), p. 45.

2. More, C., 'Skill and the Survival of Apprenticeship', S. Wood (ed.), The degradation of work?: Skill, De-skilling and the Labour Process, Hutchinson, London, 1982, p. 109.

3. The quoted lines are from M.C. Kennedy's unpublished PhD thesis. Quoted in H. Braverman, Labor and Monopoly Capital: The Degradation of Work in the Twentieth Century, Monthly Review Press, New York, 1974, p. 444.

4. Rule, J.,'The Property of Skill in the Period of Manufacture', Joyce (ed.), The Historical Meanings of Work, p. 104.

5. Marx, K., Capital, vol. 1, Lawrence and Wishart, London, 1983 (L\&W version first published in 1954), chapter 14: Division of Labour and Manufacture. German edition, Das Kapital, was first published in 1867. English edition first published in 1887.

6. Rule, 'The Property of Skill', pp. 104-6.

7. This definition is quoted from 'Glossary of Labour Process Terms' in P. Thompson, The Nature of Work, Macmillan, London, 1989 (first published in 1983), p. xiv.

8. Turner, H.A., Trade Union Growth: Structure and Policy, George Allen and Unwin, London, 1962, pp. 110-14.

9. H.A. Turner was probably the first who noticed the constructed element of skill in 1962, although he did not clearly state it as a 'social construct'. He has subsequently been followed by authors including Phillips and Taylor, 'Sex, Class in the Capitalist Labour Process' - paper presented to Windsor 
conference, 1978, Wood (ed.), Degradation of Work?, Pahl (ed.), On Work, and so on.

10. Thompson, E.P., Customs in Common, Merlin Press, London, 1991, p. 10.

11. For a detailed description of the nature of labour relations and of industrial disputes in modern Japan, see Hazama, 'Japanese Labor-Management Relations and Uno Riemon' (Röshi Kyōchō no Teiryū), Journal of Japanese Studies, 5-1 (Winter, 1979), and S. Garon, The State and Labor in Modern Japan, chapters 1 and 2.

12. One might argue that the Japanese workers' call for the restoration of the 'household-like system' in industrial disputes is almost synonymous with the English workers' call for the 'reinstatement of paternalist regulations'. However, it has to be noted that the chief aims of the disputes by the Japanese workers were the improvement in the treatment of employees (taig $\bar{u}$ no kairyō) which embraces the 'benevolent relationship' between the employer and employees, and the improvement of one's 'respectability' (chii no kōjyō). Smith, Native Sources of Japanese Industrialization, esp. pp. 236-47. It did not aim to preserve a certain 'skill' and the stake of a skill group based on a particular skill. See also Hazama, Nihon Rōmu Kanrishi Kenkyü, pp. 14-121, and A. Gordon, The Evolution of Labor Relations in Japan.

13. 'Skill' is generally translated into jukuren in contemporary Japanese. But the Edo words mentioned in the text stood for technical skill and instrument [waza = Kindaichi, et. al. (eds.), Nihon Kokugo Daijiten, vol. 20, p. 638], one's level of ability in accomplishing tasks [giry $\bar{o}=I$ bid., vol. 6, p. 293], and skilfulness [takumi $=$ Ibid., vol. 12, p. 712].

14. For Ōkura's agricultural treatises, see linuma, et. al. (eds.), 
Nihon Nōsho Zensh̄̄, vols. 14 and 15 .

15. Miyamoto Mataji, Kinsei Shōnin Ishiki no Kenkyū. Najita, Visions of Virtue in Tokugawa Japan.

16. Sekiyama Naotarō, Kinsei Nihon no Jinkō Kōzo, Yoshikawa Kōbunkan, Tōkyō, 1958, pp. 275-307.

17. 'Occupational Structure of Great Britain, Males, 1841-1921' in B.R. Mitchell and P. Deane, Abstract of British Historical Statistics, Cambridge University Press, Cambridge, 1971, p. 60.

18. Schwarz, L.D., 'Income Distribution and Social Structure in London in the Late Eighteenth Century', Economic History Review, 32 (1979), pp. 256-57.

19. Marx, K. and F. Engels, 'The German Ideology' (1845), J. Cohen, E.J. Hobsbawm, et. al. (eds.), Collected Works, 5, Lawrence and Wishart, London, 1976, pp. 65-67. However, E.P. Thompson argues that paternalist control over the whole life of the labourer was being eroded in the first six decades of the eighteenth century. E.P. Thompson, Customs in Common, pp. 35-38.

20. Saitō Osamu, Shōka no Sekai, Uradana no Sekai, Riburo Pooto, Tōkyō, 1987, esp. pp. 38, 101-102, 123, 165-66.

21. Saitō Osamu, 'Jukuren, Kunren, Rōdō Shijō', Kawakita Minoru (ed.), Shiriizu Sekaishi eno Toi, vol. 2: Seikatsu no Gijutsu, Seisan no Gijutsu, Iwanami Shoten, Tokyo, 1990, pp.170-71.

22. IBZ, vol.1, p. 270.

23. Ibid., p. 271.

24. In fact, mutual care and 'concern' in inter-personal contexts tended to be regarded as 'ethical practice'. See, for instance, Takenaka, Sekimon Shingaku no Keizai Shiso, pp. 445-49. Miyamoto Mataji even argues that the admonitions of the family precepts concerning inter-personal care were the 'remains' of 
feudal elements, and dismissed them as 'negative' (shōkyoku teki) elements of the precepts. Miyamoto Mataji, Kinsei Shönin Ishiki no Kenky $\bar{u}$, pp. 73-87. On the other hand, advocacies on such 'individual' skills in commerce as acumen in trading (shösai) and precision in calculation ( $\operatorname{san}^{\prime} y \bar{o}$ ) were regarded as 'positive' elements of the trading house precepts.

25. IBZ, vol. 1, p.74.

26. Kokushi Daijiten Henshū linkai (ed.), Kokushi Daijiten vol. 4, Yoshikawa Kobunkan, Tökyō, 1983, p. 458. As for the term ryō (로), see also Niimura (ed.), Köjien, p. 2,518. See also Matsumura Akira (ed.), Daijirin, Sanseidō, Tōkyō, 1988, p. 658.

27. IBZ, vol.1, pp. 336-37.

28. Minamoto Ryōen and Sakasai Takahito, however, focus on Ishida's advocacy for retainers' subjectivity in their respective studies. See Minamoto Ryōen, 'Ishida Baigan-ron', Imai Atsushi and Furuta Shōkin (eds.), Ishida Baigan no Shisō, Perikansha, Tokyo, 1979, pp. 73-120. Sakasai, 'Sekimon Shingaku ni okeru Jissen Tetsugaku no Tenkai'.

29. IBZ, vol. 1 , pp. 270.

30. Ibid., p. 271. A similar clause can be found in the family precepts of other trading houses of eighteenth-century Kyōto. Such a large trading house as Mitsui had a clause in its precepts which legitimised the expelling of a prospective heir if he were indulgent. Clause 15, 'Mitsui Constitution of 1722'. Quoted in J.G. Roberts, Mitsui: Three Centuries of Japanese Business, Weatherhill, New York, 1973, pp. 501-502 (Appendix A).

31. Weber, M., Purotesutantizumu no Rinri to Shihon Shugi no Seishin, Iwanami Shoten, Tökyō, 1991, pp. 305-17. This is the third revision of Purotesutantizumu no Rinri to Shihon Shugi no Seishin, originally translated by Kajiyama Tsutomu from Die 
protestantische Ethik und Der Geist des Kapitalismus, Gesammelte Aufsatze zur Religionssoziologie, Bd. 1, 1920, SS. 17-206, and published by Yūhikaku in 1938. This account has been revised and translated by Ōtsuka Hisao.

32. Weber's discussion of the role of religion in Japan remained more or less marginal in his study of the sociology of religion, due largely to the limited availability of materials in his time. He nonetheless referred to the issue, stating that religion remained 'rigidly ceremonial and directed towards purely inner-worldly concerns'. See M. Weber, 'The Religions of Asia' in W.G. Runciman (ed.), Weber: Selections in translation, Cambridge University Press, Cambridge, 1978, pp. 196-97. The article was translated from Gesammelte Aufsatze zur Religionssoziologie, 2nd edn, Tubingen, 1923, II, s. 363-78. The original edition was published in 1917.

33. Bellah, Tokugawa Religion, pp. 5, 14.

34. Ibid., p. 5, 15.

35. Ibid., p. 165.

36. Ibid., pp. 165, 185, 187, 194.

37. Ibid., pp. 185, 187.

38. Ibid., pp. 187-8.

39. Smith, T.C., The Agrarian Origins of Modern Japan, Stanford University Press, Stanford, 1959.

40. Aoki Masahiko, Information, Incentives, and Bargaining in the Japanese Economy, Cambridge University Press, Cambridge (printed in the U.S.), 1988, esp. chapter 2 and conclusion.

41. Bellah, Tokugawa Religion, p.165. 


\section{Chapter 5}

1. Ishikawa, Sekimon Shingakushi. Ishikawa, Shingaku Kyöka no Honshitsu narabi ni Hattatsu.

2. Shibata, Baigan to Sono Monry $\bar{u}$.

3. Miyamoto Mataji, Kinsei Shōnin Ishiki no Kenkyū. Miyamoto Mataji, Kamigata no Kenkyū.

4. Robertson, J., 'Rooting the Pine: Shingaku Methods of Organization', Monumenta Nipponica, 34-3 (Autumn, 1979). Anderson Sawada, Confucian Values and Popular Zen.

5. Shibata, Baigan to sono Monryū, p. 167.

6. Ibid., pp. 170-71.

7. Ishikawa, Sekimon Shingakushi, p. 272.

8. Ibid., p. 272.

9. Shibata, Baigan to Sono Monryū, p. 178.

10. Ishikawa, Sekimon Shingakushi, pp. 312- 433.

11. Ibid., pp. 399-400.

12. Ishikawa, Shingaku Kyōka no Honshitsu, p. 192.

13. Ishikawa, Sekimon Shingakushi, pp. 739-82, 978-87.

14. Ibid., p. 555.

15. Ishikawa, Shingaku Kyōka no Honshitsu, pp. 211-24.

16. Teshima Toan, 'Jijo Nemuri Samashi', Meirinsha (ed.), Teshima Toan Zensh̄̄, Meirinsha, Kyōto, 1931, pp. 47-67.

17. Ichimura Yuichi, 'Shingaku Dôwa to Komyunikeishon', Bitō Masahide Sensei Kanreki Kinenkai (ed.), Nihon Kinseishi Ronsō, vol. 2, Yoshikawa Kōbunkan, Tōkyō, 1984.

18. Teshima Toan, 'Zenkun', Teshima Toan Zensh $\vec{u}$, pp. 69-93.

19. Teshima Toan, 'Kaiyū Taishi', Ibid., p. 97.

20. Ibid., p. 98.

21. Ibid., p. 98.

22. Anderson Sawada, Confucian Values and Popular Zen. 
Anderson Sawada argues that Shingaku provided the commoners with methods of cultivating the 'original mind' by themselves. Neo-Confucian texts failed, in Sawada's words, to prescribe a feasible method of cultivation for busy merchants, artisans and farmers. In contrast, a peculiar element of Shingaku teaching lies in its sensitivity to the 'context of everyday life'; it amalgamated the Neo-Confucian concept of cultivation and "casualised" Zen practices for attainment, and provided the commoners with practically employable means to "quest the mind". Ibid., pp. 4, 8, $165,166$.

Anderson Sawada was right in pointing out the importance of the concept of cultivation in Shingaku teaching. However, Ishida argued in Tohi-Mondo that cultivation could be achieved through the daily activities of the populace, that is, through work, not through 'group study' or 'contemplation'. Anderson Sawada, in contrast, argues that Shingaku methods of cultivation lie in such 'extraordinary' activities as study and meditation. Ibid., pp. 91-109. Indeed, Sawada describes the means of cultivation and educational programmes developed in Shingaku teaching in the post-Baigan era, but most of these were alien to the pursuit of daily activities. This may well have been the propensity in Shingaku teaching in the post-Toan era, while it was certainly not the case in Baigan's time, nor, probably, in the first half of the Toan era. After all, Shingaku's alienation from secular means was a major factor behind the loss of pupils to more practical, production-oriented movements, such as the Hōtoku movement in the nineteenth century. (see note 24 below).

23. Nakazawa Dōni, 'Dōni-̄̄ Dōwa', Iwanami Nihon Shisōo Taikei, vol. 42: Sekimon Shingaku, pp. 207-32 (esp. pp. 210-1). This view of the later Shingaku movement is also shared by 
Ishikawa in his Sekimon Shingakushi, pp. $492-584$ (esp., p. 532), and by Tsuda Hideo in his 'Kyōiku no Fukyū to Shingaku', Asao Naohiro, Ishii Susumu, et. al. (eds.), Iwanami Kōza Nihon Rekishi, vol. 12 (Kinsei 4), Iwanami Shoten, Tōkyō, 1976, p. 164.

24. Kobayashi Heibei, a village headman of Kamado Shinden village in the Province of Suruga, was an active member of the Shingaku movement in the Bunsei era (1818-29). He 'transferred' himself from Shingaku to Hōtoku after 1837 when Ninomiya Sontoku came to inspect the village. He became a leading figure as well as a chief financial provider of the shiho implementation in the village. Niki Yoshikazu, 'Odawarahan Kamado Shinden Mura no Hōtoku Shihō ni tsuite', Rikkyō Keizai Kenkyū, 45-3 (January, 1992), pp. 123-62.

Similar transitions occurred in other villages in the Kantō region. The villages of Yatabe and Oda in the Province of Hitachi, for instance, abandoned the Shingaku academic centres established in the villages and started to adapt the shiho programme in the Tenpö era (1830-44). For Yatabe's Shingaku, see Ōtō Osamu, 'Kantō Nōson no Kōhai to Sontoku Shihō', Shiryōkan Kenkȳu Kiyō, 14 (supplement volume; September, 1982), pp. 131-66.

25. Miyamoto Mataji, Kinsei Shōnin Ishiki no Kenkyū, p. 154.

26. Ibid., p. 156.

27. Ibid.

28. Articles extracted from the 'Precepts of Household Matters in Ōmiya Jinbei of Kyōto' (Kyōto Ōmiya Jinbei Kaji Kyōkun)'. 'Jinbei of Kyōto Ōmiya' was Saitō Masakado, an Ishida disciple. The original of Saitō's precepts has been kept by Professor Miyamoto Matao of Ōsaka University, son of Mataji. The unabridged articles of Saitō's precepts are also available in Takenaka, Sekimon Shingaku no Keizai Shisō, pp. 446-50. 
29. Sugiura Munenaka, the 'Rule of the Household Work' (Kagyō no Okite), quoted in Takenaka Yasukazu, Nihonteki Keiei no Genryū, Mineruva Shobō, Kyōto, 1977, pp. 150-51.

30. Ibid., pp. 151-55.

31. Ibid., pp. 155-57.

32. Miyamoto Mataji, Kinsei Shōnin Ishiki no Kenkya, pp. 244-46.

33. Ibid., p. 243.

34. Ibid., p. 148.

35. Ibid., p. 164.

36. Miyamoto Mataji, Kamigata no Kenkyū, pp. 221-22. 


\section{PART III NINOMIYA SONTOKU}

\section{Introduction to Part III}

1. Morita Shirō, Ninomiya Sontoku (Asahi Sensho), Asahi Shinbunsha, Tōkyō, 1989 (first published in 1975), pp. 4-9. Newly established branch families needed their own paddies to support their own households. But the land areas allocated to - or newly developed for - these households tended not to be the most desirable ones. Due largely to the shortage of land areas, new development was often confined to sites near the river, or which were less convenient for water allocation. Branch families tended to be vulnerable to natural calamities for this reason. See Ōtsuka Eiji, 'Kinsei Kōki Kita-Kantō ni okeru Shōnō Saiken to Hōtoku Kinyū no Tokushitsu', Nihonshi Kenkȳ̄, 263 (July, 1984), pp. 32-33.

2. Sasai Shintarō, 'Kaidai', NSZ, vol. 1, p. 1.

\section{Chapter 6}

1. NSZ, vol. 1, p. 274. The same diagram can be found in Ibid., pp. 302, 319.

2. Ibid., p. 277. The same diagrams in Ibid., pp. 304, 322.

3. Saitō Takayuki, 'Ninomiya Sensei Goroku vol. 2, No.127', $N S Z$, vol. 36, p. 378. Ninomiya's words of a similar tenor can be found in numerous places; not only in his Kinmōroku and other philosophical accounts but in letters and correspondence with villagers and proprietors during village rehabilitation.

4. NSZ, vol.1, p.146. Similar diagram was employed in Ninomiya's Kinmōroku. Ibid., p. 21.

5. Ibid., p.20. A prototype of this diagram can be found in Ibid., pp. 147-48. 
6. Eight hours is the standard length of work time per day in present-day industrial society, but it does not seem to have been common in many pre-industrial, agrarian work settings. Even so, Ninomiya argues that eight hours was still 'inadequate' for a preson to be called a 'diligent workman'. Ibid., p. 21 .

7. Smith, Native Sources of Japanese Industrialization, chapter 9. Smith presents a number of examples which illustrate the 'time-awareness' of Tokugawa peasants and their productive use of time. From the viewpoint of socio-economic history, Ninomiya's diagram may be seen as a mark of the prevalence of the notion of time even in the economically backward areas of northern Kantō.

8. NSZ, vol.1, p. 35. Also, Ibid., p. 544.

9. Fukuzumi Masae, 'Ninomiya-̄̄ Yawa vol. 5 , No. 227 ', $N S Z$ vol. 36, pp. 820-1.

10. 'Ninomiya-Ō Yawa vol. 4, No. 166', Ibid., p. 783.

11. NSZ, vol.1, p. 7.

12. Ibid., p. 13. The same diagram in Ibid., p. 68.

13. Ibid., p. 338.

14. Ibid., p. 16.

15. Ibid., p. 38.

16. Fukuzumi, 'Ninomiya-O Yawa: A Sequel, No.1', NSZ, vol. 36, p. 831.

17. Maruyama, Nihon Seiji Shisōshi Kenkȳu, pp. 308-9.

Ninomiya consistently spoke of Jindo as 'intentional effort' or the 'initiative' of human beings. [cf. Fukuzumi, 'Ninomiya-O Yawa', $N S Z$, vol. 36, pp. 680, 831] Maruyama was perhaps the first to clarify this element of Ninomiya's thought. It should however be noted that Ninomiya spoke of man's initiative in industry and planning as a triggering mechanism for the maximum activation of 
the potential of nature, not as an act to arbitrate nature. In this respect, Naramoto Tatsuya's assessment of Ninomiya's conception of the two Ways in later years could be seen as more accurate than Maruyama's view. Naramoto Tatsuya, 'Ninomiya Sontoku: Sansai Hōtoku Kinmōroku wo chushin toshite', Shisò, 548 (February, 1970), p. 83.

18. Saitō Takayuki, 'Ninomiya Sensei Goroku vol. 2, No. 134', $N S Z$, vol. 36, p. 380 . Similar discourse is to be found in Fukuzumi, 'Ninomiya-Ō Yawa vol. 1, No. 3', Ibid., p. 679.

19. NSZ, vol. 1, p. 553.

20. Ibid., p. 31.

21. Fukuzumi, 'Ninomiya-O Yawa: A Sequel, No. 24', NSZ, vol. 36, p. 841 .

22. Fukuzumi, 'Ninomiya-Ō Yawa vol. 2, No. 59', Ibid., p. 718. 23. NSZ, vol. 1, p. 891.

24. Ibid., p. 891.

\section{Chapter 7}

1. The shihō programmes which Ninomiya devised and implemented can be classified into two categories: 1) The shiho practised in the Hattori family of Odawara, Shimodate and Karasuyama in northern Kantō may be termed a 'financial shihō programme' which chiefly consisted of the calculation of a family income/expenditure and the proposal for effective investment of capital. 2) The shihō programmes practised in Sakuramachi, Yatabe and Motegi, and the domain of Soma, on the other hand, were much more comprehensive economic rehabilitation programmes. As we shall see in this chapter, the comprehensive version of the shihō programme consisted of all spheres of economic activity, including financial plans, land reclamation and 
infrastructure development, and labour organisation. The financial shiho was primarily concerned with the control and effective use of a limited amount of capital, while the comprehensive version included radical economic plans to increase financial capability through increased production. Some large individual households also employed this type of the shiho programme. There were no less than twenty villages and domains which received direct instructions from Ninomiya in their implementation. In several domains in such provinces as Suruga, Tōtōmi, and Mikawa, the programme was conducted by his pupils.

The implementation of the shiho programme was usually carried out by a group of leaders consisting of Ninomiya himself, a few village headmen from the locality, and, in the case of Sakuramachi, personnel from the domain of Odawara. Ninomiya was given a mandate to conduct the rehabilitation programme, but it was usually carried out on an order from the head of the domain. Sasai Shintarō later called this 'gyōsei-shiki' or 'an administration-based programme'. In the post-Ninomiya era (after his death in 1856), on the other hand, the shiho programmes and the entire Hōtoku movement were carried out by partnership groups; these may be termed, after Sasai, 'kessha-shiki' or 'co-operative-based programme'. The latter formed a group closely related to a co-operative, which was initiated by a few leading figures in a region and formed by local sympathisers willing to contribute to the economic good of the locality. Such a group was usually called Hötokusha ('Society for the repayment of virtue') or 'Gohō Rench $\bar{u}$ ' ('Group of people working for repayment').

Researchers on Ninomiya tend to assume that the term 'shihō' is a proper noun used only for the action taken for village 
rehabilitation. The word 'shihō' was used, however, in more general terms to mean 'device', 'method', or 'means' of dealing with one's difficulties. The use of the word is illustrated in Maeda Isamu (ed.), Edogo no Jiten (Kōdansha Gakujutsu Bunko), Kōdansha, Tōkyō, 1991 (first published in 1979), p. 988. It was not until the second half of the eighteenth century when the villages in the northern Kantō area suffered from severe production decline, and domains began to take initiatives to restore the villages, that the term 'shih $\overrightarrow{0}$ began to appear as a word indicating a village rehabilitation programme. The programme initiated by the head of the domain was called ryōshu shihō. Ninomiya's programme was usually called Sontoku shiho or 'the shihō programme of Ninomiya Sontoku'.

2. Shinbo and Saitō Osamu (eds.), Iwanami Nihon Keizaishi vol. 2.

3. Sekiyama, Kinsei Nihon no Jinkō Kōzō, pp. 137-41.

4. Akimoto Hiroya's study on the Chōshū economy illustrates the development of these elements of Tokugawa agriculture. See Akimoto, Zen Kōgyōka Jidai no Keizai, Mineruva Shobō, Kyōto, 1987, pp. 34, 42-44.

5. Double cropping was practised in 60 to 70 per cent of the entire arable land area in the Hokuriku, Kinai, Sartyō, and northern Kyūshū regions. In some areas in these regions, it reached 90 per cent. Tanaka Kōji, 'Kinsei ni okeru Shūyaku Inasaku no Keisei', Watanabe Tadayo (ed.), Ine no Ajiashi, vol. 3, Shōgakukan, Tōkyō, 1987, pp. 320-22.

6. 'Labour intensity' has long been seen as a feature of Japanese agriculture, particularly from the eighteenth century onwards. The spread of double cropping and the accompanying technologies further fostered this tendency in agrarian labour. See Akimoto, 
Zen Kogyoka Jidai, pp. 27-51.

7. Shinbo and Saitō Osamu (eds.), Iwanami Nihon Keizaishi, vol. 2, pp. 15-16.

8. Hayami and Miyamoto Matao (eds.), Iwanami Nihon Keizaishi, vol. 1 , pp. 42-47, 63-64.

9. Yoshinaga Akira, 'Tokusan Shōrei to Hansei Kaikaku', Asao Naohiro, Ishii Susumu, et. al. (eds.), Iwanami Köza Nihon Rekishi, vol. 11 (Kinsei 3), Iwanami Shoten, Tōkyō, 1976, pp. 42-45.

10. Lord Ishikawa of Shimodate, for instance, became a pupil of Shingaku in 1792. Ishikawa invited Nakazawa Dōni, a Shingaku leader in the Kantō region, to Shimodate to deliver a lecture in 1793. Yürinsha, a Shingaku academic centre, was founded in Shimodate later in that year. See Ishikawa (Ken), Sekimon Shingakushi, pp. 476-78.

11. As stated in Chapter 5, Shingaku followers in Kantō rural areas did not find the school's teaching effective for the restoration of deserted villages. They turned to Ninomiya instead.

12. Niki Yoshikazu, 'Nōson Fukkou no Seisan Rinri: Ninomiya Sontoku, Ōhara Yūgaku', Sugihara Shirō, Sakasai Takahito, et. al. (eds.), Nihon no Keizai Shisō Yonhyakunen, Nihon Keizai Hyōronsha, Tōkyō, 1991, p. 203.

13. Sekiyama, Kinsei Nihon no Jinkō Kōzō, p. 141.

14. Ibid., pp. 137-38. The index calculated by Ōtsuka, 'Kinsei Kōki Kita-Kantō ni okeru Shōnō Saiken', p. 38.

15. A brief comparison between ryōshu shihō and Sontoku shihō has been made by Otsuka in his 'Kinsei Kōki Kita-Kantō ni okeru Shōnō Saiken', pp. 36-39. He concluded that Ninomiya's Sontoku shihō programme appeared far more effective than ryōshu shihō practised in Nishi Takahashi village.

16. This thesis has become a commonplace in Japanese economic 
historiography. cf. Hayami and Miyamoto Matao (eds.), Iwanami Nihon Keizaishi, vol.1. Also, Iinuma Jiro, Sekai Nōgyō Bunkashi, Yasaka Shobō, Kyōto, 1983.

17. Kaihō Seiryō, 'Goshūdan', Kuranami Shōji (ed.), Kaihō Seiryō Zensh̄u, Yachiyo Shuppan, Tőkyo, 1976, p. 132.

18. NSZ, vol. 10, p. 807.

19. Ibid., pp. 791-93.

20. Ibid., p. 810.

21. Ibid., pp. 797-802.

22. Ibid., pp. 831-33.

23. Ibid., pp. 803-804, 831-33.

24. NSZ, vol. 13, p. 14.

25. Saitō Takayuki, 'Ninomiya Sensei Goroku vol. 1, No. 6', NSZ, vol. 36, pp. 343-44.

26. NSZ, vol. 3, p. 196.

27. Ibid., pp. 195-200.

28. See note 36 of this chapter.

29. Sasaki Junnosuke and Unno Fukuju, 'Ninomiya Sontoku to Bakumatsu no Nōsei Kaikaku', Bunka Hyōron (March, 1978), p.122.

30. The details of the Hōtoku loan system have been studied by Sasai Shintarō, and more recently, by economic historians Ōtō, Ōtsuka, and Niki. See Ōtō, 'Kantō Nōson no Kōhai to Sontoku Shuhō', pp. 166-184; Ōtsuka, 'Kinsei Kōki Kita-Kantō ni okeru Shōnō Saiken', pp. 44-50; and Niki, 'Odawarahan Kamado Shinden Mura', pp. 146-50.

31. NSZ, vol. 10, pp. 856-951. Also, Yūzū Muri Toki Kashichō recorded the system of interest-free loans. The records show that one household could borrow up to 1 ryō at any one time. Ninomiya Sontoku-Ō Zenshū Kankōkai (ed.), Kaisetsu Ninomiya 


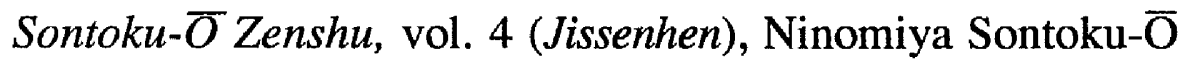
Zenshū Kankōkai, Tōkyō, 1937, pp.144-45. (abbreviated to 'KNSOZ' hereafter) Risoku Tsuki Kashikin Hikaechö recorded the system of low-interest loans, mainly to aid low-income peasant households; it also assisted poor households who had used up their initial assistance. Ibid., pp. 145-46.

32. NSZ, vol. 10 , pp. 856-57.

33. The records show that all loans were made to the head of the household, except the loans to Enzō, Senji, and Heiji. NSZ, vol. 11, pp. 43-55. This fact is revealed through cross-reference of the list of the names of lessees in the records and the 'Shümon Aratamechō' of the domain. Ibid., pp. 439-50. Moreover, while Enzō was not a household head, he was married, and had two daughters. He was the elder brother of Mataji, the head of a big household with nine menbers, and thus was like a leader of a quasi-family unit within Mataji's household. Ibid., p. 442. In sum, according to the interest-free loan record of Bunsei 7, sixteen out of eighteen loans were offered to heads of production units in Tonuma village, most of them being heads of households.

34. $N S Z$, vol. 10 , p. 810 .

35. Ibid., pp. 811-15. NSZ, vol. 12, pp. 372, 413, 451.

36. The 'Toyoda rebellion' was a small-scale protest against the shiho programme. It occurred in 1828 , and resulted in Ninomiya's departure from Sakuramachi the following year.

Production in Sakuramachi increased in the first six years of shiho (1822-27), while the programme was accompanied by the intensification of labour. A group of peasants in the domain felt discontented with this, and participated in a small-scale rebellion led by Toyoda Shōsaku in 1828 . Toyoda was a samurai, who was sent from Odawara in 1828 in support of Ninomiya's leadership in 
Sakuramachi. In Odawara, he was ranked higher than Ninomiya, who by then had been promoted from peasant to retainer in the domain hierarchy. However, the apparent success in Sakuramachi under Ninomiya had earned him a recognition higher than that granted to Toyoda. Immediately after his arrival, Toyoda was deeply dissatisfied about this. Several peasants who felt uneasy with such radical economic measures as a reward system (which involved villagers' evaluation of themselves) supported Toyoda in carrying out a protest against Ninomiya's instructions. Thus, Toyoda supporters refused to attend any of the economic projects in shiho in 1828. This affected both agricultural production and infrastructure development, and resulted in a sharp decline in production in Sakuramachi that year (see Table 1 in Section 2-3 of the main text).

The contrast between the dramatic production increase under shiho and its subsequent sharp decline during the protest convinced the villagers that they simply could not sustain their economy if the shiho programme were suspended. The protest caused damage to the village economy, but, in turn, shihō's success as an effective economic scheme was proven because of it.

Ninomiya left Sakuramachi on the fourth day of January the following year (1829), and began fasting at Shinshojii Temple in Narita. He was away for four months, during which time economic conditions in Sakuramachi worsened. His absence highlighted the importance of his presence to the restoration of the village and of the maintenance of the shiho programme. In the end, both the village officials and the ordinary peasants in Sakuramachi prepared letters asking for Ninomiya's return to service. NSZ, vol. 3, pp. 195-200.

Toyoda was sent back to Odawara in 1829 , only one year 
after his appointment as a Sakuramachi project leader, when Ninomiya returned to the domain to resume the shiho programme. Ibid., p.219. The so-called 'Toyoda rebellion' ended with the Sakuramachi peasants calling for Ninomiya's return to the domain and the resumption of his service.

37. NSZ, vol. 10, p. 794.

38. Ibid., pp. 794-96.

39. NSZ, vol. 13, p.14.

40. $N S Z$, vol. 6, p. 523.

41. NSZ, vol. 11, pp. 11-12.

42. KNSOZ, vol. 4, p. 140.

43. NSZ, vol. 11, pp. 292-300.

44. NSZ, vol. 12 , p. 1,248 .

45. Ibid., p. 1,251.

46. Ibid., p. 1,253.

47. See also Fukaya Katsumi, 'Hōtoku Shihō', Tochigikenshi:

Tsashihen 5, Kinsei 2, Tochigiken, Tochigi, 1984, pp. 910-11.

48. NSZ, vol. 10, pp. 1,023-1,077.

49. Ibid., pp. 1,024-25.

50. Ibid., p. 1,025.

51. Ibid., p. 1,027.

52. Morita Shirō, Ninomiya Sontoku, p. 136.

53. Fukuzumi, 'Ninomiya-Ō Yawa vol. 2, No.25', NSZ, vol. 36, p. 691.

54. Ibid., p. 694.

55. NSZ, vol. 6, pp. 240-41.

56. NSZ, vol. 3, p. 218. 1830 was the first year of Tenpō. But the letter was recorded to have been dispatched in 'Bunsei 13'.

57. KNSOZ, vol. 4, pp. 151, 153-57.

58. NSZ, vol. 10 , p. 1,044 . 
59. KNSOZ, vol. 4, pp. 152-53.

60. NSZ, vol. 11, pp. 110-12.

61. Ibid., pp. 113-24.

62. NSZ, vol. 10, p. 857 . The amount spent in ryō was calculated by Sasai Shintarō.

63. Nakai Nobuhiko, Ōhara Yūgaku (Jinbutsu Sōsho), Yoshikawa Kōbunkan, Tōkyō, 1963, pp. 152-8.

64. For Ōkura Nagatsune, see Smith, Native Sources of Japanese Industrialization, chapter 8 .

65. NSZ, vol. 6, p. 10.

66. No record can be found of Ninomiya's direct contact with Ōkura. However, Ninomiya's enthusiasm regarding technological education is apparent from the 'Memoirs'. In No. 135 of the 'Memoirs', for instance, his detailed instructions for the timing of fertiliser application is recorded. NSZ, vol. 36, p. 380.

67. NSZ, vol. 6, p. 14.

68. Nōgyō Hattatsushi Chōsakai (ed.), Nihon Nōgyō Hattatsushi: Supplementary, vol. 2, Chuō Kōronsha, Tōkyō, 1981 (first published in 1959), pp. 233-49.

69. Sugano Noriko, 'Tenpōki Kasō Nōmin no Sonzai Keitai', Rekishigaku Kenkyū, 365 (October, 1970), pp. 30-31.

70. Ōtsuka, 'Kinsei Kōki Kita-Kantō ni okeru Shōnō Saiken', esp. pp. 47-49.

71. See, for instance, Nishikawa Shunsaku, 'The Economic Studies of Chōshū on the eve of industrialization', The Economic Studies Quarterly, 38 (December, 1987), pp. 323-37, and T.C. Smith, Native Sources of Japanese Industrialization.

72. Ōtō Osamu's research, for instance, shows that the poorer peasants were actually favoured by the rice supply scheme. See Ōtō Osamu, 'Mura no Kōhai to Sontoku Shuhō', Oyamachōshi, 
vol. 2, Kinsei Shiryōhen 1, Oyamachō, Shizuoka, 1991, pp.

930-35.

73. NSZ, vol. 12, pp. 169-94.

74. Ibid., pp. 784.

75. Ibid., pp. 185, 186.

76. Ninomiya also formulated plans for the pursuit of extra tasks. A plan for daily rope making was called Hikake Nawanai Shudanchō. The Shudanchō of 1838, introduced in Sanshinden Shiho in Kamonomiya, Odawara, estimated the annual earnings of the household from making rope. The Shudancho suggests that a household could earn 59 ryo per annum if it made five portions of rope a day. The formula showed a means of earning cash even for the elderly, the sick and the weak; through it they could stand on their own feet, and make a partial contribution to the restoration of the village economy. See Kodama Kōta, 'Ningen to Daichi tono Taiwa', Kodama Kōta (ed.), Nihon no Meicho, vol. 26: Ninomiya Sontoku, Chū̄ Kōronsha, Tōkyō, 1970, p. 538.

77. Morita, Ninomiya Sontoku, p. 13.

78. Fukaya, Hyakushō Naritachi, p. 129.

79. NSZ, vol. 6, p. 910.

80. Ōtō, 'Mura no Kōhai to Sontoku Shuhō'. Also, Kumakawa Yumiko, 'Ninomiya Kinjirō no Shihō ni Kansuru Ichi Kōsatsu', Jinbun Ronsh $\bar{u}$ (Shizuoka University), 25 (1974).

81. NSZ, vol. 10, pp. 1,021-23.

82. $N S Z$, vol. 12 , pp. 346-55. The provision of rice assistance for the nourishment of children was also a common scheme in some ryōshu shihō programmes. See Nagano Hiroko, 'Kansei no Jidai', Hayashi Hideo (ed.), Komonjo no Kataru Nihonshi, vol. 7: Edo Kōki, Chikuma Shobō, Tokyō, 1989, p. 159.

83. NSZ, vol. 6, p. 909. For Ninomiya's discourse of a similar 
tenor, see $N S Z$, vol. 12, p. 80.

84. NSZ, vol. 6 , p. 187. Letters admiring the shiho programme could be found also in Ibid., pp. 605, 607, 616, 770, 800, 822, 832,843 , and in $N S Z$, vol. 12 , pp. 78-83.

85. NSZ, vol. 12, p. 371 .

86. NSZ, vol. 10, p. 796 .

87. NSZ, vol. 12 , pp. 783-87.

88. The pace of population increase in Sakuramachi has been studied by Ōtsuka, 'Kinsei Kōki Kita-Kantō ni okeru Shōnō Saiken', pp. 37-38.

89. NSZ, vol. 10 , p. 810 .

90. NSZ, vol. 6, p. 8.

\section{Chapter 8}

1. Saito Takayuki, 'Ninomiya Sensei Goroku vol. 2, No. 160', $N S Z$, vol. 36, p. 385 .

2. Tanaka, 'Kinsei ni Okeru Shūyaku Inasaku no Keisei', p. 332. Akimoto, Zen Kōgyōka no Jidai, Chapter 3.

3. See 'Diagram D: "Ten's Order of Annual Yield" (annual production schedule)' introduced in Chapter 6.

4. See discussion in section 4-2 in Chapter 7.

5. Smith, Native Sources of Japanese Industrialization, p. 183. Sanpei Matazaemon, a leader of the Sakuramachi project, was an admirer of the agricultural technology of Okura Nagatsune. But even Sanpei sensed Ōkura's reluctance to focus on the actual process of application and the close monitoring of his technology to the locality. $I B Z$, vol. 6, p. 14 .

6. Ibid., p. 181.

7. A school that has recently emerged within the history of technology studies, termed 'social constructivist', has disassociated 
itself from the mainstream thesis of technological development, namely, 'technological heroism', which focuses on the individual innovator (or 'genius') as the central explanatory concept of technological development. See D. MacKenzie and J. Wajcman (eds.), The Social Shaping of Technology, Open University Press, Milton Keynes, 1985. W.E. Bijker, T.P. Hughes, and T. J. Pinch (eds.), The Social Construction of Technological Systems, MIT (Massachusetts Institute of Technology) Press, Cambridge (Massachusetts), 1987. N. Rosenberg, 'Technological Interdependence in the American Economy', Technology and Culture, 20-1 (January, 1979), esp., pp. 32-40. They also marginalised technological determinism. The scholars of this school concentrate on the social factors that shaped technological change.

8. N. Rosenberg, Inside the Black Box: Technology and Economics, Cambridge University Press, Cambridge, 1982, esp., pp. 120-40.

9. See Ōtsuka, 'Kinsei Kōki Kita-Kantō ni okeru Shōnō Saiken', and Niki, 'Odawarahan Kamado Shinden Mura'. For work in English emphasising the 'communal' element of the thought of Ninomiya, see Wm. T. de Bary, et. al. (eds.), Sources of Japanese Tradition, vol. 1, Columbia University Press, New York, 1958, p. 74.

10. As Morita Shirō argues, the system itself had the psychological effect on the villagers of motivating them to work. See the discussion in section 3-1 of the preceding chapter.

11. Ōtsuka, 'Kinsei Kơki Kita-Kantō ni okeru Shōnō Saiken', p. 36 . 


\section{Conclusion}

1. Norman, E.H., And̄ Shōeki and the Anatomy of Japanese Feudalism, University Publication of America Inc., Washington, D.C., 1979 (first published in 1949), chapters IV and VI. Matsumoto Sannosuke, 'Andō Shōeki', Sagara Toru, et. al. (eds.), Edo no Shisōka Tachi, vol. 2, Kenkyūsha, Tōkyō, 1979.

2. Kaihō Seiryō, 'Keikodan', Kuranami (ed.), Kaihō Seiryō Zensh $\bar{u}$.

3. Saitō Osamu, Shōka no Sekai Uradana no Sekai. Day labourers and other urban workers in the cities of Tokugawa Japan have recently been studied in detail by G.P. Leupp, Servants, Shophands, and Laborers in the Cities of Tokugawa Japan, Princeton University Press, Princeton, 1992.

4. See, for instance, R.N. Bellah, Tokugawa Religion, MorrisSuzuki, T., A History of Japanese Economic Thought, Routledge, London, 1989, chapter 1.

5. Morris-Suzuki, Ibid., p. 11.

6. Similar agreements were concluded in thirteen villages and towns of Tōtōmi within five years from 1848. NSZ, vol. 27, pp. 728-37. The agreement in Shimo-Ishida village is not listed in $N S Z$. It is recorded, however, in Sagiyama Kyöhei, Hōtoku Kaitaku-sha, Agoin Gidō, Dai Nihon Hōtokusha, Kakegawa, 1963, pp. 31-32.

7. Unno Fukuju argues that Agoin was the first Hotoku member to attempt to transplant the advanced technology of the Kinai region. Unno Fukuju, 'Enshū Hōtoku Shugi no Seiritsu', Sundai Shigaku, 37 (1975), p. 57. But, as we saw in section 4-2 of Chapter 7, there had already been communication between a Hōtoku member and Ōkura Nagatsune, a foremost agricultural technologist with a good knowledge of the advanced technology of 
the Kinai, as early as 1829 .

8. NSZ, vol. 27 , p. 857.

9. Ibid., pp. 817-18.

10. Ibid., p. 726.

11. See note 1 , Chapter 7 .

12. Shizuokaken Nōkai (ed.), Shizuokaken Kangyō Tōkei

(1915), Shizuokaken, Shizuoka, pp. 62-82.

13. Saitō Osamu, 'Hōtokusha Undō no Kuronorojii', Mita Gakkai Zasshi, 64-8 (A Supplement; 1971), p. 738.

14. Ibid., pp. 734-41, 746.

15. Sugihara Shirō and Chō Yukio (eds.), Nihon Keizai Shisōshi Dokuhon, Tōyō Keizai Shinpōsha, Tōkyō, 1979, pp. 81-82.

16. Karasawa Tomitarō, Kyōkasho no Rekishi: Kyōkasho to Nihonjin no Keisei, Sōbunsha, Tōkyō, 1956, pp. 672-87.

17. Hiramatsu Nobuhisa, 'Tsukurareta Ninomiya Sontoku: Mohanteki Jinbutsuzō no Rufu ni Tsuite', Yoshida Mitsukuni (ed.), Jyūkyūseiki Nihon no Jōhō to Shakai Hendō, Kyōto Daigaku Jinbun Kagaku Kenkyusho, Kyōto, 1985.

18. Ōtō Osamu, 'Ishin, Bunmei Kaika to Okada Ryōichirō no Genron vol. 1', Rekishi, 66 (September, 1986), p. 2.

19. Chuō Hōtokukai (ed.), Shimin, vols. 1-1 (1906) 39-9 (1944); vols. 40-1 (1946) 40-5 (1946).

20. The life and thought of Ninomiya and his educational efforts were discussed in the column 'shich $\bar{o}$ '. The successful use of new technology and the adoption of new economic institutions were discussed in the columns 'setsuen' and 'kōwa'.

21. For instance, a visit to vocational schools in Dresden by Hōtoku members was reported in volumes 1-2 and 1-3 (both published in 1906) of Shimin. 


\section{Bibliography}

\section{Primary sources}

Works by Ishida and his disciples:

Ishida Baigan

'Tohi-Mondō', 'Seikaron', 'Ishida Sensei Goroku', 'Ishida

Sensei Jiseki', Shibata Minoru (ed.), Ishida Baigan Zensh $\bar{u}$

(IBZ), vols. 1 and 2, Sekimon Shingakukai, Tōkyō, 1955.

Teshima Toan

'Jijo Nemuri Samashi', 'Zenkun', 'Kaiyū Taishi', Meirinsha (ed.),

Teshima Toan Zenshū, Meirinsha, Kyōto, 1931.

Nakazawa Dōni

'Dōni-Ō Dōwa', Shibata Minoru (ed.), Iwanami Nihon Shisō

Taikei, vol. 42: Sekimon Shingaku, Iwanami Shoten, Tōkyō, 1971.

Uekawa Kisui

'Kyōchō Gorakusha Shingaku Shōden no Zu', Ibid., pp. 207-32.

Works by Ninomiya and his disciples:

Ninomiya Sontoku

'Sansai Hōtoku Kinmōroku', 'Ō en kyō', 'Banbutsu Hatsugenshū',

'Hyakushu Rinnekyō', 'Tenmei Shichigenzu', 'Sansei Kantsū

Godōden', Sasai Shintarō (ed.), Ninomiya Sontoku Zenshü

(NSZ) vol. 1, Ninomiya Sontoku Igyō Senyōkai, Shizuoka, 1927-1932.

Fukuzumi Masae

'Ninomiya-Ō Yawa', NSZ vol. 36.

Saitō Takayuki

'Ninomiya Sensei Goroku', NSZ vol. 36. 
Documents regarding the shiho programme in Sakuramachi: NSZ, vols. 10-13.

Letters by Ninomiya, his disciples, and shihō leaders: NSZ, vols. 3-5.

Other correspondences by Ninomiya, his disciples, and shihō leaders: $N S Z$, vols. 6-9.

Chuō Hōtokukai (ed.), Shimin, vols. 1-1 (1906) 39-9 (1944); vols. 40-1 (1946) 40-5 (1946).

English translations of the works of Ishida, Ninomiya and their disciples:

Bellah, R.N., 'A Memoir of Our Teacher, Ishida ("Ishida Sensei Jiseki")', R.N. Bellah, Tokugawa Religion, The Free Press, New York, 1985 (first published in 1957).

Beonio-Brocchieri, P., 'Ishida Baigan: Seiri Mondō ("Seiri Mondō no Dan" in Ishida's Tohi-Mondō) - Dialogues on Human Nature and Natural Order', V.S. Agrawala, et. al. (eds.), Orientalia Romana 2, Instituto Italiano Per Il Medio Ed Estremo Oriente, Roma, 1967.

Yamagata Isō, Sage Ninomiya's Evening Talks ("Ninomiya-Ō Yawa"), Tokunō Kyōkai, Tōkyō, 1937.

Yoshimoto Tadasu, A Peasant Sage of Japan: The Life and Work of Sontoku Ninomiya ("Hōtokuki"), Longmans, Green \& Co., London, 1912.

Other primary sources:

Kaihō Seiryō, 'Keikodan' and 'Goshūdan', Kuranami Shōji (ed.), Kaihō Seiryō Zensh̄̄, Yachiyo Shuppan, Tōkyō, 1976.

Kawachiya Yoshimasa, 'Kawachiya Yoshimasa Kyūki', Nomura Yutaka and Yui Kitarō (eds.), Kawachiya Yoshimasa Kyüki, 
Seibundō Shuppan, Ōsaka, 1970 (first published in 1955). Miura Baien, 'Jihi Mujin Kō', (Copyright by the Center for East Asian Studies, University of Chicago) Readings in Tokugawa Thought: Selected Papers, vol. 9, The Center for East Asian Studies, University of Chicago, 1993. Translations by T. Najita, et. al.

Muro Kyūsō, 'Fubōshō', Takimoto Seiichi (ed.), Nihon Keizai

Taiten, vol. 6, Keimeisha, Tōkyō, 1928-30.

Ogyu Sorai, 'Seidan, vol. 2 ' and 'Taiheisaku', Nishida Taichiro,

Maruyama Masao, et. al. (eds.), Iwanami Nihon Shisō Taikei

vol. 36: Ogȳ̄ Sorai, Iwanami Shoten, Tōkyō, 1973.

Tamura Yoshishige, 'Yoshishige Ikun', Iinuma Jirō, et. al. (eds.),

Nihon Nősho Zenshū vol. 21, Nơsangyoson Bunka Kyōkai, Tokyo, 1981.

\section{Secondary sources (Japanese literature)}

Adachi Seikō, Yamazaki Enkichi, Riburo Pooto, Tōkyō, 1992.

Akimoto Hiroya, Zen Kōgyōka Jidai no Keizai, Mineruva Shobō, Kyōto, 1987.

Aoki Masahiko, Information, Incentives, and Bargaining in the Japanese Economy, Cambridge University Press, Cambridge, 1988 (printed in the U.S.).

Aoki Michio, 'Kinjirō to Sontoku' in Aoki, Bunka Bunseiki no

Minshū to Bunka, Bunka Shobō Hakubunsha, Tōkyō, 1985.

Asao Naohiro, 'Kōgi to Bakuhan Ryōshusei', Rekishigaku Kenkyūkai and Nihonshi Kenkyūkai (eds.), Kōza Nihon Rekishi, vol. 5 (Kinsei 1), Tōkyō Daigaku Shuppankai, Tōkyō, 1985.

Bitō Masahide, 'Tokugawa Jidai no Shakai to Seiji Shisō no

Tokushitu', Shisö, 685 (July, 1981).

Denda Isao, Gōnō (Kyōikusha Rekishi Shinsho), Kyōikusha, Tōkyō, 
1978.

Dore, R.P., Iwata Ryūshi, Morikawa Hidemasa, et. al., 'Tokushū:

Nihonteki Keieiron no Saikentō', Keizai Hyöron, 30-7 (July, 1981).

Fukawa Seiji (ed.), Kinsei Shomin no Ishiki to Seikatsu,

Nōsangyoson Bunka Kyōkai, Tōkyō, 1984.

Fukaya Katsumi, 'Hyakushō Denki ni arawareta Kinseiteki Hyakushō

Jinkaku', Sōdai Daigakuin Bungaku Kenkyūkä Kìō, 2 (March, 1980).

, 'Hōtoku Shihō', Tochigikenshi: Tsūshihen 5,

Kinsei 2, Tochigiken, Tochigi, 1984.

, 'Kinsei Kazoku to Kyōdōtai', Rekishi Hyōron, 441

(January, 1987).

, Hyakushō Naritachi, Hanawa Shobō, Tōkyō, 1993. and Matsumoto Shirō (eds.), Kōza Nihon Kinseishi

vol. 3, Yühikaku, Tōkyō, 1980.

Fukuda Ajio, Kanōsei to shite no Mura Shakai: Rōdō to Jōhō no

Minzokugaku, Seikyūsha, Tōkyō, 1990.

Furushima Toshio, Kyōdōtai no Kenkȳ̄ (Furushima Toshio

Chosakushū 7), Tōkyō Daigaku Shuppankai, Tōkyō, 1983. , Nōsho no Jidai, Nōsangyoson Bunka Kyōkai, Tōkyō,

1980.

Haga Noboru, Bakumatsu Kokugaku no Tenkai, Hanawa Shobō,

Tōkyō, 1963.

, 'Nihon no Nōhon Shugi', Shigaku Sōsho, vol. 1, Tōkyō

Kyōiku Shuppan Sentaa, Tōkyō, 1982.

Hasegawa Shinzō, 'Bunseiki Shimodatechō ni okeru Sekimon

Shingaku no Seinen Kyōka no Jissai', Ibarakiken-shi Kenkyü, 16 (1970).

, 'Kita-Kantō Nōson no Kōhai to Nōminso', Murakami 
Tadashi (ed.), Ronshü Kantō Kinseishi no Kenkyü, Meicho Shuppan, Tökyō, 1984.

Hasekura Tamotsu, 'Karasuyamahan ni okeru Bunsei, Tenpō Kaikaku to Hōtoku Shihō no Ichi', Nihon Rekishi, 338 (July, 1976). , 'Odawarahan ni okeru Hōtoku Shihō ni tsuite', Kitajima Masamoto (ed.), Bakuhansei Kokka Kaitai Katei no Kenkyū, Yoshikawa Kōbunkan, Tōkyō, 1978.

Hayami Akira and Miyamoto Matao (eds.), Iwanami Nihon

Keizaishi, vol. 1 (Keizai Shakai no Seiritsu), Iwanami Shoten, Tōkyō, 1988.

Hayashi Reiko, 'Shimodatehan ni okeru Sontoku Shuhō no Haikei',

Ibarakiken-shi Kenkyū, 6 (November, 1966).

Hazama Hiroshi, Nihon Rōmu Kanrishi Kenkyū, Ochanomizu Shobō, Tōkyō, 1978 (first published in 1964).

Hiraishi Naoaki, 'Kinsei Nihon no "Shokugyō"kan', Tōkyō Daigaku

Shakai Kagaku Kenkyūsho (ed.), Gendai Nihon Shakai, vol. 4

(Rekishiteki Zentei), Tōkyō Daigaku Shuppankai, Tōkyō, 1991.

Hiramatsu Nobuhisa, 'Tsukurareta Ninomiya Sontoku: Mohanteki

Jinbutsuzō no Rufu ni Tsuite', Yoshida Mitsukuni (ed.),

Jyükyūseiki Nihon no Jōhō to Shakai Hendō, Kyōto Daigaku

Jinbun Kagaku Kenkyūsho, Kyōto, 1985.

, 'Hōtoku Shisō no Tenkai to Kessha Undō', Nōringyō

Mondai Kenkyū, 74 (20-1; March, 1984).

Ichimura Yūichi, 'Shingaku Dōwa to Komyunikeishon', Bitō

Masahide Sensei Kanreki Kinenkai (ed.), Nihon Kinseishi Ronsō,

vol. 2, Yoshikawa Kōbunkan, Tōkyō, 1984.

Iinuma Jirō, Sekai Nōgyōo Bunkashi, Yasaka Shobō, Kyōto, 1983.

, 'Igirisu Jyūhasseiki ni okeru Sonraku Kōzō', Iinuma Jirō, Nōgyō Kakumei no Kenkyū, Nösangyoson Bunka Kyōkai, Tōkyō, 1985. 
Imai Atsushi and Furuta Shōkin (eds.), Ishida Baigan no Shisō,

Perikansha, Tōkyō, 1979.

Imamura Hitoshi, Rōdō no Ontorogii, Keisō Shobō, Tōkyō, 1981.

Ishikawa Ken, Sekimon Shingakushi no Kenkyū, Iwanami Shoten,

Tökyō, 1938. , Ishida Baigan (Nihon Kyōiku Sentetsu Soshō), Bunkyō

Shoin, Tokyo, 1943.

, Ishida Baigan to Tohi-Mondō (Iwanami Shinsho),

Iwanami Shoten, Tōkyō, 1968.

, Shingaku Kyōka no Honshitsu narabi ni Hattatsu,

Seishisha, Tökyō, 1982 (first published in 1931 by Shōkasha,

Tokyō).

Ishikawa Matsutarō, Hankö to Terakoya (Kyōikusha Rekishi

Shinsho), Kyöikusha, Tokyo, 1978.

Iwashiro Takuji, Mizumoto Kunihiko, Morishita Toru, et. al., 'Shō-

tokushū: Kinsei no 'Yaku' to Minshü', Nihonshi Kenkyü, 324

(August, 1989).

Kamata Satoru (ed.), Nihonjin no Shigoto, Heibonsha, Tökyo, 1986.

Karasawa Tomitarö, Kyökasho no Rekishi: Kyōkasyo to Nihonjin no

Keisei, Sobunsha, Tokyo, 1956.

Kataoka Nobuyuki, 'Edoki no Shogyō, Shōnin Kyōiku, Shōningaku',

Keizai Keiei Ronshū (Ryūkoku University), 23-3 (December, 1983).

Kimura Motoi, Nihon Sonrakushi, Kobundō, Tokyo, 1978. (ed.), Ōhara Yügaku to sono Shühen, Yagi Shoten, Tōkyō, 1986.

Kodama Kōta, 'Ningen to Daichi tono Taiwa', Kodama Kōta (ed.), Nihon no Meicho: Ninomiya Sontoku, Chuo Köronsha, Tökyo, 1970.

Kouchi Hachiro, 'Hanada Mura no Sontoku Shiho' 1 8, Sekijocho 
-shì Hensan linkai (ed.), Sekijōchō no Rekishi, 1 (March, 1981) 8 (March, 1988).

and Mori Yutaka, 'Nikkō Jinryō no Hōtoku Shihō

Kaishi', Imaichishi-shi vol. 1, Tsūshihen, Beppen I, Imaichishi, Tochigi, 1980.

Kumakawa Yumiko, 'Ninomiya Kinjirō no Shihō ni Kansuru Ichi

Kōsatsu', Jinbun Ronsh̄̄ (Shizuoka University), 25 (1974).

Maruyama Masao, Nihon Seiji Shisōshi Kenkyū, Tōkyō Daigaku

Shuppankai, Tōkyō, 1952.

Matsumoto Sannosuke, 'Andō Shōeki', Sagara Tōru, et. al. (eds.),

Edo no Shisōka Tachi, vol. 2, Kenkyūsha, Tōkyō, 1979.

Minamoto Ryōen, Kinsei Shoki Jitsugaku Shisō no Kenkyü,

Sōbunsha, Tōkyō, 1980.

(ed.), Kata to Nihon Bunka, Sōbunsha, Tōkyō, 1992.

Minegishi Kentarō, Kinsei Mibunron, Azekura Shobō, Tōkyō, 1989.

Miyamoto Mataji, 'Sekimon Shingaku to Shōnin Ishiki', Shingaku (a

periodical of Sekimon Shingakukai), 2 (1942). This article has

been reprinted in Miyamoto Mataji, Kinsei Nihon Keieishi Ronkō

published in 1979.

, Kinsei Shōnin Ishiki no Kenkȳu: Kakun Oyobi

Tensoku to Nihon Shōnindō, Yühikaku, Tōkyō, 1942.

, Kamigata no Kenkyū, Seibundō, Ōsaka, 1977.

, Kinsei Nihon Keieishi Ronkō, Tōyō Bunkasha, Kyöto,

1979.

and Sakudō Yōtarō (eds.), Sumitomo no Keieishiteki

Kenkȳu, Jikkyō Shuppan, Tōkyō, 1979.

Mizumachi Kiyoshi, Ninomiya Sontoku-ō no Dōtoku Keizai Shiso,

Meirōsha, Tōkyō, 1937.

Mizumoto Kunihiko, 'Mura Kyōdōtai to Mura Shihai', Rekishigaku

Kenkyūkai and Nihonshi Kenkyūkai (eds.), Kōza Nihon Rekishi, 
vol. 5 (Kinsei 1), Tōkyō Daigaku Shuppankai, Tōkyō, 1985. Morishita Tōru, 'Kinsei no Fusei ni okeru 'Yaku' Hensei to Rōdō Katei', Shakai Keizai Shigaku, 58-2 (June, July, 1992). Morita Shirō, Nihon no Mura (Asahi Sensho), Asahi Shinbunsha, Tōkyō, 1978. , Ninomiya Sontoku (Asahi Sensho), Asahi Shinbunsha, Tōkyō, 1989 (first published in 1975).

Nagano Hiroko, 'Kansei no Jidai', Hayashi Hideo (ed.), Komonjo no Kataru Nihonshi, vol. 7: Edo Kōki, Chikuma Shobō, Tōkyō, 1989.

Nakai Nobuhiko, Ōhara Yūgaku (Jinbutsu Sōsho), Yoshikawa

Kōbunkan, Tōkyō, 1989 (first published in 1963). and Naramoto Tatsuya (eds.), Iwanami Nihon Shisō

Taikei, vol. 52: Ninomiya Sontoku, Ōhara Yūgaku, Iwanami Shoten, Tōkyō, 1973.

Nakamura Hajime, 'Suzuki Shōsan, 1579-1655, and the Spirit of Capitalism in Japanese Buddhism', Monumenta Nipponica, 22,1-2 (1967).

Nakamura Yūjïrō and Kimura Motoi (eds.), Sonraku Hōtoku Jinushisei, Tōyō Keizai Shinpōsha, Tōkyō, 1976.

Nakane Chie, Tate Shakai no Ningen Kankei, Ködansha, Tōkyō, 1967.

Naramoto Tatsuya, Ninomiya Sontoku (Iwanami Shinsho), Iwanami Shoten, Tōkyō, 1959.

, 'Ninomiya Sontoku: Sansai Hōtoku Kinmōroku wo chushin to shite', Shisō, 548 (February, 1970).

Niki Yoshikazu, 'Nōson Fukkō no Seisan Rinri: Ninomiya Sontoku, Ōhara Yūgaku', Sugihara Shirō, Sakasai Takahito, et. al., (eds.), Nihon no Keizai Shisō Yonhyakunen, Nihon Keizai Hyōronsha, Tōkyō, 1991. 
, 'Odawarahan Kamado Shinden Mura no Hōtoku

Shihō ni Tsuite', Rikkyō Keizaigaku Kenkyū, 45-3 (January, 1992).

, 'Hōtoku Shisō no Jyuyō ni tsuite - Kobayashi Heibei

wo Jirei to shite', Rikkyō Keizaigaku Kenkȳ̄, 47-2 (October, 1993).

Ninomiya Sontoku-Ō Zenshū Kankōkai (ed.), Kaisetsu Ninomiya

Sontoku- $\bar{O}$ Zensh $\bar{u}$, vol.4 (Jissenhen), Ninomiya Sontoku-Ō

Zenshū Kankōkai, Tōkyō, 1937.

Ninomiya Sontoku Seitan Nihyakunen Kinen Jigyōkai and Hōtoku Jikkō linkai (eds.), Sontoku Kaiken, Yurindō, Yokohama, 1987.

Nōgyō Hattatsushi Chōsakai (ed.), Nihon Nōgyō Hattatsushi:

Supplementary, vol. 2, Chuō Kōronsha, Tōkyō, 1981 (first

published in 1959).

Nojiri Shigeo, Nömin Rison no Jisshōteki Kenkyū, Iwanami Shoten, Tōkyō, 1942.

Odaka Kunio, Nihonteki Keiei: Sono Shinwa to Genjitsu (Chūkō

Shinsho), Chuō Kōronsha, Tökyō, 1984.

Ōishi Shinzaburō, Kinsei Sonraku no Kōzō to Ie Seido,

Ochanomizu Shobō, Tōkyō, 1968.

Oka Mitsuo, Nihon Nōgyō Gijutsushi: Kinsei kara Kindai e,

Mineruva Shobō, Kyōto, 1988.

Okutani Matsuji, Ninomiya Sontoku to Hōtokusha Undō, Kōyō

Shoin, Tökyō, 1936.

Orihara Hiroshi, 'Edoki ni okeru Shōri Kōteiron no Keisei: Ishida

Baigan to Yamagata Bantō', Keiai Daigaku Kenkyü Ronsh $\bar{u}, 42$

(September, 1992).

Ōshima Mario, 'Kinsei Nōmin Shihai to Kazoku, Kyōdotai',

Nihonshi Kenky $\bar{u}, 308$ (1988). 
Ōtō Osamu, 'Mibun to Ie', Fukaya Katsumi and Matsumoto Shirō (eds.), Kōza Nihon Kinseishi, vol. 3, Yūhikaku, Tōkyō, 1980. , 'Kantō Nōson no Kōhai to Sontoku Shihō', Shiryōkan

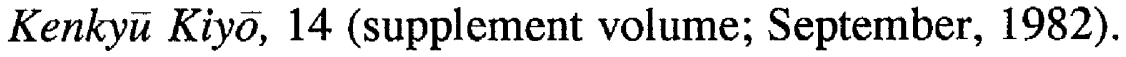
, 'Ishin, Bunmei Kaika to Okada Ryöichiro no Genron 1', Rekishi, 66 (September, 1986). , 'Mura no Kōhai to Sontoku Shuhō', Oyamachōshi, vol. 2 (Kinsei Shiryōhen 1), Oyamachō, Shizuoka, 1991. Ōtsuka Eiji, 'Kinsei Kōki Kita-Kantō ni okeru Shōnō Saiken to Hōtoku Kinyū no Tokushitsu', Nihonshi Kenkȳ̄, 263 (July, 1984). , 'Hōtoku Shihō Seiritsuki ni okeru Shomondai', Jinbun Kagaku Kenkȳ̄ (Nagoya University), 15 (March, 1986). Pak, T., 'Richō Kōki ni okeru Seiji Shisō no Tenkai', Kokka Gakkai Zasshi, 88-11, 12 (1975).

Rekishigaku Kenkyūkai and Nihonshi Kenkyūkai (eds.), Kōza Nihon Rekishi, vol. 5 (Kinsei 1), Tōkyō Daigaku Shuppankai, Tōkyō, 1985.

Sagara Töru, et. al. (eds.), Edo no Shisōka Tachi, vols. 1, 2,

Kenkyūsha, Tōkyō, 1979.

Sagiyama Kyōhei, Hōtoku Kaitakusha, Agoin Gidō, Dai Nihon Hōtokusha, Kakegawa, 1963.

Saitō Osamu, 'Hōtokusha Undō no Kuronorojii', Mita Gakkai Zasshi, 64-8 (1971: A Supplement). , Puroto Kōgyōka no Jidai, Nihon Hyōronsha,

Tōkyō, 1985. , Shōka no Sekai, Uradana no Sekai, Riburo Pooto, Tōkyō, 1987. , 'Jukuren, Kunren, Rōdō Shijō', Kawakita Minoru (ed.), Shiriizu Sekaishi eno Toi, vol. 2: Seikatsu no Gijutsu, Seisan no 
Gijutsu, Iwanami Shoten, Tōkyō, 1990.

Saitō Yasuhiko, 'Nōson Kōhaiki no Han Kōkin Kashitsuke Seisaku no Tenkai', Nihon Rekishi, 424 (September, 1983).

Sakasai Takahito, 'Sekimon Shingaku ni okeru Jissen Tetsugaku no Tenkai - Ishida Baigan to Teshima Toan', Rikkyö Keizaigaku Kenkyū, 34-3 (December, 1980).

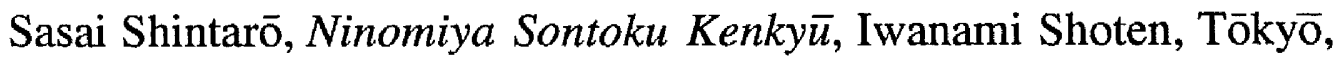
1927. , Ninomiya Sontokuden, Nihon Hyōronsha, Tōkyō,

1935.

Sasaki Junnosuke and Unno Fukuju, 'Ninomiya Sontoku to

Bakumatsu no Nōsei Kaikaku', Bunka Hyōron (March, 1978).

Sekiyama Naotarö, Kinsei Nihon no Jinkō Kōzō, Yoshikawa

Kōbunkan, Tōkyō, 1958.

Shibata Minoru, Shingaku (Nihon Rekishi Shinsho), Shibundō, Tōkyō, 1967. Baigan to sono Monrȳ̄, Mineruva Shobō, Kyōto, 1977.

Shinbo Hiroshi and Saito Osamu (eds.), Iwanami Nihon Keizaishi, vol. 2 (Kindai Seichō no Taidō), Iwanami Shoten, Tōkyō, 1989.

Shitahodo Yūkichi, Tendō to Jindō: Ninomiya Sontoku no

Tetsugaku, Iwanami Shoten, Tōkyö, 1942.

Sugano Noriko, 'Tenpōki Kasō Nōmin no Sonzai Keitai',

Rekishigaku Kenkyū, 365 (October, 1970).

Sugihara Shirō and Chō Yukio (eds.), Nihon Keizai Shisōshi

Dokuhon, Tōyō Keizai Shinpōsha, Tōkyō, 1979.

Sugihara Shirō, Sakasai Takahito, et. al. (eds.), Nihon no Keizai

Shisō Yonhyakunen, Nihon Keizai Hyōronsha, Tōkyō, 1991. Sugimura Yoshimi, Datsu Kindai no Rōdōkan, Mineruva Shobō, Kyōto, 1990. 
Takagi Shōsaku, 'Bakuhan Shoki no Mibun to Kuniyaku',

Rekishigaku Kenkyū, special edition (November, 1976).

Takebayashi Shōtarō, 'Baigan to Bantō no Shōgyōron', Kansai

Daigaku Shōgaku Ronsh̄u, 19-3, 4 (October, 1974).

Takenaka Yasukazu, 'Ishida Baigan no Shisō ni tsuite', Horie Yasuzō

(ed.), Kinsei Nihon no Keizai to Shakai, Yūhikaku, Tōkyō, 1958. , 'Teshima Toan no Chōnin Tetsugaku', Shōkei

Gakusō (Kinki University), 7-1, 2 (1961).

, Sekimon Shingaku no Keizai Shiso, Mineruva

Shobō, Kyōto, 1962.

, 'Robaato Beraa (Robert N. Bellah) no Shingakukan',

Miyamoto Mataji (ed.), Amerika no Nihon Kenkȳu, Tōyō Keizai

Shinpōsha, Tokyo, 1970.

, 'Ishida Baigan no Keiei Rinen', Keiei Shigakukai

(ed.), Keiei Shigaku, vol. 4 No. 3, Tōkyō Daigaku Shuppankai, Tōkyō, 1970.

, Nihonteki Keiei no Genryū, Mineruva Shobō,

Kyöto, 1977.

Tanaka Kōji, 'Kinsei ni okeru Shūyaku Inasaku no Keisei', Watanabe

Tadayo (ed.), Ine no Ajiashi, vol. 3, Shōgakukan, Tōkyō, 1987.

Tōkyō Daigaku Shakai Kagaku Kenkyūsho (ed.), Gendai Nihon

Shakai, vol. 4 (Rekishiteki Zentei), Tōkyō Daigaku Shuppankai,

Tōkyō, 1991.

Tsuda Hideo, 'Kyöiku no Fukyü to Shingaku', Asao Naohiro, Ishii

Susumu, et. al. (eds.), Iwanami Kōza Nihon Rekishi, vol. 12

(Kinsei 4), Iwanami Shoten, Tōkyō, 1976.

Tsukuba Tsuneharu, 'Nihon Nōhonshugi Jyosetsu', Shisō no Kagaku, 18 (June, 1960).

, 'Ōkura Nagatsune to Ninomiya Sontoku', Shisō no 
Kagaku, 35 (November, 1961). , Nihon no Nōsho, Chuō Kōronsha, Tōkyō, 1987.

Tsunasawa Mitsuaki, Nihon no Nōhon Shugi, Kinokuniya Shoten, Tōkyō, 1980.

Uesugi Mitsuhiko, 'Hōtokusha Undō no Genten: Sōshū Kataoka

Mura no Shihō wo Chūshin to shite', Shakai Kagaku Tökȳ̄, 22-3 (January, 1977). , 'Bakuseiki no Hōtoku Shihō: ŌTnogō Mura no

Shihō wo Chūshin to shite', Risshō Shigaku, 43 (February, 1978). Unno Fukuju, 'Enshū Hōtoku Shugi no Seiritsu', Sundai Shigaku, 37 (1975). and Katō Takashi (eds.), Shokusan Kōgyō to Hōtoku Undō, Tōyō Keizai Shinpōsha, Tōkyō, 1978.

Utsuki Saburō, 'Ninomiya Sontoku no Shisō no Tokushitsu to Shihō', Kaibyaku, 27-6, 1978. This article was first published in Rekishi Dōjin Köyōzaka, 4 (1977).

Watanabe Hiroshi, 'Tokugawa Zenki Jugakushi no Ichi Jōken', Kokka Gakkai Zasshi, 94-1,2 (1981).

Weber, M., Purotesutantizumu no Rinri to Shihon Shugi no Seishin, Iwanami Shoten, Tōkyō, 1991. Translated by Ötsuka Hisao from Die protestantische Ethik und Der Geist des Kapitalismus, Gesammelte Aufsatze zur Religionssoziologie, Bd. 1, 1920, SS. 17-206.

Yanabu Akira, Hon'yakugo Seiritsu Jijo (Iwanami Shinsho), Iwanami Shoten, Tōkyō, 1982.

Yasumaru Yoshio, Nihon no Kindaika to Minshu Shisō, Aoki Shoten, Tōkyō, 1974. , 'Minshū Shisōshi no Tachiba', Hitotsubashi Ronsō, 78-5 (445; November, 1977). 
Yoshinaga Akira, 'Tokusan Shōrei to Hansei Kaikaku', Asao Naohiro, Ishii Susumu, et. al. (eds.), Iwanami Kōza Nihon Rekishi, vol. 11 (Kinsei 3), Iwanami Shoten, Tōkyō, 1976.

Yu, Ying-shi, Chūgoku Kinsei no Shūkyō Rinri to Shönin Seishin, Heibonsha, Tōkyō, 1991.

\section{Secondary sources (English literature)}

Anderson Sawada, J., Confucian Values and Popular Zen: Sekimon

Shingaku in the Eighteenth Century, University of Hawaii Press, Honolulu, 1993.

Aoki Masahiko, Information, Incentives, and Bargaining in the Japanese Economy, Cambridge University Press, Cambridge (printed in the U.S.), 1988.

Applebaum, H. (ed.), WORK in Non-market and Transitional

Societies, SUNY (State University of New York) Press, Buffalo, 1984.

, Concept of Work: Ancient, Medieval, and Modern,

SUNY (State University of New York) Press, Buffalo, 1992.

Armstrong, R.C., Just Before the Dawn; the Life and Work of

Ninomiya Sontoku, Macmillan, New York, 1912.

Asao Naohiro, 'The Sixteenth-Century Unification', John W. Hall,

et. al. (eds.), The Cambridge History of Japan vol. 4,

Cambridge University Press, Cambridge, 1991.

Bellah, R.N., Tokugawa Religion, The Free Press, New York, 1985

(first published in 1957).

Berg, M., 'Women's Work, Mechanization and the Early Phases of Industrialization in England', R.E. Pahl (ed.), On Work:

Historical, Comparative \& Theoretical Approaches, Basil

Blackwell, Oxford, 1988. Reprinted from Joyce (ed.), The

Historical Meanings of Work. 
Bijker, W.E., T.P. Hughes, and T. J. Pinch (eds.), The Social Construction of Technological Systems, MIT (Massachusetts Institute of Technology) Press, Cambridge (Massachusetts), 1987. Braverman, H., Labor and Monopoly Capital: The Degradation of Work in the Twentieth Century, Monthly Review Press, New York, 1974 (first published in 1957). Briggs, A., 'Review of Thompson, The Making of the English Working Class' in Labour History, 6 (1965).

Chan, Wing-tsit (ed.), Chu Hsi and Neo-Confucianism, University of Hawaii Press, Hawaii, 1986. , Neo-Confucian Terms Explained, Columbia University Press, New York, 1986. de Bary, Wm. T., Neo-Confucian Orthodoxy and the Learning of the Mind-and-Heart, Columbia University Press, New York, 1981. , et. al. (eds.), Sources of Japanese Tradition

vol. 2, Columbia University Press, New York, 1958. and I. Bloom (eds.), Principle and Practicality:

Essays in Neo-Confucianism and Practical Learning, Columbia University Press, New York, 1979.

Dore, R.P., Education in Tokugawa Japan, Athlone Press Ltd., London, 1984 (first published in 1965). , Flexible Rigidities, Stanford University Press, Stanford, 1986.

Droppers, G., 'A Japanese Credit Association and Its Founder', Transactions of the Asiatic Society of Japan, 22, 1894.

Firth, R., 'Work and Value: Reflections on Ideas of Karl Marx', S. Wallman (ed.), Social Anthropology of Work, Academic Press, London, 1979. 
Fung, Yu-lan, 'The Philosophy of Chu Hsi', Harvard Journal of Asiatic Studies, 7 (1942-1943). Translated by D. Bodde.

Garon, S., The State and Labor in Modern Japan, University of California Press, Berkeley, 1987.

Gluck, C., 'The People in History: Recent Trends in Japanese Historiography', Journal of Asian Studies, 38-4 (November, 1978).

, Japan's Modern Myths: Ideology in the Late Meiji

Period, Princeton University Press, Princeton, 1985.

Gordon, A., The Evolution of Labor Relations in Japan: Heavy Industry, 1853-1955, Council on East Asian Studies/Harvard University Press, Cambridge (Massachusetts), 1985.

Gutman, H.G., 'Work, Culture and Society in Industrializing America, 1815-1919', Pahl (ed.), On Work: Historical, Comparative \& Theoretical Approaches.

Hall, J.H., et. al. (eds.), The Cambridge History of Japan, vol. 4, Cambridge University Press, Cambridge, 1991.

Hardacre, H., Kurozumikyō and the New Religions of Japan, Princeton University Press, Princeton, 1986.

Harootunian, H.D., Things Seen and Unseen: Discourse and Ideology in Tokugawa Nativism, University of Chicago Press, Chicago, 1988. , 'Metzger's Predicament' in the 'Review

Symposium: Thomas A. Metzger's Escape from Predicament', Journal of Asian Studies, 34-2 (February, 1980).

Johnson, D., et. al. (eds.), Popular Culture in Late Imperial China, University of California Press, Berkeley, 1985.

Joyce, P. (ed.), The Historical Meanings of Work, Cambridge

University Press, Cambridge, 1987.

Le Goff, J., Time, Work, and Culture in the Middle Ages, University 
of Chicago Press, Chicago, 1980. Translated by A. Goldhammer. Leupp, G.P., Servants, Shophands, and Laborers in the Cities of Tokugawa Japan, Princeton University Press, Princeton, 1992. MacKenzie, D. and J. Wajcman (eds.), The Social Shaping of Technology, Open University Press, Milton Keynes, 1985. Malcolmson, R.W., 'Ways of Getting a Living in Eighteenth-Century England', Pahl (ed.), On Work: Historical, Comparative \& Theoretical Approaches.

Marx, K., Capital, vol. 1, Lawrence and Wishart, London, 1983 (L\&W version first published in 1954). Das Kapital was first published in German in 1867. English edition first published in 1887. and F. Engels, 'The German Ideology', J. Cohen, E.J. Hobsbawm, et. al. (eds.), Collected Works, 5, Lawrence and Wishart, London, 1976. 'The German Ideology' was first published in German in 1845.

Middleton, C., 'The Familiar Fate of the Famulae: Gender Divisions in the History of Wage Labour', Pahl (ed.), On Work: Historical, Comparative \& Theoretical Approaches.

Mitchell, B.R. and P. Deane, Abstract of British Historical Statistics, Cambridge University Press, Cambridge, 1971. More, C., Skill and the English Working Class, 1870-1914, Croom Helm Ltd., London, 1980. , 'Skill and the Survival of Apprenticeship', S. Wood (ed.), The degradation of work?: Skill, De-skilling and the Labour Process, Hutchinson, London, 1982.

Morris-Suzuki, T., A History of Japanese Economic Thought, Routledge, London, 1989.

Najita, T., Visions of Virtue in Tokugawa Japan, University of Chicago Press, Chicago, 1987. 
and I. Scheiner (eds.), Japanese Thought in the Tokugawa Period, University of Chicago Press, Chicago, 1978.

Nakane Chie, Kinship and Economic Organisation in Rural Japan, London School of Economics/Athlone Press, London, 1967. , Japanese Society, University of California Press,

Berkeley, 1970.

Norman, E.H., Andō Shōeki and the Anatomy of Japanese

Feudalism, University Publication of America Inc., Washington, D.C., 1979 (first published in 1949).

Nosco, P. (ed.), Confucianism and Tokugawa Culture, Princeton University Press, Princeton, 1984.

Pahl, R.E. (ed.), On Work: Historical, Comparative \& Theoretical Approaches, Basil Blackwell, Oxford, 1988.

Roberts, B., R. Finnegan, and D. Gallie (eds.), New Approaches to

Economic Life, Manchester University Press, Manchester, 1985.

Roberts, J.G., Mitsui: Three Centuries of Japanese Business,

Weatherhill, New York, 1973.

Robertson, J., 'Rooting the Pine: Shingaku Methods of Organization', Monumenta Nipponica, 34-3 (Autumn, 1979).

Rosenberg, N., 'Technological Interdependence in the American

Economy', Technology and Culture, 20-1 (January, 1979). , Inside the Black Box: Technology and Economics,

Cambridge University Press, Cambridge, 1982.

Rosenberger, N.R. (ed.), Japanese Sense of Self, Cambridge

University Press, Cambridge, 1992.

Rule, J., 'The Property of Skill in the Period of Manufacture', Joyce (ed.), The Historical Meanings of Work.

Schwarz, L.D., 'Income Distribution and Social Structure in London in the Late Eighteenth Century', Economic History Review, 32 (1979). 
Smith, T.C., The Agrarian Origins of Modern Japan, Stanford

University Press, Stanford, 1959. , Native Sources of Japanese Industrialization, 1750-1920, University of California Press, Berkeley, 1988.

Thompson, E.P., Customs in Common, Merlin Press, London, 1991. Thompson, P., 'Playing at Being Skilled Men: Factory Culture and

Pride in Work Skills among Coventry Car Workers', Social History, 13 (1988). , The Nature of Work, Macmillan, London, 1989 (first published in 1983).

Tucker, M.E., Moral and Spiritual Cultivation in Japanese

Neo-Confucianism: The Life and Thought of Kaibara Ekken (1630-1714), SUNY (State University of New York) Press, Buffalo, 1990.

Turner, H.A., Trade Union Growth: Structure and Policy, George Allen and Unwin, London, 1962.

Vlastos, S., Peasant Protests and Uprisings in Tokugawa Japan,

University of California Press, Berkeley, 1986.

Wagatsuma Hiroshi, 'Status and Role Behavior in Changing Japan:

Psychocultural Continuities', G.A. De Vos, Socialization for

Achievement: Essays on the Cultural Psychology of the

Japanese, University of California Press, Berkeley, 1973.

Wall, R. and Saitō Osamu (eds.), The Economic and Social Aspects

of the Family Life-cycle: Europe and Japan, Traditional and Modern, Cambridge University Press, Cambridge, forthcoming.

Wallman, S. (ed.), Social Anthropology of Work, Academic Press, London, 1979.

Walthall, A. (ed. \& tr.), Peasant Uprisings in Japan, University of

Chicago Press, Chicago, 1991.

Weber, M., 'The Religions of Asia', W.G. Runciman (ed.), Weber: 
Selections in translation, Cambridge University Press, Cambridge, 1978. The article was translated from Gesammelte Aufsatze zur Religionssoziologie, 2nd edn, Tubingen, 1923, II, s. 363-78.

Wood, S. (ed.), The degradation of work?: Skill, De-skilling and the Labour Process, Hutchinson, London, 1982.

Yasunaga Toshinobu, Andō Shōeki: Social and Ecological

Philosopher of Eighteenth-Century Japan, Weatherhill, New York, 1992.

\section{Encyclopedias, dictionaries}

Aoki Kazuo, et. al. (eds.), Nihonshi Daijiten, Heibonsha, Tōkyō, 1992-1994.

Hepburn, J.C., Waei Gorin Shüsei, American Presbyterian Mission Press, Shanghai, 1867, 1872.

Kindaichi Kyōsuke, et. al. (eds.), Nihon Kokugo Daijiten, Shōgakukan, Tōkyō, 1972-1976.

Kokushi Daijiten Henshū Iinkai (ed.), Kokushi Daijiten, Yoshikawa Kōbunkan, Tōkyō, 1972-1994.

Maeda Isamu (ed.), Edogo no Jiten (Kōdansha Gakujutsu Bunko), Kōdansha, Tōkyo, 1991 (first published in 1979).

Morrison, R., A Dictionary of Chinese Language, Black, Parbury, and Allen, London, 1822.

Niimura Izuru (ed.), Köjien third and revised edition, Iwanami Shoten, Tōkyō, 1983.

Takenaka Yasukazu, 'Sengo ni okeru Sekimon Shingaku no Bunken to Kenkyū', Takenaka, Sekimon Shingaku no Keizai Shisō,

A Supplementary.

Tsuchiya Tadao, et. al. (eds.), Nippo Jisho (Japanese-Portuguese

Dictionary - translated into contemporary Japanese language 
from Vocabvlario Da Lingoa De Iapam: com a declaracao em Portugues of 1603), Iwanami Shoten, Tōkyō, 1980.

Yagi Shigeki, 'Ninomiya Sontoku Kankei Shuyō Bunken', Nagasawa

Motoo (ed.), Ninomiya Sontoku no Subete, Shin Jinbutsu Öraisha, 1993.

\section{Archives consulted}

Hōtoku Hakubutsukan, Odawara

Keiō Gijuku Daigaku, Tōkyō

Keizai Kenkyūsho, Hitotsubashi Daigaku, Tōkyō

Kokuritsu Kokkai Toshokan, Tōkyō

Meirinsha (Shingaku), Kyōto

Sekimon Shingakukai, Tōkyō 